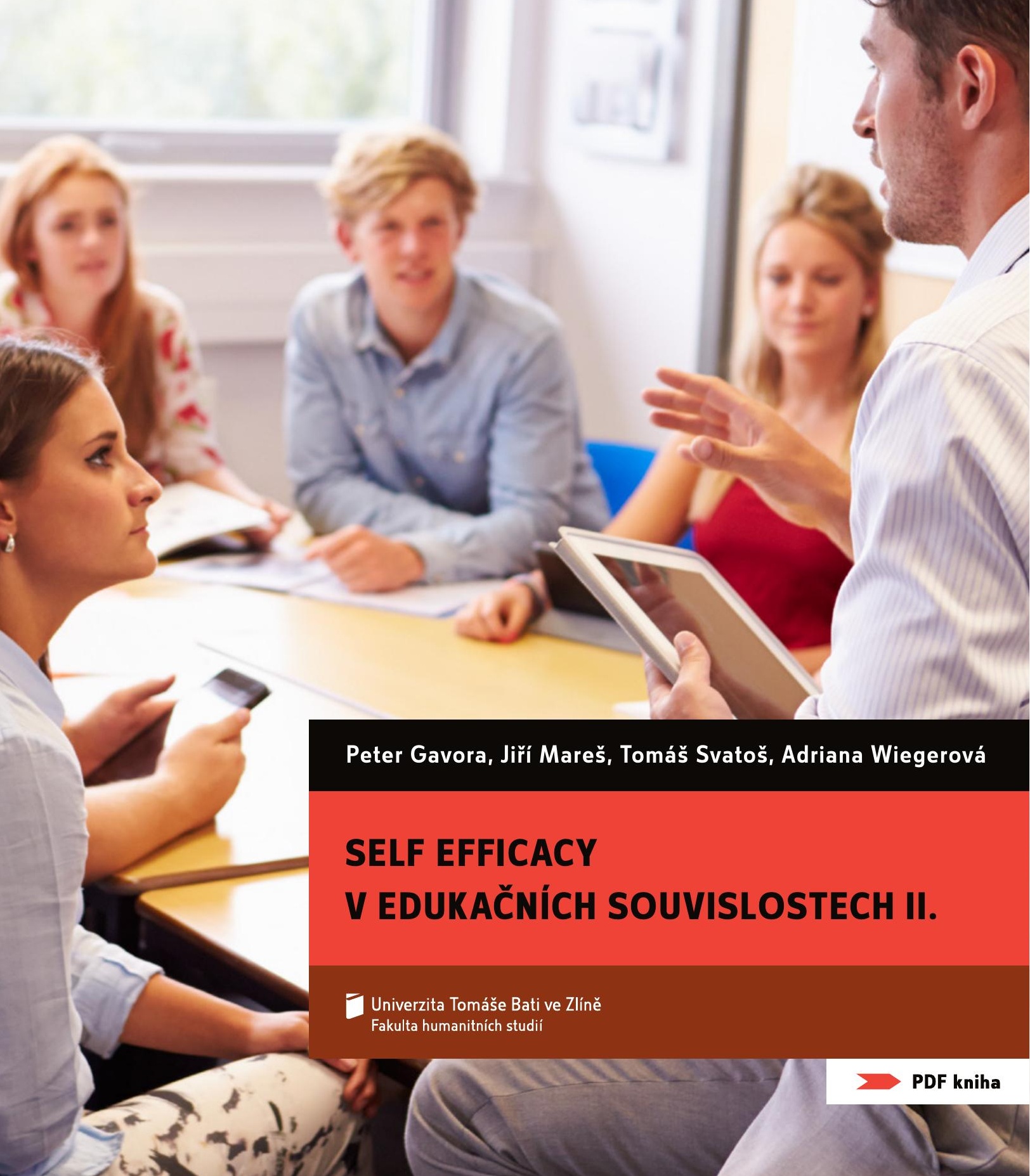



Univerzita Tomáše Bati
Fakulta humanitních studií 

Peter Gavora, Jiři Mareš, Tomáš Svatoš, Adriana Wiegerová

\section{SELF EFFICACY V EDUKAČNÍCH SOUVISLOSTECH II.}


KATALOGIZACE V KNIZE - NÁRODNÍ KNIHOVNA ČR

Gavora, Peter, 1942-

Self efficacy v edukačních souvislostech II. / Peter Gavora, Jiří Mareš, Tomáš Svatoš, Adriana Wiegerová. -- Pořadí vydání: první. -- Ve Zlíně : Univerzita Tomáše Bati, Fakulta humanitních studií, 2020. -- 1 online zdroj. -- (Pedagogika)

Anglické resumé

Obsahuje bibliografii a rejstř́ík

ISBN 978-80-7454-949-6 (online; pdf)

* $377.8 * 377 * 37.091 .321 * 37.012 *(048.8: 082)$

- vzdělávání učitelů

- profesní prríprava

- pedagogické dovednosti

- pedagogický výzkum

- self-efficacy

- kolektivní monografie

37.09 - Organizace výuky a vzdělávání [22]

Recenzenti: prof. PhDr. Hana Lukášová, CSc.

prof. PhDr. Jan Průcha, DrSc.

Dr.h.c. prof. PhDr. Miron Zelina, DrSc.

Peter Gavora - kapitoly: 6.1, 7.1

Jiř́i Mareš - kapitoly: 1, 2, 3

Tomáš Svatoš - kapitoly: 4, 5.1, 6.2, 7.2

Adriana Wiegerová - kapitoly: 5.2, 7.1, editoring

(C) Peter Gavora, Jiří Mareš, Tomáš Svatoš, Adriana Wiegerová, 2020

(C) Univerzita Tomáše Bati ve Zlíně, 2020

FAKULTA HUMANITNICH STUDIII/EDICE PEDAGOGIKA

ISBN 978-80-7454-949-6 


\section{OBSAH}

PŘEDMLUVA

ÚVOD

1/ STRUČNÁ HISTORIE SOCIÁLNĚ KOGNITIVNÍ TEORIE

$\begin{array}{ll}1.1 \text { Pojem self efficacy } & 17\end{array}$

1.2 Vztah vnímané vlastní zdatnosti k př́íbuzným pojmům 20

2/ VNÍMANÁ VLASTNÍ ZDATNOST VE ŠKOLNÍM KONTEXTU 25

2.1 Diagnostikování vnímané vlastní zdatnosti 29

3/ TRENDY A MOŽNÝ BUDOUCÍ VÝVOJ VE ZKOUMÁNí SELF-EFFICACY

4/ VÝZKUMY SELF-EFFICACY A PREGRADUÁLNÍ VZDĚLÁVÁNÍ UČITELŮ

5/ SELF-EFFICACY V GENEZI PEDAGOGICKÉHO PROFESNÍHO VÝVOJE

5.1 Pregraduální vzdělávání, jeho etapy a gradace

5.2 Význam pedagogické praxe v profesním vývoji budoucího učitele 


\section{6/ PŘíKLADY VÝZKUMNÝCH POSTUPŮ SELF-EFFICACY V PREGRADUÁLNÍM VZDĚLÁVÁNí}

6.1 Kvantitativní přístup ke zkoumání self-efficacy učitele: metodologická reflexe

6.1.1 Př́ístup ke zkoumání self-efficacy učitele 62

6.1.2 Klíčové postavení teorie 63

6.1.3 Interpretace teorie 64

6.1.4 Induktivní a deduktivní strategie při konstrukci dotazníků $\quad 66$

6.1.5 Forma položek v dotazníku 68

6.2 Kvalitativní a smíšené přístupy ve výzkumech self efficacy 70

6.2.1 Charakteristika interview v ohniskové skupině - focus group 71

\section{7/ VÝZKUMY SELF-EFFICACY STUDENTŮ UČITELSTVÍ} V ADAPTAČNÍ ETAPĚ STUDIA $\quad 79$

7.1 Zkoumání self-efficacy u budoucích učitelů mateřských škol $\quad 79$

$\begin{array}{lll}7.1 .1 & \text { Zjišt’ování self-efficacy učitelů } & 79\end{array}$

$\begin{array}{lll}\text { 7.1.2 Metodologie výzkumu } & 80\end{array}$

7.2 Self efficacy studentů učitelství vybraných aprobací 90

7.2.1 Cíle šetření, metodologie výzkumu, participanti výzkumu 92

7.2.2 Interpretace výzkumných zjištění a dílčí komentáře ve výzkumu self-efficacy v adaptační etapě studia 97

7.2.3 Závěrečné ohlédnutí 106

ZÁVĚR

$\begin{array}{ll}\text { SUMMARY } & 113\end{array}$

$\begin{array}{lr}\text { LITERATURA } & 115\end{array}$

$\begin{array}{ll}\text { REJSTŘÍK } & 129\end{array}$ 
Obr. 1: Podrobněji rozvedený Bandurův model reciproční interakce tří typů procesů

Obr. 2: Bandurovo pojetí aktérství člověka

Obr. 3: Rozdíly mezi očekáváním, které je spojeno s vnímanou vlastní zdatností a očekáváním spojeným s výsledkem chování

Obr. 4: Vnímaná vlastní zdatnost jedince, její zdroje a způsob navození

Obr. 5: Vztah motivačních typů k vnímané vlastní zdatnosti člověka

Obr. 6: Představa profesionalizačních etap uvnitř pregraduálního vzdělávání

Obr. 7: Typy kvalitativních šetření a konkrétních metod

Obr. 8: Průměry jednotlivých dimenzí v dotazníku SEPRES v semestrech bakalářského studijního programu

Tab. 2.1: Dotazníky zjišt'ující specifické typy vnímané vlastní zdatnosti u lidí

Tab. 5.1: Náčrt profesionalizačních etap a klíčové zdroje self-efficacy

Tab. 6.1: Výčet a charakteristika některých metod kvalitativní analýzy dat

Tab. 6.2: Procedura focus group a její základní charakteristiky

Tab. 7.1: Znění položek, faktory a faktorové zátěže dotazníku SEPRES

Tab. 7.2: Vzájemné korelace mezi dimenzemi dotazníku SEPRES

Tab. 7.3: Deskriptivní data dotazníku SEPRES

Tab. 7.4: Položky dotazníku SEPRES s nejvyšším a nejnižším průměrem

Tab. 7.5: Procedura focus group a její fáze

Tab. 7.6: Oblast praxe participantů a studované obory podle pohlaví

Tab. 7.7: Úrovně pochopení a uchopení konceptu self-efficacy začínajícími studenty učitelství

Graf 1: Odpovědi začínajících studentů učitelství na čtyři otázky týkající se selfefficacy (Linke, 2013) 



\section{PřEDMLUVA}

V roce 2011 se setkal tým česko-slovenských odborníků na tvorbě publikace Self-efficacy v edukačných súvislostiach, kterou vydalo Slovenské pedagogické nakladatel'stvo v Bratislave, s dotací Univerzity Tomáše Bati ve Zlíně. Publikace byla tehdy zpracována $v$ češtině i slovenštině. $V$ době tvorby jednotlivých kapitol v této kolektivní monografii bylo téma self efficacy v česko-slovenském kontextu poměrně novým tématem. Jeho etablování do odborného diskurzu již v této době potvrzují bohaté citační odkazy. Publikace se ocitla i jako odkaz na Wikipedii, což jen potvrzuje její hojné využívání.

Od roku 2012 se kolem tématu self efficacy kreovaly výzkumy, které je možné najít v předních žurnálech doma i v zahraničí. Téma je zdrojem zajímavých vystoupení na mezinárodních konferencích, či sympoziích.

Jenomže ani autoři původní publikace nechtěli zůstat v průběhu let nečinní. A tak po několika diskusích vzniká volné, tedy druhé, pokračování publikace se stejnojmenným názvem, značeným II., ale tentokrát publikované pouze v českém jazyce. Původní autorský tým se zúžil, ale obsah monografie má ambici prohloubit poznatky v oblasti self efficacy jak v teoretické, tak v empirické rovině.

Především šestá kapitola vznikala tak, že se původně na jejím vzniku měl podílet Marek Linke. Jeho životní situace, jak to už bývá, se změnila, a tak se ujal kapitolu dokončit jeho školitel magisterské práce. Markovi touto cestou chceme poděkovat za jeho př́nos pro téma self efficacy, a také za jeho prezentaci na různých studentských konferencích.

Naše poděkování také patří recenzentům monografie. V první řadě paní prof. Haně Lukášové, která přijala roli vědeckého garanta, ale také prof. Janovi Průchovi a prof. Mironu Zelinovi, kteř́ recenzovali i předcházející publikaci na toto téma. 
Těší nás, že se téma self efficacy stává výzkumně zajímavé i pro studenty vysokých škol, protože si ho volí jako koncept pro tvorbu své diplomové práce, ale také je to (jak se zdá) zajímavé téma pro nadějné začínající výzkumníky, protože se ocitá i v zorném poli zájmu studentů doktorských studijních programů.

Právě proto, že jde o téma výzkumně zajímavé a nekončící, jsme rádi, že jsme jej mohli otevrrít i pro pedagogickou komunitu a věříme, že i tato část příspěvku k tématu bude přijata jako dílo, které otevírá nové pohledy na výzkumy self efficacy a pobízí k metodologickým diskusím i díky prezentaci metodologických př́istupů k výzkumům o učitelích. 


\section{ÚVOD}

Kolektivní monografie, kterou předkládáme čtenářům, volně navazuje na předchozí monografii (Wiegerová, et. al., 2012). Opírá se o zahraniční publikace (převážně časopisecké), které vyšly v letech 2010-2020. Soustřed'uje se na pedagogické aplikace pojmu self efficacy na úrovni základních a středních škol, a to v rámci tzv. naukových předmětů. $Z$ vysokoškolské úrovně studia jsme pro tento přehled vybrali pouze téma př́ípravy budoucích učitelů.

Přitom jsme si vědomi, že aplikační pole pojmu self efficacy se v posledních letech rozšíríilo do přípravy budoucích jazykovědců, inženýrů, programátorů, manažerů, přírodovědců, lékařů, nelékařských zdravotnických pracovníků, sportovců, do edukace pacientů, do podnikového vzdělávání. Ty to aplikace necháváme stranou, nebot' by si vyžádaly celou knižní publikaci.

V teoretických kapitolách 1. - 3, se čtenáři mohu dozvědět, kde se aktuální teoretické poznání self efficacy především z mezinárodní perspektivy nachází, i jaké jsou možnosti jeho dalšího rozvíjení. Dủležitou proměnnou teoretických částí je mapování výzkumů ve vymezeném tématu, a také hlubší poznání zázemí vzniku konceptu self efficacy, jako i dalších, například agendy.

Důležitou součástí monografie je ale prezentace konkrétních výzkumů, které vznikaly v posledních pěti letech $v$ oblasti zkoumání self efficacy budoucích učitelů, tedy studentů, kteří se připravují na své povolání a jsou v této době na startu své profesní dráhy. Především diskuse k metodologickým postupům v těchto výzkumech může být pro čtenáře zajímavá. Ukazuje totiž na pestré možnosti, které se nabízí k poznání tohoto fenoménu. Čtenáři mohou nahlédnout do tvorby jednoho dotazníku na zjišt’ování self efficacy, který vznikl specificky pro skupinu budoucích učitelů mateřských škol, ale také mohou sledovat možnosti výzkumného posunu k spíše kvalitativnímu designu přes využití práce v ohniskových skupinách. 
Kapitoly ukazují na širokou škálu výzkumných možností jak v kvantitativní, tak v kvalitativní rovině. Důležitou součástí vnímání a hodnocení self efficacy u studentů učitelských programů je také zachycení jejich profesního vývoje, ve kterém pomáhají kromě předmětů teoretické přípravy, také smysluplné koncepce pedagogických praxí na jednotlivých fakultách, připravujících budoucí učitele.

Věříme, že publikace si tak, jako její starší předchůdkyně, najde své čtenářské zázemí a bude přínosem pro rozvoj poznání, ale také diskusí v oblasti sledování self efficacy učitelů na jednotlivých stupních škol. 


\section{$1 /$ \\ STRUČNÁ HISTORIE SOCIÁLNĚ KOGNITIVNÍ TEORIE}

Myšlenka sociálních vlivů na lidské učení (včetně učení napodobováním druhých osob) má své kořeny už ve 40. letech 20. století v pracích amerických psychologů N.E. Millera a J. Dollarda. V šedesátých letech minulého století ji při výzkumech agresivního chování dětí rozvedl kanadský psycholog ukrajiného původu A. Bandura do podoby sociálně-kognitivní teorie učení. Ukázal důležitou roli modelu, vzoru při učení se novému chování. V roce 1977 vydal článek, v němž navíc shrnul výchozí předpoklady teorie self efficacy. V článku postuloval tezi, že je to právě self efficacy, proměnná, která hraje rozhodující roli ve změně chování člověka.

V roce 1986 vydal Bandura další knihu, v níž svou teorii ze šedesátých let rozšířil a zobecnil. Aby ji odlišil od oné původní, přejmenoval ji na sociálně kognitivní teorii (bez konkretizace na učení). V jakém vztahu jsou teorie self efficacy a sociálně kognitivní teorie? Sociálně kognitivní teorie je nadřazená; integruje v sobě self efficacy jako svou klíčovou proměnnou (Lippke, 2017).

Ústředním myšlenkou sociálně kognitivní teorie je, že existují tři základní faktory, které spolu interagují navzájem na sebe působí. Pro označení tohoto vzájemného působení se v literatuře používají výrazy typu: reciproční interakce, triadická reciprocita či reciproční determinismus a jsou chápana jako synonyma. Determinismus označuje výsledný efekt celého souboru vzájemně propojených vlivů; je zde chápán spíše pravděpodobnostně než lineárně. Zmíněné tři faktory jsou: 1. chování člověka, 2. osoba a její charakteristiky, 3. vnější prostředí. Nemají stejnou váhu, ale stává se, že v určitém časovém období vystoupí jeden ze tří faktorů do popředí výrazněji (Janoušek, 1992).

V literatuře nezůstává však jenom u samotné triády, ale v poslední době se objevují snahy jednotlivé složky těchto faktorů podrobněji specifikovat (viz obr. 1). 


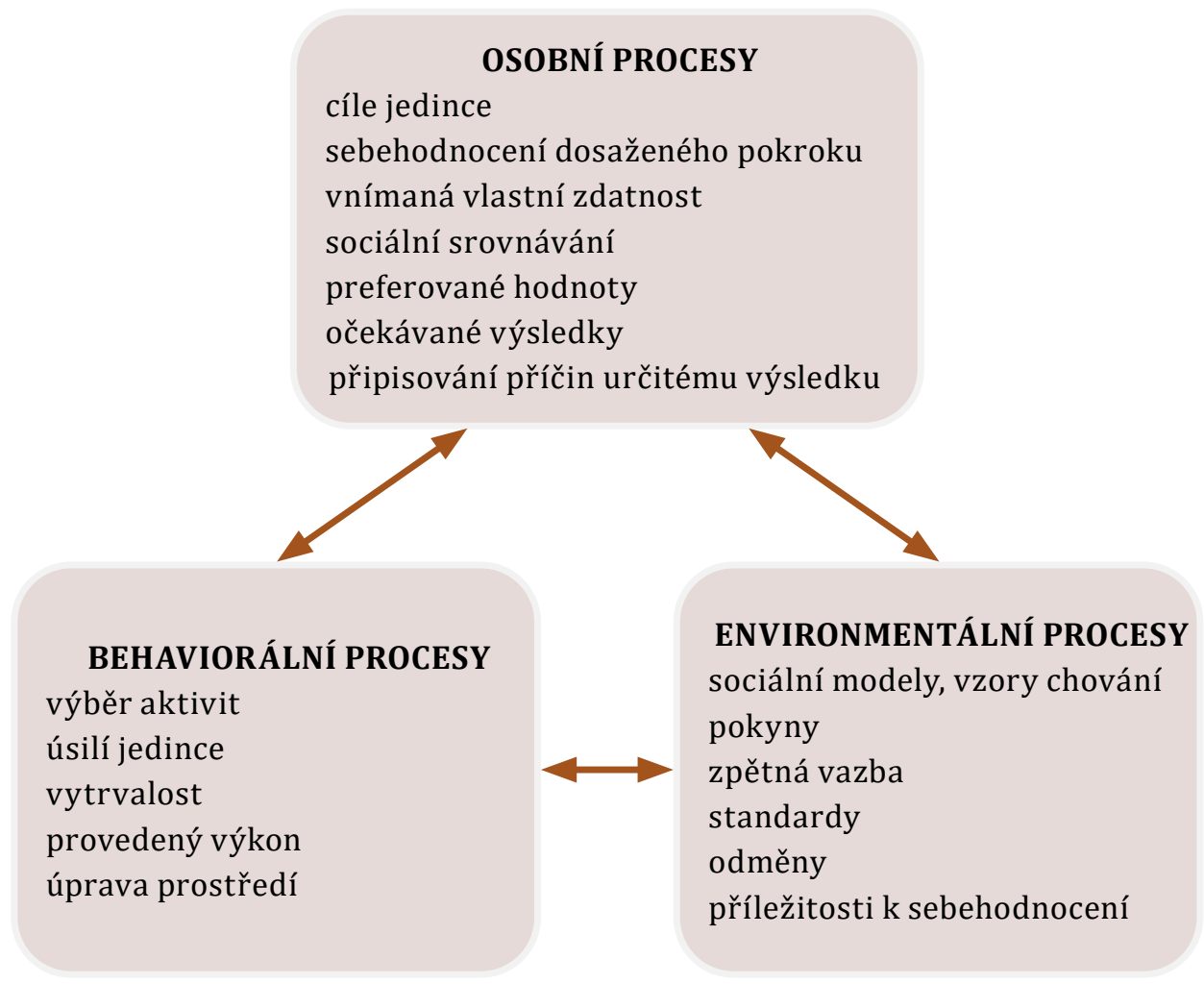

Obr. 1: Podrobněji rozvedený Bandurův model reciproční interakce tří typů procesů (modifikovaně podle Schunk, \& DiBenedetto, 2020, s. 3)

Kolem roku 2000 obohatil Bandura svoji sociálně kognitivní teorii o pojem aktérství. Jedincovým aktérstvím rozumí Bandura jedincovu schopnost představit si jedinečné události a různé nové způsoby svého jednání; vybrat si jednu možnost a uskutečnit ji (modifikovaně podle Bandura, 2001). Aktérství zahrnuje složitý komplex procesů, zejména: intrapersonální kognitivní zpracování informací, rozvažování, přijetí rozhodnutí, a to vše je motivováno snahou dospět ke konkrétním výsledkům. Podle Bandury naše přání formují naše záměry aktivně jednat, předcházejí tedy chování zaměřenému na dosažení cíle. Přání dosáhnout potřebného cíle jedince motivuje k tomu, aby jeho aktivity dospěly až k žádoucímu vyústění.

Přitom aktérství může nabývat (podle počtu aktérů a jejich funkce) tří různých podob: individuální, kolektivní a zástupné. Při individuálním aktérství aktivity provádí jedinec sám, při kolektivním je aktérem skupina, tým, příp. celá organizace. 
Zajímavým případem je tzv. zástupné aktérství (proxy agency). Člověk prosí, přesvědčuje, naléhá, aby za něj převzal aktivitu někdo jiný, schopnější a odborně zdatný. Zmocňuje ho, aby jednal jeho jménem a zajistil mu dosažení žádoucího výsledku. Každá z těchto tři podob nabízí jiný způsob, jak dosáhnout cíle. $\mathrm{V}$ běžném životě využíváme všechny tři podoby aktérství, byt' v různých proporcích.

Celkový pohled na Bandurovo pojetí aktérství člověka přináší obr. 2.

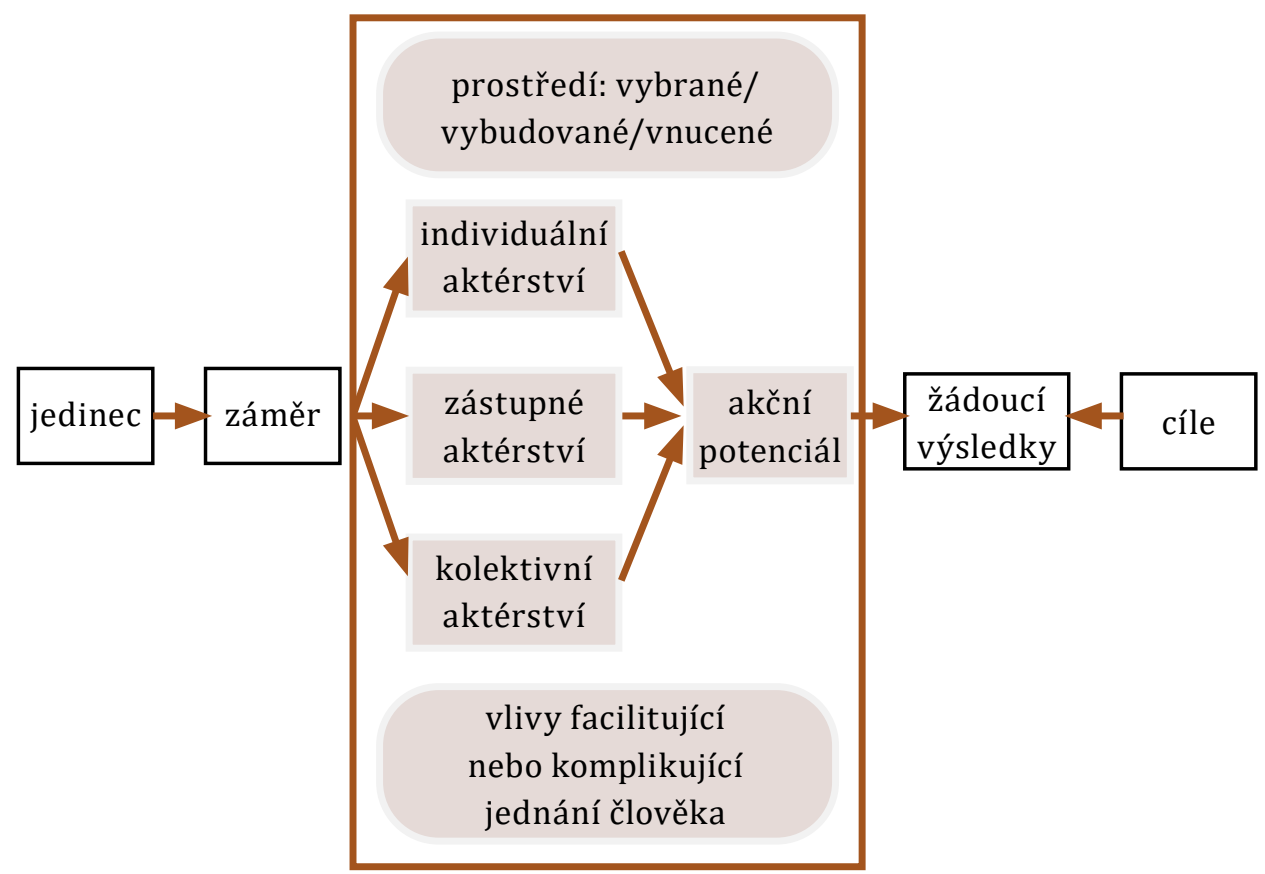

Obr. 2: Bandurovo pojetí aktérství člověka (Bergman, Bergman, \& Thather, 2019, s. 3)

$\mathrm{V}$ roce 2006 A. Bandura rozvedl zejména případ individuálního aktérství. Jedinec je chápán jako aktér dění, což znamená, že promyšleně ovlivňuje své chování, své fungování ve společnosti a nemá pouze trpně přijímat životní okolnosti. Je proaktivním, sebeorganizujícím, sebereflektujícím a autoregulujícím se tvorem. Není pouhým divákem svého života. Podle Bandury se lidské aktérství vyznačuje čtyřmi charakteristikami (Bandura, 2006 a).

První je záměrnost (intencionality). Člověk má řadu cílů, plánuje si svoji činnost a promýšlí postupy, strategie, jak cílů dosáhnout. Současně platí, že aktér nežije sám, nebot' realizaci jeho záměrů ovlivňují (at' už pozitivně nebo negativně) ostatní 
lidé. Pokud se jedná o aktérství skupiny, o kolektivní usilování, je třeba, aby se členové shodli na společném záměru, přijali ho za vlastní, naplánovali si postup a dobře sladili svoje usilování.

Druhou charakteristikou je prozíravost, předvídavost (forethought). Představuje časový rozměr aktérství, snahu uvažovat s ohledem na budoucí vývoj. Lidé si nejen stanovují cíle, ale uvažují o pravděpodobnosti různých výsledků svého snažení. Promýšlí další vývoj, vizualizují si scénáře budoucnosti; to vše jim dává určitá vodítka a motivuje je k určitým způsobům chování. Očekávané budoucí výsledky tedy vstupují do současných aktivit lidí a podporují cílevědomé a prozíravé chování. $\mathrm{Z}$ dlouhodobé perspektivy dává předvídavost směr lidskému snažení, podílí se na konzistentnosti rozhodování a chování, vede k hlubším úvahám o smyslu celého života.

Třetí je reagování na sebe sama, sebe-reaktivita (self reactiveness). Aktér nesedí s rukama v klíně, nečeká, až se mu občas nějaká činnost povede, až se dostaví první výsledky. Monitoruje své chování, snaží se poučit z chyb, hledá lepší postupy, motivuje sám sebe, aby vytrval v dosavadním směřování, příp. aby vyvinul větší úsilí. Řídí sám sebe, snaží se sám zlepšovat, propojuje své úvahy s aktivním jednáním.

Čtvrtou je sebe-reflektivita (self reflectiveness). Lidé nejsou jenom stále jednajícími aktéry, ale přemýšlejí o svém chování, uvažují sami o sobě, o svých vlastnostech, kontrolují a hodnotí sami sebe. Vnímají a posuzují svoji zdatnost v různých životních i pracovních situacích. Je-li třeba, korigují své chování a čas od času i poopraví pohled na sebe samotného. Metakognitivní úvahy, reflektování kvality svých myšlenek a činů patří k důležitým charakteristikám aktérství.

Zatím jsme mluvili převážně o aktérovi samotném. Ten však žije a pracuje $\mathrm{v}$ určitém prostředí, jedná v určitých sociálních podmínkách. Jinak řečeno aktér funguje v konkrétním př́rodním, sociálním, kulturním prostředí. Tento kontext mu skýtá určité př́ležitosti k jednání, ale současně přináší i určitá omezení. Bandura rozlišil tři rozdílné typy prostředí: prostředí, které si jedinec vybral (selected environment), prostředí, které si vytvořil, vybudoval (constructed environment) a konečně prostředí, které mu bylo vnuceno druhými lidmi (imposed environment). Každá z těchto možností otevírá odlišný prostor pro jednání člověka. 
Pojem self efficacy není snad ný pojem ani po věcné, ani po terminologické stránce. Podle Bandury (1994, s. 71) představuje self efficacy (tento pojem překládáme ${ }^{1}$ jako vnímaná vlastní zdatnost) přesvědčení lidí (beliefs) o svých schopnostech/ způsobilostech (capabilities) dosahovat určitých úrovní výkonnosti. Tyto výkonnostní úrovně pak mají vliv na události, jež zase ovlivňují jejich životy. Přesvědčení o vnímané vlastní zdatnosti určuje, jak se lidé cítí, jak myslí, jak sami sebe motivují a jak se chovají. Vnímané přesvědčení mívá rozmanité důsledky a podílejí se na tom čtyři hlavní procesy: kognitivní, motivační, afektivní a selektivní.

Bandura ke své definici dodává i praktické důsledky, které z ní plynou. Jedinec, který vnímá, že je velmi zdatný, si věří a přistupuje i k obtížným úkolům jako k výzvě, kterou je třeba přijmout, nikoli jako k hrozbě, jíž je třeba se vyhnout. Stanovuje si náročné cíle a při jejich dosahování projevuje odhodlání a vytrvalost. Nezlomí ho neúspěchy, rychle se z nich zotavuje. Svůj neúspěch připisuje bud' nedostatečnému úsilí anebo nedostatečným schopnostem. Obojí lze z jeho pohledu napravit. Takový přístup k úkolům mu přináší pocit úspěšnosti, snižení stresu a posílení zaujetí k prováděné činnosti.

Naopak jedinec, který si uvědomuje, že je málo zdatný, pochybuje o svých schopnostech; vyhýbá se úkolům, které považuje za obtížné; vnímá je jako hrozbu, jež mohou ukázat na jeho nedostatečnost. Takový jedinec má nízké ambice a při řešení problémů se zabývá svými slabinami a vnějšími překážkami, které mu znemožnují podat dobrý výkon. Uvažuje o negativních důsledcích toho všeho, místo aby se soustředil na řešení problémů. Už při prvních obtížích ochabuje ve svém úsilí, po několika neúspěšných pokusech se vzdává. Svým selháním a nezdary se pak dlouze obírá. Nedostatečný výkon spojuje se svými malými schopnostmi a s tím se (podle jeho mínění) nedá nic dělat. Jeho výkon je provázen pocity stresu; zažívá i stavy deprese (modifikovaně podle Bandura, 1994, s. 71).

Dva teoretické modely vnímané vlastní zdatnosti. První model z konce sedmdesátých let přibližuje Bandurovy úvahy o vnímané vlastní zdatnosti člověka. Tehdy soustředil svoji pozornost jen na dvě proměnné: vnímanou vlastní zdatnost a očekávání člověka (obr. 3).

1 Z terminologického pohledu činí překlad do češtiny značné problémy. Setkáváme se s výrazy „sebeuplatnění“ (Janoušek), „,vnímaná sebe-výkonnost“ (Nakonečný), „vnímaná vlastní účinnost“ (Gillernová, Kebza, Rymeš et al.), „vnímaná osobní účinnost“ (Hoskovcová), „osobní zdatnost“ (Mareš, Gavora; Smékal), „vnímaná vlastní zdatnost“ (Mareš, 2013). V této práci budeme používat posledně uvedený termín. 


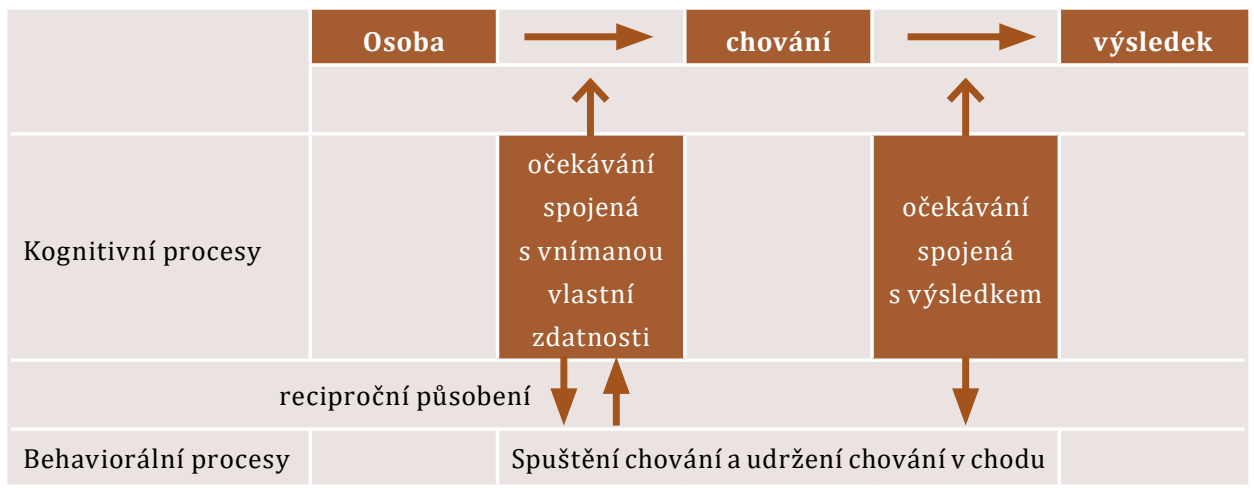

Obr. 3: Rozdíly mezi očekáváním, které je spojeno s vnímanou vlastní zdatností a očekáváním spojeným s výsledkem chování (modifikovaně podle Bandura, 1977, s. 193 a Lippke, 2016, s. 2)

V novějších pracích přibyly do modelu další proměnné: cíle, zprostředkující vlivy a také překážky.

Druhý model přibližuje mechanismy působení a v jeho středu je vnímaná vlastní zdatnost člověka. Na jedné straně jsou uvedeny zpo̊soby navození změn v lidském chování a zdroje, z nichž může jedinec čerpat, na straně druhé figurují výsledky snah o změnu jedincova dosavadního chování (viz obr. 4)

Dimenze vnímané vlastní zdatnosti. Vlastní zdatnost člověka není jedna homogenní entita, ale můžeme v ní odlišit řadu dimenzí (Redmond, \& Slaugenhoup, 2016):

- míru zdatnosti, s jejíž pomocí lze charakterizovat úroveň obtížnosti úkolu, na jehož řešení si jedinec troufne (úkol snadný, středně těžký, velmi obtížný)

- vnitřní jistota o své zdatnosti; vnitřní přesvědčení jedince, že je v jeho silách úkoly různé obtížnosti zvládnout

- obecnost své zdatnosti říká, nakolik se vnímaná zdatnost týká rozdílných typů úkolů, nakolik je trans-situační.

Až dosud jsme mluvili o vnímané vlastní zdatnosti jako o důležité charakteristice jedince samotného. Bandura si začátkem devadesátých let 20. století uvědomil, že tuto vnímanou zdatnost lze přiřadit i sociální skupině, pracovnímu týmu, celé organizaci, celým populacím; ve škole pak třeba učitelskému sboru či školní třídě. Zvolil pro ni označení vnímaná zdatnost kolektivu² (perceived collective efficacy).

2 Také u tohoto odborného termínu nepanuje shoda v tom, jak ho překládat do češtiny. Objevují se mj. tyto verze: „kolektivní uplatnění“ (Janoušek), „Vnímané kolektivní sebeuplatnění“ (Výrost, Slaměník), „kolektivní vnímaná účinnost“ (Gillernová a kol.). 


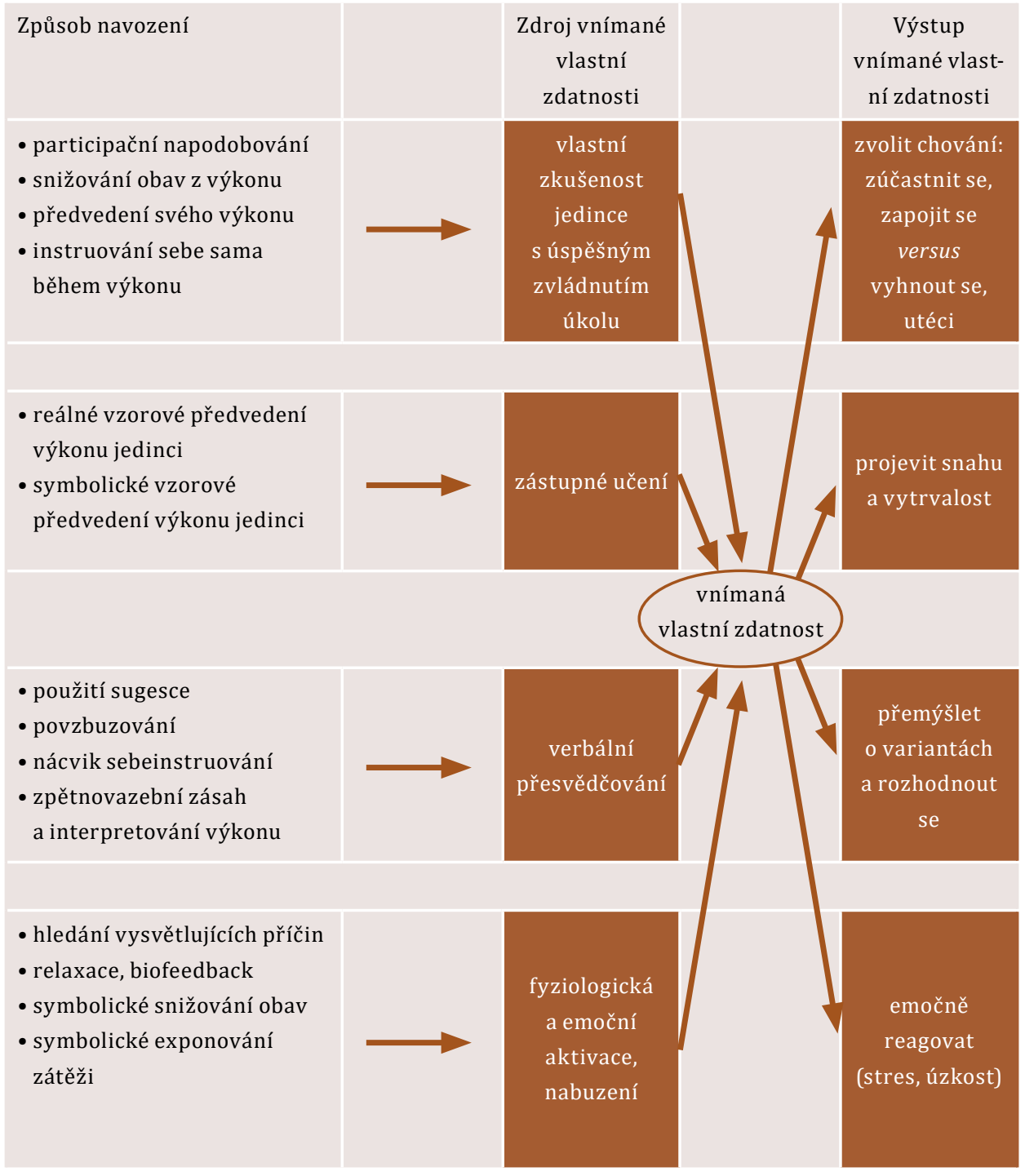

Obr. 4: Vnímaná vlastní zdatnost jedince, její zdroje a způsob navození (modifikovaně podle Bandura, 1977, s. 195 a Reeve, 2014, s. 277) 
Definoval ji jako proměnnou, která ovlivňuje to, co se lidé rozhodnou dělat jako skupina, kolik úsilí do toho vloží; jejich sílu vytrvat, nevzdávat to, když skupinové úsilí nedosáhne hned žádoucích výsledků (Bandura, 1982, s. 148). Později tuto definici doplnil: jde o skupinové přesvědčení o skupinové schopnosti/způsobilosti, která je nutná k organizování a provedení aktivit, jež vedou k určitému výsledku (Bandura, 1997, s. 477).

Vnímaná zdatnost kolektivu je skupinovou charakteristikou. To však neznamená, že je homogenním celkem, nebot' členové dané skupiny obvykle vnímají „svoji skupinu“ poněkud rozdílně. Proto odborníci rozlišují tři úrovně: 1 . vnímanou vlastní zdatnost každého člena skupiny jako jednotlivce, 2 . vnímanou zdatnost „své skupiny“, svého kolektivu každým členem skupiny jako jednotlivcem, 3. souhrnnou zdatnost celé skupiny, celého kolektivu z pohledu všech členů dané skupiny. Výzkumy naznačují, že čím větší jsou rozdíly mezi členy skupiny v názorech na celkovou zdatnost dané skupiny, tím je obvykle souhrnná zdatnost menší.

I v České republice se pozvolna rozbíhá výzkum vnímané zdatnosti kolektivu (Vozková, 2018), zejména pak učitelské kolektivní zdatnosti.

Zbývá dodat důležité upozornění: jak individuální vnímaná zdatnost jednotlivce, tak vnímaná zdatnost kolektivu není statická proměnná, není přisouzena jednotlivci či skupině jednou provždy. Průběžně se aktualizuje (updating), aby odpovídala jednak měnícím se podmínkám, v nichž se člověk/skupina rozhoduje pro určité jednání, jednak měnící se úspěšnosti takového jednání a konečně měnícímu se člověku/skupině v čase.

V celé předchozí části výkladu jsme se věnovali vnímané zdatnosti člověka samotného. Nyní se podíváme na shody a rozdíly mezi vnímanou zdatností a blízkými psychologickými pojmy.

\section{2}

\section{Vztah vnímané vlastní zdatnosti k příbuzným pojmům}

Sebepojetí člověka. První důkladnou definici sebepojetí člověka předložil Shavelson se spolupracovníky. Říká se v ní: sebepojetím člověka rozumíme individuální vnímaní sebe sama. Toto vnímání má sedm základních charakteristik, je: 1. organizované, 2. mnohostranné, 3. hierarchicky uspořádané, 4. stabilní (pak jde o obecné pojetí sebe sama) či nestabilní (jde o pojetí vázané na měnící se situace), 5. vývojové, 6. popisné a hodnotící, 7. odlišitelné od ostatních konstruktů (Shavelson, \& Hubner, Stanton,1976, s. 435).

Čím se liší sebepojetí člověka od vnímané vlastní zdatnosti? Z historického pohledu je sebepojetí starší odborný pojem (jeho počátky nalezneme už u Williama Jamese 
z 90. letech 19. století) zatímco vnímaná zdatnost je pojem novější (Bandurův pojem je z konce 70 . let 20. století). Předpokládalo se, že jeden z rozdílů mezi oběma pojmy spočívá v tom, že sebepojetí člověka je obecná, globální proměnná, zatímco vnímaná vlastní zdatnost je proměnná doménově/tematicky specifická, vázaná na konkrétní úkoly (Bandura, 1986). To už dávno neplatí, nebot' už existují výzkumy, které sledují sebepojetí lidí ve vztahu ke konkrétním doménám anebo zase dotazníky zjišťující obecnou, globálně vnímanou zdatnost (např. dotazník Schwarzera a Jeruzalema).

Podle výzkumného týmu (Marsh, Pekrun, \& Parker et al., 2019) však existují tři výrazné rozdíly mezi sebepojetím člověka a jeho vnímanou vlastní zdatností. První rozdíl spočívá v tom, že sebepojetí dovoluje předpovídat budoucí chování člověka a výsledky, k nimž asi povede, ale vychází do značné míry z chování tohoto člověka v minulosti, z jeho dosavadních výkonů. Oproti tomu vnímaná vlastní zdatnost člověka se zabývá tím, čeho je člověk schopen dosáhnout v budoucnu. Je koncipována tak, aby odhalovala jeho potenciality ve vztahu ke konkrétnímu úkolu v konkrétních podmínkách. Vyjadřuje jedincovo přesvědčení o tom „co mohu udělat"; jde o cílevědomé, kontextově specifické, do budoucnosti orientované úvahy/ soudy ve vztahu k úzce vymezenému úkolu. Druhý rozdíl je v tom, že sebepojetí člověka má prvky jak deskriptivní, tak hodnotící, zatímco u vnímané vlastní zdatnosti převládá hlavně deskriptivní pohled. Třetí rozdíl vyplývá z toho, nakolik vstupuje do hry vztahový rámec. Výzkumů na dané téma je zatím málo, ale badatelé předpokládají, že sebepojetí člověka je patrně ovlivňováno sociálním kontextem, včetně negativního dopadu sociálního srovnávání jedince s druhými lidmi (jsem horší než..). Oproti tomu u vnímané vlastní zdatnosti by se měly jedincovy úvahy vztahovat $\mathrm{k}$ tomu, jak si vede při řešení daného úkolu, nikoli k tomu, jak si vede ve srovnání s jinými lidmi.

Lokalizace rozhodujícího vlivu (locus of control). Tento anglický termín se obvykle překládá do češtiny jako „lokalizace kontroly“. Vhodnější se nám zdá překlad, který navrhl J. Výrost (1989, s. 152): lokalizace rozhodujícího vlivu. Základní myšlenky teorie lokalizace rozhodujícího vlivu jsou dvě: 1 . kam člověk situuje příčiny svých úspěchů či neúspěchů; zda mimo sebe, anebo je připisuje, sám sobě, 2. zda jsou to příčiny, které může sám nějak ovlivnit, anebo jsou z jeho pohledu neovlivnitelné. Důsledky těchto úvah jsou zásadní: pokud za úspěchy či neúspěchy stojí př́činy vnější a neovlivnitelné (náhoda, smůla, omezenost nadřízených, špatné předpisy), pak se sebou nemusí nic dělat. Pokud za úspěchy či neúspěchy stojí přičiny osobní, pak člověk rozlišuje příčiny, které sám neovlivní a příčiny ovlivnitelné (snaživost, vytrvalost, doba věnovaná př́ípravě, intenzita učení).

Lokalizace rozhodujícího vlivu se podle Bandury (2006b) liší od vnímané vlastní zdatnosti tím, že se netýká jedincem vnímaných vlastních schopností/způsobilostí, ale jeho přesvědčení, zda výsledky jeho činnosti jsou determinovány jeho vlastním 
jednáním anebo vnějšími silami, vnějšími okolnostmi, které on sám nemůže nijak ovlivnit. Vysoká úroveň lokalizace rozhodujíć́ho vlivu nemusí nutně znamenat, že se člověk cítí oprávněn něco dělat nebo že je v pohodě. Např. žák, který má zatím výborné známky, se může domnívat, že jich sice dosáhl díky svým dosavadním výkonům, ale cítí se skleslý, malomyslný, protože je přesvědčen, že nemá na to, aby ty to vynikající výkony podával pořád.

Motivace člověka. Samotný pojem motivace je velmi široký a je obtížné ho jednoznačně definovat. 0 jeho vysvětlení usiluje mnoho psychologických teorií. Pravdu má zřejmě Irvine (2018), když mluví o pojmu vyšší úrovně - metapojmu. Zmíněný autor se pokusil o utřídění různých teorií motivace pomocí dvou dimenzí, které odvodil ze dvou zajímavých motivačních teorií. Tou první je teorie očekávaných hodnot (expectancy-valued theory). Vznikla v 50. a 60. letech 20. století a snažila se vysvětit výkonovou motivaci lidí. Jejím tvůrcem je J. W. Atkinson a pedagogické aplikace rozpracovala J. Ecclesová. Tato teorie předpokládá, že volba úkolů, vytrvalost žáka při jejich řešení a úspěšnost řešení závisí na dvou faktorech: na přesvědčení žáků, jaká je $v$ jejich př́ípadě pravděpodobnost úspěchu při řešení úkolu a na subjektivní hodnotě, kterou danému úkolu přikládají. Vztah této teorie k žákem vnímané vlastní zdatnosti je zřejmý: přesvědčení žáka o tom, zda je $v$ jeho schopnostech splnit, vyřešit daný úkol a zda se vůbec rozhodne ho řešit; pokud bude nucen ho řešit, tak s jakým nasazením. Druhá teorie vychází z úvahy, že z principu můžeme rozlišit dva základní typy motivace: vnitřní a vnější podle důvodů, které vedou člověka k určitému jednání, nebo podle cílů, kterých chce jedinec tímto jednáním dosáhnout. Výstižně to formulovali Ryan a Deci (2000, s. 55), dle nichž „základní rozdíl mezi dvěma typy motivací spočívá $v$ tom, že při vnitřní motivaci člověk něco dělá, protože je to zajímavé nebo prŕjemné, zatímco při vněǰsí motivaci člověk něco dělá proto, že to vede k jasně definovanému výsledku."

Vztah motivačních typů k vnímané vlastní zdatnosti člověka znázorňuje obr. 5

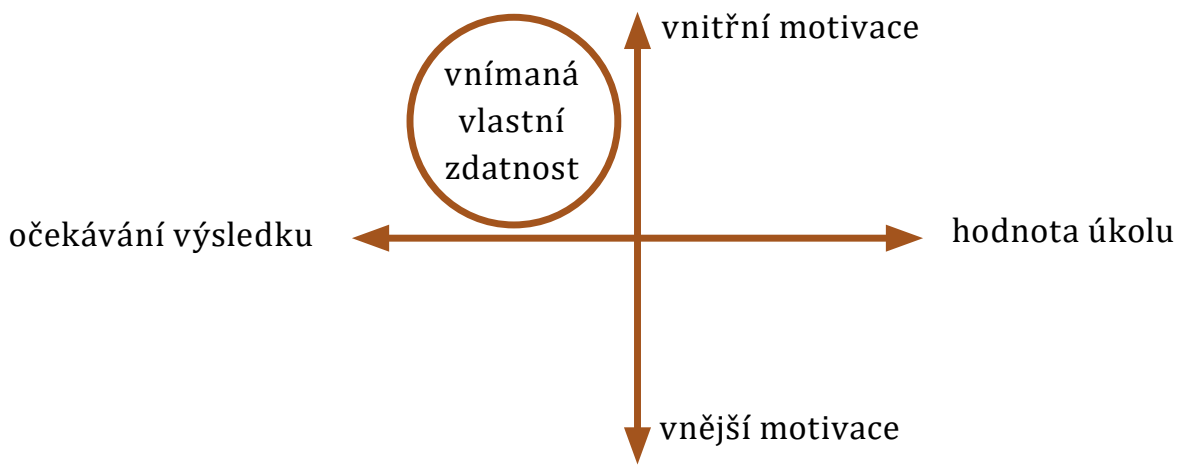

Obr. 5: Vztah motivačních typů k vnímané vlastní zdatnosti člověka (modifikovaně podle Irvine, 2018, s. 22) 
Odolnost (resilience) člověka. Podle Americké psychologické asociace (APA, 2014) se odolností rozumí proces dobré adaptace toho člověka, který čelí tváří v tvář nepřízni osudu, traumatu, tragédii, hrozbám nebo významným zdrojům stresu. Podle Southwicka et al. (2014) je třeba při definování odolnosti člověka zpřesnit, zda se odolnost chápe jako trvalá vlastnost jedince, nebo jako děj, proces anebo jako výsledek tohoto procesu. Odborníci se u laiků setkávají také s binárním chápáním odolnosti (člověk odolnost bud' má nebo nemá), což je chybný přístup. Ve skutečnosti má odolnost podobu kontinua a navíc: neprojevuje se ve všech oblast života ve stejném stupni. V některých oblastech a situacích je člověk odolnější více, v jiných méně (viz např. školní situace versus osobní život). Odolnost se v průběhu času může měnit (zvyšovat, snižovat) v závislosti na ontogenetickém vývoji jedince, na jeho životních zkušenostech a vlivu druhých lidí.

Jak souvisí odolnost člověka s jeho vnímanou vlastní zdatností? Vnímaná vlastní zdatnost podle Bandury (2001) zřejmě ovlivňuje schopnost člověka adaptovat se i na nepříznivou životní situaci, pružně se vypořádat s obtížnými situacemi. Ovlivňuje i jeho aspirace, jeho analytické myšlení a vytrvalost tváří v tvář neúspěchu. Platí to i obráceně, pokud člověk nevěří, že může svým jednáním dosáhnout požadovaných cílů, má jen malou motivaci vzdorovat neúspěchu či těžkým životním situacím. Doložila to i výzkumná sonda u adolescentů ve věku 16-19 let (Hamill, 2003). Výzkum u nich sledoval vnímanou vlastní zdatnost, vnímanou kontrolu a řízení, reakci na stres, jejich vytrvalost, zvládací strategie a řešení speciálně zkonstruovaných učebních úloh.

Analýza výsledků identifikovala čtyři skupiny žáků: 1. odolní, 2. kompetentní, 3. maladaptivní, 4. ti, co nezažili žádnou nepřízeň osudu a současně jsou málo kompetentní. První dvě skupiny se prakticky nelišily ve sledovaných proměnných. Jediný rozdíl spočíval v tom, že odolní žáci vykazovali vyšší frekvenci problémového chování. Obě skupiny byly kompetentní v činnostech, které považovaly za důležité. Maladaptivní žáci vykazovali vysokou četnost problémového a agresivního chování, nesnažili se přizpůsobit požadavkům. Měli nižší úroveň obecně vnímané vlastní zdatnosti a důvěry v sebe sami. Čtvrtá skupina žáků byla překvapením i pro badatele. Žáci se vyznačovali nejvyšší úrovní problémového chování, méně si věřili, nedokázali dobře zvládat zátěžové situace, ale zatím se nesetkali ve svém životě s žádnou vážnou událostí. 



\section{VNÍMANÁ VLASTNÍ ZDATNOST VE ŠKOLNÍM KONTEXTU}

Školní vnímaná vlastní zdatnost (academic self-efficacy). Rozumí se jí jedincovo přesvědčení, že je schopen zorganizovat si učební aktivity a uskutečňovat je tak, aby dosáhl požadované úrovně školního výkonu (Zimmerman, 1995). Jedincem vnímanou vlastní zdatnost lze také charakterizovat jako jeho přesvědčení, které pozitivně působí na jeho školní výkony, na jeho učební úsilí a vede ke školním úspěchům (Multon, Brown, \& Lent, 1991).

Není možné ve vymezeném prostoru prezentovat výzkumy vnímané vlastní školní zdatnosti žáků a učitelů za posledních deset let, jsou jich tisíce. Pro ilustraci různých směrů výzkumného snažení uvedeme jenom vybrané příklady.

Žáci a vnímaná vlastní zdatnost. Zájem badatelů o vnímanou vlastní zdatnost žáků má stoupající tendenci a tematický záběr výzkumů se rozšiřuje. Hodně se píše o školní zdatnosti vnímané samotnými žáky, ale ta se nemusí projevovat pouze ve škole a přímo ve výuce. Užitečný výzkum realizoval tým německých badatelů, který si položil otázku, nakolik se čtyři zdroje vnímané vlastní zdatnosti (postulované Bandurovou teorií) mění u žáků 7. třídy, když se zkoumají ve třech odlišných sociálních kontextech: v rámci rodiny žáka, v rámci vrstevníků daného žáka a v rámci školy (Gebauer, McElvany, \& Bos et al., 2020). Výsledky zmíněného výzkumu empiricky potvrdily existenci čtyř základních zdrojů vnímané vlastní zdatnosti žáků, tj. vlastní zkušenosti jedince s úspěšným zvládnutím úkolu, zástupného učení, verbálního přesvědčování, fyziologické a emoční aktivace. Současně se ukázalo, že jednotlivé zdroje se podílejí na vnímané zdatnosti žáků v rozdílných sociálních kontextech odlišným způsobem.

V rámci rodiny se uplatňuje pouze jeden zdroj školní zdatnosti - verbální a sociální - přesvědčování žáka rodiči. Toto přesvědčování je účinné pouze u žáků, kteří žijí v dobře situovaných rodinách, rodiče mají vyšší vzdělání a rodina má 
kulturní kapitál. V sociálně slabších rodinách je přesvědčování žáka ze strany rodičů neúčinné. Pokud jde o vrstevníky (at’ už se jedná o spolužáky nebo kamarády mimo školu) patřri u dospívajících žáků mezi osoby, na jejichž mínění žák dá. Školní vnímanou vlastní zdatnost žáka však pozitivně ovlivní pouze ti vrstevníci, kteří jsou na tom prospěchově dobře, mají podobné zájmy, jsou obdobně studijně zdatní nebo jsou na tom trochu lépe a fungují jako vzor. U vrstevníků převládá verbální a sociální přesvědčování spolu s fyziologickou aktivací. Třetím sociální kontextem byla škola. Zde se uplatnily tyto zdroje: vlastní zkušenosti jedince s úspěšným zvládnutím úkolu, verbální přesvědčování, fyziologická aktivace žáků.

Další výzkum (tentokrát v Řecku) se zajímal o zvládání zátěžových situací spojených se vzájemným šikanováním žáků ve věku 10-12 let. Ukázal, že vnímaná vlastní zdatnost žáka je moderátorem mezi snahou spolužáků ho šikanovat a úspěšností žáka tuto zátěžovou situaci zvládnout (Kokkinos, Panagopoulou, Tsolakidou et al., 2015). Žáci s nízkou a střední úrovní sociálně a emočně vnímané zdatnosti (tedy žáci, kteří si nevěřili, že stresovou situaci zvládnou) používali nevhodné a neúčinné zvládací strategie typu pasivní vyhýbání se, rezignování. Výsledkem bylo, že se $s$ větší pravděpodobností stali terčem šikanování. Naopak žáci s vysokou úrovní sociálně a emočně vnímané zdatnosti (tedy žáci, kteří si věřili, že stresovou situaci zvládnou), již používali účinné zvládací strategie typu pozitivní sebeinstruování, co je třeba udělat, využívání sociální opory od spolužáků, se obvykle nestali obětí šikanování.

Učitelé i další pracovníci školy a vnímaná vlastní zdatnost. Vnímaná pedagogická zdatnost učitelů se zřejmě zakládá už v době jejich pregraduálního studia, tj. v době, kdy se na svou profesi teprve připravují. Naznačuje to výzkum australského autora Christiana (2017). Ten se soustředil na situaci v polovině bakalářské části učitelské přípravy, kdy se budoucí učitelé pokoušejí o své první odborné seznamování s reálnou výukou. Citovaný autor postavil svůj výzkum na důležitosti vztahu mezi vnímanou pedagogickou zdatností budoucího učitele a observačním učením (Bandura, 1997). Podle Bandury probíhá observační učení ve čtyřech fázích. Tou první je pozornost, kterou pozorovatel-student učitelství věnuje modelu, vzoru, od něhož se má potřebné dovednosti naučit. Pozornost studenta bývá ovlivněna mírou vnímané podobnosti mezi učitele-vzorem a studentem samotným, dále studentovým vnímáním pedagogických dovedností učitele-vzoru a sociálním statusem vzoru. Tou druhou fází je zapamatování, které vyžaduje podržet v paměti příslušnou dovednost a ověřit si celou její sekvenci bud' zopakováním si postupu jen „V duchu“ nebo pokusem prakticky si ji vyzkoušet. Třetí fáze má podobu přesného zopakování osvojovaného pedagogického postupu ve vhodných podmínkách. Čtvrtou a závěrečnou fází je motivovanost studenta. Ta předpokládá, že existuje vnější nebo vnitřní důvod k napodobování vzoru. 
Kvalitativní výzkumná studie vycházela z diskuse studentů-budoucích učitelů ve čtyřech ohniskových skupinách; v každé bylo průměrně 13 osob. Diskuse byla nahrávána, přepsána do protokolu a podrobena tematické analýze. Celkem bylo identifikováno 18 výukových strategií; ty byly seskupeny do čtyř tematických okruhů:

1. modelování, napodobování vzoru (učitel předvádí vzor postupu; mikrovyučování, při němž spolužáci-budoucí učitelé hrají roli žáků; fakultní (cvičná) škola zajistila živé předvedení vzorových vyučovacích hodin, jež byly technicky přenášeny do jiné budovy; předvedení vybraných pedagogických situací z videozáznamu;

2. příručka pro studenty prezentující tvorbu „lešení“ (scaffolding) pro účinný pedagogický postup; písemná příprava na vyučovací hodinu; seznam možných otázek, které rozvádějí určitou pedagogickou taktiku; prezentování učiva; seznam zdrojů, z nichž bylo čerpáno; přizpůsobení taktiky věku žáků/specifickému učivu; výklad; odlišné pedagogické strategie; důraz na slovní gramotnost nebo na matematickou gramotnost; obsahová stránka výuky; profesionální komunikace ve škole;

3. komunikace; otevřený dialog (vysvětlení); výklad a systematická zpětná vazba;

4. kultura učení: prostředí poskytující sociální oporu; vrstevnické prostředí.

Tento výzkum potvrdil užitečnost systematicky prováděného observačního učení a postupné budování „lešení“ pro pedagogické postupy u budoucích učitelů v počátcích jejich pedagogické praxe na školách. Současně s prvními pedagogickými výstupy se u budoucích učitelů vynořuje a zpřesňuje jejich vnímaná pedagogická zdatnost.

Některé definice chápou vnímanou vlastní zdatnost učitelů jako přesvědčení učitelů o tom, že jsou schopni/způsobilí být kvalitními, efektivními učiteli (Morris, Usher, \& Chen, 2017). Najdeme i stanovisko, že vnímaná vlastní zdatnost učitelů determinuje postoje učitelů k výukové praxi i jejich přístup k využívání bohatého spektra výukových postupů (Tschannen-Moran, Woolfolk Hoy, \& Hoy, 1998).

Výzkumný tým korejských badatelů (Choi, Lee, \& Kim, 2019) si řekl, že dosavadní výzkumy studovaly hlavně případy, kdy vysoká úroveň vnímané vlastní pedagogické zdatnosti dodávala učitelům sebedůvěru, aby vyzkoušeli ve výuce nové pedagogické přístupy. Korejský tým zkusil postup obrátit a položil si otázku: Když si učitelé sami vyzkoušejí nový pedagogický přístup (např. projektovou výuku) a budou úspěšní, zvýší se jejich odborná jistota a vnímaná pedagogická zdatnost? Za nový pedagogický postup zvolili badatelé projektovou výuku. Ukázalo se, že netradiční výukový př́ístup většinu učitelů zaujal. Museli se se sice pečlivěji připravovat na vyučovací hodiny, museli důkladněji promýšlet, jak vzbudit zájem svých žáků, ale jejich hodiny byly daleko živější. Žáci uvedli, že je výuka více baví, 
že mohou přicházet s vlastními nápady, že více diskutují s učitelem i se spolužáky. Výzkumná data prokázala pozitivní vztah mezi uskutečňovanou projektovou výukou a zvýšením úrovně vnímané vlastní pedagogické zdatnosti učitelů. Otevírá se tím nová cesta ke zvyšování pedagogické zdatnosti učitelů, při níž získání pozitivních zkušeností s novými pedagogickými postupy funguje jako účinný zprostředkující faktor.

Problematika inkluze dětí s různými typy postižení do běžných škol je nadnárodní záležitostí a řeší ji všechny vyspělé země. Specifickým př́ípadem je začleňování dětí s poruchami autistického spektra, nebot' práce s těmito dětmi je pro učitele zdrojem stresu. Řešení situací, které se denně objevují, vyžaduje od učitelů značné zvládací úsilí. Francouzský výzkum (Boujut, Popa-Roch, Palomares et al., 2017) vyšel z předpokladu, že přímé účinky nízké pedagogické zdatnosti na vznik syndromu vyhoření u učitelů jsou známy a jsou empiricky doloženy. Téměř nic se však neví o neprrímých účincích, které jsou zprostředkovány stresem a nevhodnými zvládacími strategiemi těch učitelů, již mají ve třídě dětské autisty. Autoři výzkumu vyšli z transakčního modelu stresu Lararuse a Folkmanové, který umožňuje vysvětlit př́mý vztah mezi vnímanou vlastní zdatností učitele a jeho vyhořením, ale také nepřímý vztah zprostředkovaný mediačními procesy typu: vnímaný stres, vnímaná kontrola a řízení žáků i použité strategie zvládání zátěže.

Výsledky francouzského výzkumu ukázaly, že nízká úroveň vnímané pedagogické zdatnosti u učitelů, kteří mají ve tř́ídě dítě s poruchou autistického spektra, obvykle používají zvládání zaměřené na emoce, i když se ví, že je maladaptivní. Zvládání zaměřené na emoce totiž vede $\mathrm{k}$ vyššímu emočnímu vyčerpání, depersonalizaci a nižší pravděpodobnosti úspěchu. Učitelé, kteří si sami nevěří, že by dokázali pracovat s autisty, zřejmě častěji využívají strategií, jimiž se vyhýbají řešení pedagogických problémů. Tito učitelé se zabývají spíše sami sebou (snaží se tlumit svůj emoční distres ze situací, na něž se nedokáží adaptovat). Přitom je známo, že pro práci s dětskými autisty jsou mnohem účinnější zvládací strategie zaměřené na řešení problémů. Ty se u zkoumaných učitelů téměř neobjevovaly (Boujut, Popa-Roch, \& Palomares et al., 2017). Lze to vysvětlit mj. tím, že ne všichni učitelé jsou vyškoleni pro práci s dětskými autisty, a proto se cítí neschopní, bezmocní tváří v tvář novým problémům. Jsou frustrováni, zklamáni, uvědomují si, že selhávají ve svých pedagogických dovednostech (Busby, Ingram, Bowron et al. 2012). Není tedy divu, že se u nich začne projevovat syndrom vyhoření.

Na závěr našeho výběrového přehledu aplikací Bandurovy teorie jsme si nechali školní poradenství (Erlich, \& Russ-Eft, 2011). Jde o důležitou složku institucionální pomoci žákům, kteří mají problémy s vlastním učením či chováním anebo problémy se spolužáky, některými učiteli či problémy v rodině. Cílem školních poradenských služeb je mj. zvýšit úroveň žákem vnímané vlastní zdatnosti, jeho úroveň 
autoregulace učení a chování, jeho strategie zvládání obtíží, jeho plánování vlastní budoucnosti.

Setkání poradenského pracovníka se žákem obvykle začíná zjištěním problémů, s nimiž žák přichází, a jeho představy, co by chtěl změnit, čeho by chtěl výhledově dosáhnout (Bandurův pojem forethought). Výsledkem je stanovení společných cílů, kterých by chtěli žák a poradenský pracovník dosáhnout, a rámcový plán postupu, jak k těmto cílům dojít. Druhou etapou jsou školně-poradenské intervence. Žák se učí zvládací strategie pomocí pozorování žákovských vzorů, získáváním osobních zkušeností s nacvičováním vhodných postupů (learning by doing). Poradce mu poskytuje zpětnou vazbu a povzbuzuje ho; snaží se, aby se žák nevyhýbal náročným situacím, naučil se redukovat občasné stavy úzkosti, obavy ze selhání. Třetí etapa je výkonová. Žák se učí pracovat samostatněji. Poradce ustupuje do pozadí a žák zkouší řídit sám sebe, dospět až k autoregulaci. Čtvrtou, závěrečnou etapou je žákova sebereflexe vlastního uvažování a jednání. Žák dokáže analyzovat své myšlení a jednání, zdůvodňovat si svá rozhodnutí, vyhledávat chyby ve svých aktivitách a opravovat je. Učí se samostatnosti a odpovědnosti za přijatá rozhodnutí. Učí se zlepšovat sám sebe.

\section{1}

\section{Diagnostikování vnímané vlastní zdatnosti}

Vnímaná vlastní zdatnost učitelů i žáků byla během poledních 25 let zjišt’ována převážně pomocí kvantitativních nástrojů, tj. pomocí dotazníků, které používaly numerické posuzovací škály likertovského typu. Přehledová studie (Glackin, Hohenstein, 2018) shrnula některé slabiny dosavadních dotazníkových šetření takto:

- dotazníkové položky nedokáží dobře zachytit bohatost a individuální různorodost konstruktu „vnímaná vlastní zdatnost“ v určité oblasti lidské činnosti,

- pro autory dotazníku bývá problém nalézt optimální poměr mezi obecností a specifičností položek (při velké specifičnosti se obtížně zobecňuje, při velké obecnosti zase obtížně predikuje),

- pokud je zjišt'ování vnímané vlastní zdatnosti jedince založeno pouze na sebehodnocení, objevují se dvě zkreslení získaných výsledků: a) mnoho respondentů nevyužívá krajních hodnot Likertovy škály (naprosto souhlasím-naprosto nesouhlasím), takže u pětistupňové škály pracují vlastně s třístupňovou; b) u řady respondentů ovlivňuje posuzování sebe sama efekt sociální žádoucnosti odpovědí, tj. tendence prezentovat se v co nejlepším světle, zkreslovat realitu,

- vnímaná vlastní zdatnost je spojitá proměnná, ale při interpretaci získaných výsledků bývá často redukována do dichotomické podoby: skupina s osob 
s vysokými hodnotami je chápána pozitivně, zatímco skupina s nízkými hodnotami negativně; to likviduje bohatost reality, znemožňuje detailnější typologii jedinců a poučené intervence,

- ukazuje se, že metodologické přístupy bude třeba doplnit o širší využívání kvalitativního př́stupu; zatím šlo spíše o sporadické aktivity, které pracovaly s pozorováním učitelů a žáků při výuce, s hloubkovými rozhovory, s učitelskými popisy faktorů, jež ovlivňují jejich pohled na vlastní pedagogickou zdatnost.

Po vstupním zamyšlení nyní přejdeme ke konkrétním příkladům. Jak jsme výše uvedli, tradiční, obecně použitelné dotazníky se používají v pedagogických aplikacích už léta. $V$ uplynulém desetiletí se pozornost badatelů obrátila také k oborově a tematicky specifickým nástrojům (domain specific self-efficacy), které dovolují zjišstovat určité typy vnímané vlastní zdatnosti osob. Podrobnosti přináší tab. 1, v níž jsou různorodé dotazníky seřazeny podle doby svého vzniku.

\section{Tab. 2.1: Dotazníky zjišt'ující specifické typy vnímané vlastní zdatnosti u lidí}

\begin{tabular}{|c|c|c|c|c|c|}
\hline Název a autor & $\begin{array}{l}\text { Počet } \\
\text { polo- } \\
\text { žek }\end{array}$ & $\begin{array}{l}\text { Způsob } \\
\text { odpoví- } \\
\text { dání }\end{array}$ & Obsahová struktura & $\begin{array}{l}\text { Relia- } \\
\text { bilita }\end{array}$ & Komentář \\
\hline $\begin{array}{l}\text { Self-efficacy ques- } \\
\text { tionnaire of clinical } \\
\text { communication } \\
\text { skills (Axboe et al, } \\
2010 \text { ) }\end{array}$ & 12 & $\begin{array}{l}\text { desetis- } \\
\text { tupňová } \\
\text { škála }\end{array}$ & $\begin{array}{l}\text { Jednodimenzionální } \\
\text { struktura }\end{array}$ & $\begin{array}{l}\text { Cron- } \\
\text { bach. } \\
\text { alfa: } \\
0,95\end{array}$ & $\begin{array}{l}\text { Dotazník je sice ur- } \\
\text { čen pro zdravotníky, } \\
\text { ale dal by se snadno } \\
\text { modifikovat i pro } \\
\text { učitele. }\end{array}$ \\
\hline $\begin{array}{l}\text { Teacher Self-Effi- } \\
\text { cacy for Inclusive } \\
\text { Practices (Sharma } \\
\text { et al. 2012) }\end{array}$ & 18 & $\begin{array}{l}\text { šestis- } \\
\text { tupňová } \\
\text { škála }\end{array}$ & $\begin{array}{l}\text { Tři faktory vnímané } \\
\text { vlastní zdatnosti při } \\
\text { zvládání inkluzivní } \\
\text { výuky: } \\
\text { 1. Zdatnost při realizaci } \\
\text { inkluzivní výuky } \\
\text { 2. Zdatnost při spoluprá- } \\
\text { ci s rodiči a odborníky } \\
\text { 3. Zdatnost při řízení } \\
\text { třídy a chování žáků }\end{array}$ & $\begin{array}{l}\text { Cron- } \\
\text { bach. } \\
\text { alfa: } \\
0,93 \\
0,85 \\
0,85\end{array}$ & $\begin{array}{l}\text { Dotazník byl ověřen } \\
\text { u } 609 \text { budoucích } \\
\text { učitelů ve čtyřech } \\
\text { zemích: Kanada, } \\
\text { Austrálie, Hong } \\
\text { Kong, Indie. }\end{array}$ \\
\hline
\end{tabular}




\begin{tabular}{|c|c|c|c|c|c|}
\hline Název a autor & $\begin{array}{l}\text { Počet } \\
\text { polo- } \\
\text { žek }\end{array}$ & $\begin{array}{l}\text { Způsob } \\
\text { odpoví- } \\
\text { dání }\end{array}$ & Obsahová struktura & $\begin{array}{l}\text { Relia- } \\
\text { bilita }\end{array}$ & Komentář \\
\hline $\begin{array}{l}\text { Crisis Self-Efficacy } \\
\text { Scale (Park, 2016) }\end{array}$ & 12 & $\begin{array}{l}\text { sedmis- } \\
\text { tupňová } \\
\text { škála }\end{array}$ & $\begin{array}{l}\text { Čtyři faktory vnímané } \\
\text { vlastní zdatnost při zvlá- } \\
\text { dání krizové události: } \\
\text { 1. Akční zdatnost } \\
\text { 2. Preventivní zdatnost } \\
\text { 3. Výkonová zdatnost } \\
\text { 4. Zdatnost při zvládání } \\
\text { nejistoty }\end{array}$ & $\begin{array}{l}\text { Cron- } \\
\text { bach. } \\
\text { alfa: } \\
0,91 \\
0,83 \\
0,96 \\
0,93\end{array}$ & $\begin{array}{l}\text { Zkoumaný soubor } \\
\text { tvořilo } 302 \text { osob } \\
\text { běžné populace } \\
\text { (průměrný věk } \\
\text { 35,25 let; variační } \\
\text { rozpětí 19-68 let). } \\
\text { Dál byl administro- } \\
\text { ván nově zkonstru- } \\
\text { ovaný dotazník } \\
\text { obecné vnímané } \\
\text { vlastní zdatnosti } \\
\text { (8 položek) a do- } \\
\text { tazník sociální žá- } \\
\text { doucnosti odpovědi } \\
\text { (10 položek). }\end{array}$ \\
\hline $\begin{array}{l}\text { Self-efficacy for } \\
\text { reading (Schüller } \\
\text { et al. 2016) }\end{array}$ & 3 & $\begin{array}{l}\text { čtyř- } \\
\text { stupňová } \\
\text { škála }\end{array}$ & $\begin{array}{l}\text { Byly použity tyto pro- } \\
\text { měnné: } \\
\text { 1. Tematicky kongruent- } \\
\text { ní výsledky } \\
\text { 2. Tematicky nekon- } \\
\text { gruentní důsledky } \\
\text { 3. Subjektivní normy } \\
\text { 4. Vnímaná vlastní } \\
\text { čtenářská zdatnost } \\
\text { 5. Subj. hodnocené okol- } \\
\text { nosti, za kterých dítě čte }\end{array}$ & $\begin{array}{l}\text { Cron- } \\
\text { bach. } \\
\text { alfa: } \\
0,82 \\
0,82 \\
0,70 \\
\mathbf{0 , 7 5} \\
0,79\end{array}$ & $\begin{array}{l}\text { Výzkum se usku- } \\
\text { tečnil u } 980 \text { žáků } \\
\text { primárních škol } \\
\text { (průměrný věk } \\
8,67 \text { let). } \\
\text { Zjišt'oval motivova- } \\
\text { nost žáků ke čtení } \\
\text { ve volném čase. }\end{array}$ \\
\hline $\begin{array}{l}\text { Astronomy } \\
\text { Teaching Self-Effi- } \\
\text { cacy Belief Scale } \\
\text { (Demirci, Ozyurek, } \\
2018 \text { ) }\end{array}$ & 13 & $\begin{array}{l}\text { pětis- } \\
\text { tupňová } \\
\text { škála }\end{array}$ & $\begin{array}{l}\text { Tři faktory vnímané } \\
\text { vlastní zdatnosti při } \\
\text { výuce astronomie: } \\
\text { 1. Výsledky studentů po } \\
\text { výuce astronomie } \\
\text { 2. Učitelovy strategie } \\
\text { výuky astronomie } \\
\text { 3. Obtížnost výuky ast- } \\
\text { ronomie pro učitele }\end{array}$ & $\begin{array}{l}\text { Cron- } \\
\text { bach. } \\
\text { alfa: } \\
0,90 \\
0,83\end{array}$ & $\begin{array}{l}\text { Dotazník byl ověřen } \\
\text { u } 106 \text { učitelů pří- } \\
\text { rodovědných před- } \\
\text { mětů na základních } \\
\text { a středních školách. }\end{array}$ \\
\hline
\end{tabular}




\begin{tabular}{|c|c|c|c|c|c|}
\hline Název a autor & $\begin{array}{l}\text { Počet } \\
\text { polo- } \\
\text { žek }\end{array}$ & $\begin{array}{c}\text { Způsob } \\
\text { odpoví- } \\
\text { dání }\end{array}$ & Obsahová struktura & $\begin{array}{l}\text { Relia- } \\
\text { bilita }\end{array}$ & Komentár̆ \\
\hline $\begin{array}{l}\text { Teachers' bullying } \\
\text { intervention self- } \\
\text { efficacy (Fischer, } \\
\text { Bilz, 2018) }\end{array}$ & 5 & $\begin{array}{l}\text { čtyř- } \\
\text { stupňová } \\
\text { škála }\end{array}$ & $\begin{array}{l}\text { Jednodimenzionální } \\
\text { struktura; samostatná } \\
\text { položka zjišt'ovala formu } \\
\text { šikanování (verbální, } \\
\text { fyzickou, sociální, kyber- } \\
\text { šikanu) }\end{array}$ & $\begin{array}{l}\text { Rayko- } \\
\text { vovo } \\
\rho=0,82\end{array}$ & $\begin{array}{l}\text { Výzkum se usku- } \\
\text { tečnil u } 495 \text { učitelů } \\
\text { základních a střed- } \\
\text { ních škol. }\end{array}$ \\
\hline $\begin{array}{l}\text { Computational } \\
\text { Thinking Self-effi- } \\
\text { cacy Scale (Kukul, } \\
\text { Karataş, 2019) }\end{array}$ & 18 & $\begin{array}{l}\text { pětis- } \\
\text { tupňová } \\
\text { škála }\end{array}$ & $\begin{array}{l}\text { Čtyři faktory vnímané } \\
\text { vlastní zdatnosti: } \\
\text { 1. rozmýšlení } \\
\text { 2. abstrahování } \\
\text { 3. rozkládání } \\
\text { 4. generalizování }\end{array}$ & $\begin{array}{l}\text { Cron- } \\
\text { bach. } \\
\text { alfa: } \\
0,772 \\
0,774 \\
0,701 \\
0,718\end{array}$ & $\begin{array}{l}\text { Dotazník zjišt'uje, } \\
\text { jak si žáci věří při } \\
\text { řešení úloh pomocí } \\
\text { výpočetní techniky. } \\
\text { Byl ověřen } \\
\text { u } 319 \text { žáků 5.-7. tří- } \\
\text { dy. }\end{array}$ \\
\hline
\end{tabular}

Přechod mezi kvantitativním a kvalitativním přístupem tvoří kognitivní interview, přesněji řečeno jedna z jeho podob - respondentovo přemýšlení nad svou odpovědí nahlas (TAP-Think Aloud Protocol). Postup je užitečný, ale objevily se obavy, zda samo hlasité přemýšlení není příčinou určitého zkreslení oproti přemýšlení „V duchu“. Zdá se však, že tento vliv není výrazný. Druhý metodologický problém spočívá v tom, že se jedná o tzv. souběžnou verbalizaci. Respondent jednak čte znění položky a píše svoji odpověd', jednak nahlas sděluje, jak o své odpovědi uvažuje, co všechno bere v úvahu. Metaanalýza (Fox, Ericsson, \& Best, 2011) však ukázala, že v případě, kdy se dodržují odborné instrukce, není vliv souběžné verbalizace statisticky významný.

Výzkum (Pepper, Hodgen, \& Lamesoo et al., 2018) studoval žákovské hlasité přemýšlení nad položkami dotazníku, který u žáků zjištooval hodnocení své vlastní matematické zdatnosti (8 položek) v rámci projektu PISA. Autoři zjistili, že existují určité rozdíly mezi patnáctiletými žáky ze čtyř zemí: Anglie, Estonska Hongkongu a Nizozemska. Ukázaly se také chyby v překladu některých výrazů do národních jazyků (viz např. pojem graf v estonské verzi), čtení nahlas indikovalo slova, jejichž obsahu žáci př́liš nerozuměli; žáci se také lišili v rozsahu svých verbalizovaných úvah o možné odpovědi na danou položku. 
V posledních deseti letech přibývají snahy o korektní využívání ryze kvalitativního př́stupu, což je potěšitelné. Podívejme se na některé možnosti.

Rozhovor. Výzkum u čtyř začínajících učitelů na prvním stupni základní školy studoval jejich vnímanou pedagogickou zdatnost v hodinách čtení (Hastings, 2012). Byl použit polostrukturovaný rozhovor, jehož průběh byl nahráván a poté analyzován.

Byly sledovány tyto tematické okruhy:

1. Ideální vyučovací hodina čtení, učitelem běžně používané postupy; učitelovy modely, vzory; učitelova vize do budoucna.

2. Ve kterých specifických oblastech pedagogické práce se daný učitel cítí být odborně velmi zdatným?

3. Které typy profesního rozvoje mu pomohly zvýšit jeho vnímanou vlastní zdatnost právě pro výuku čtení?

Výsledky ukazují, že u zkoumaných začínajících učitelů hrají důležitou roli při zvyšování vnímané vlastní zdatnosti dva ze čtyř zdrojů: zástupná zkušenost spolu s verbálním a sociálním přesvědčováním. Nikoli zážitek úspěšného zvládnutí úkolu či fyziologické a emoční stavy.

Psaní. Celkem 24 budoucích učitelů hudební výchovy (pod vedením dvou vysokoškolských profesorů) se zúčastnilo letního hudebního tábora pro malé děti ve věku 3,5 až 8 let. Děti byly rozděleny do dvou věkových skupin (jedné předškolní a druhé školní) a vždy dopoledne absolvovaly hudební aktivity pod vedením budoucích učitelů. Tábor trval 6 týdnů. Budoucí učitelé měli - kromě odborné práce s dětmi - za úkol vést si podrobný elektronický deník o svých zkušenostech s hudební výchovou malých dětí a proměnách své odborné zdatnosti. Průměrný počet stran za celé šestitýdenní období u jednoho studenta činil 140 stran textu. Reflektivní texty text byly analyzovány s využitím tzv. zakotvené teorie. Autoři výzkumu identifikovali $v$ textech pět témat: výborné zkušenosti s doporučenou učebnicí hudební výchovy pro malé děti; proměny vnímané vlastní hudebně-pedagogické zdatnosti u budoucích učitelů; užití hudby k překlenování kulturních hranic mezi dětmi navzájem i mezi vyučujícími a dětmi; poznávání vývojově vhodných témat pro hudební výchovu malých dětí; propojování témat v rámci hudební výchovy malých dětí a důležité postavení hudební výchovy v kurikulu předškolní a školní výuky obecně (Barry, \& Durham, 2017).

Kreslení. Budoucí učitelé prrírodovědných předmětů na základní škole absolvovali 16týdenní kurz oborové didaktiky. Kladl důraz jak na teoretické, tak praktické znalosti, které učitel potřebuje, aby dokázal naplánovat i realizovat výuku př́rodovědných a zdravotnických témat a zhodnotit její výsledky. K hodnocení přínosu kurzu u 80 studentů byla použita netradiční metoda: před začátkem kurzu a po 
jeho skončení dostali studenti učitelství za úkol nakreslit obrázek sebe sama jako učitele přírodovědného předmětu, jak vyučuje (metoda A Draw a Science Teacher Test Checklist). Součástí metody je také druhá složka - psaný verbální komentář studenta k nakreslenému obrázku. Hodnotitel se z textu dozví, co aktér dělá, proč to dělá, jak se mu to daří atd. Ze studentských kreseb a doprovodných komentářu vykrystalizovala tři témata: učitel jako facilitátor žákova učení; student zkoušející si novou roli učitele; učení žáků prostřednictvím objevování (Del Greco, Bernadowski, \& Parker, 2018).

Analýza kritických událostí. Pro hlubší poznání způsobů, jimiž uvažují adolescenti o své vlastní sociální zdatnosti v interakci se svými vrstevníky, byl použita technika analýzy kritických událostí. Vytvořil ji v 50. letech 20. století J. C. Flanagan. Kritickou událostí se obecně rozumí taková významná událost, při níž je výsledek celé situace ovlivněn chováním dané osoby-aktéra.

Výzkum u 155 adolescentů ve věku 15-17, žáků komprehensivní střední školy, se soustředil na dvě situace, popsané z pohledu aktéra samotného (Nyman, Parisod, \& Axelin et al., 2019). V anonymním dotazníku s otevřenými otázkami měli žáci popsat dvě události: $v$ jedné se mohli v interakci s vrstevníky zachovat podle vlastního rozhodnutí, zatím co ve druhé nemohli. Součástí dotazníku byly tři podotázky. První vyžadovala, aby detailně popsal celou situaci, kdy se neshodl se svými vrstevníky a bud' se zachoval podle svého, anebo se nakonec nezachoval tak, jak by sám chtěl. Druhá podotázka se ptala, proč se mohl nebo nemohl sám rozhodnout a třetí mapovala pocity, které žák prožíval, i úvahy, které mu plynuly hlavou. Texty žákovských odpovědí byla analyzovány pomocí induktivní tematické analýzy. Kritické události v popisu adolescentů vyvstávají jako dynamický proces, $\mathrm{v}$ jehož průběhu adolescent debatuje sám se sebou a uvažuje nad svou sociální zdatností ve styku s vrstevníky, nad možností uhájit svůj názor. Analýza textů identifikovala pět hlavních témat: zamýšlení se adolescenta nad vlastní identitou, sociální atmosféra, která v dané situaci převládala (včetně sociálního tlaku), kognitivní aspekty jedincova rozhodování, afektivní aspekty rozhodování a úvahy o možných důsledcích zamýšleného jednání.

Konečně existuje i třetí možnost - smíšený přístup, který propojuje oba předchozí. Kombinace dotazníku a rozhovoru. Př́kladem může být disertační práce (Abbott, 2010) věnovaná tvorbě dotazníku Creative Self-Efficacy Inventory. Označení dotazníku není př́liš běžné a zaslouží vysvětlení. Vnímaná vlastní zdatnost v oblasti tvořivosti je takový motivační stav, kdy se jedinec projevuje tvořivým způsobem, tedy netradičně. $V$ předchozích letech se o tomto stavu mluvilo jako o zdatnosti člověka generovat nápady, ideje (viz např. Gist, 1989). V referované práci autor předpokládá, že vnímaná vlastní zdatnost člověka v oblasti tvořivosti má dvě 
dimenze: tvořivé myšlení (Creative Thinking Self-Efficacy, CTSE) a tvořivou aktivitu, tvořivý výkon (Creative Performance Self-Efficacy, CPSE).

Projekt výzkumu postuloval dominanci kvalitativního přístupu nad kvalitativním, tj. podobu QUAN-qual. Byl použit sekvenční přístup: autor nejprve uskutečnil kvantitativní fázi výzkumu. Zahrnovala mj. získání 308 respondentů a od nich odpovědi na dotazníkové položky, přípravu dat pro analýzu, vlastní analýzu dat, diskusi získaných výsledků. Teprve poté uskutečnil kvalitativní fázi výzkumu. Ta obsahovala získání 8 informantů, polostrukturované rozhovory, přepis rozhovorů do protokolu, kódování přepsaného textu (deskriptivní, tematické, analytické), diskusi kvalitativních výsledků.

Výsledkem je dotazník, který má celkem 21 položek. Prvních 12 položek se vztahuje k tvořivému myšlení (čtyři faktory: fluence, flexibilita, elaborace, originalita), dalších 9 položek se týká tvořivého výkonu (tři faktory: oblasti aktivit, pole zapojení druhých lidí, osobnost). Kvalitativní sonda identifikovala 7 témat: černé myšlenky, normálnost, rozvíjení tvořivosti praxí, tvořivost jako hra, omezení/ neúspěchy, uznání, vnitřní blok tvořivosti. ${ }^{3}$

Případová studie. Podle Bandury (1997) je důležité si uvědomit, že vnímaná zdatnost kolektivu školy ovlivňuje výsledky žáků. Normy chování žáků ve škole souvisejí s tím, nakolik jsou učitelé dané školy přesvědčeni, že učitelský sbor je schopen vyříkat si problémy s žákovským prospěchem i chováním a řešit je.

Výzkumná případová studie zkoumala, nakolik vybraný aktivní ředitel školy může změnit fungování školy, do níž chodí převážně žáci z chudších vrstev (nejméně 45 \% žáků) a současně jde o školu, v níž se učitelský sbor vyznačuje vysokou úrovní vnímané zdatnosti učitelského kolektivu (Versland, \& Erickson, 2017). Jednalo se o jednopřípadový projekt (jedna vybraná škola) s vnořeným (embedded) přístupem, jehož rámci se sledovalo několik jednotek analýzy.

Ředitel školy vyplnil dotazník vnímané vlastní zdatnosti pro ředitele škol. Učitelé absolvovali individuální polostrukturované rozhovory (mj. o vizi školy, programu proměny školy a jeho reálném implementování, o sdíleném rozhodování ve škole, o vztazích uvnitř učitelského sboru, o klimatu školy. Vyplnili také dotazník o vnímané zdatnosti kolektivu školy. Kromě individuálních rozhovorů se uskutečnily diskuze v ohniskových skupinách učitelů. Data získaná z těchto zdrojů byla doplněna analýzou dokumentace o fungování dané školy.

3 Vztah témat, která identifikovala kvalitativní část výzkumu k novému dotazníku, byl následující: černé myšlenky a normalita se vztahovaly k nízké úrovni CTSE a CPSE; rozvíjení tvořivosti praxí a uznání se vztahovaly k vysoké úrovni CTSE a CPSE; tvořivost jako hra se vztahovala k vysoké i nízké úrovni CTSE; omezení/neúspěchy k vysoké i nízké úrovni CPSE; vnitřní blok tvořivosti byl identifikován jako samostatný problém, nebot' ho zmínili všichni informanti. 
Triangulace získaných dat ukázala, že zlepšené fungování školy ovlivnily dva okruhy aktivit. První okruh zahrnoval zkušenosti a iniciativy učitelů, které přispěly k rozvoji vnímané zdatnosti kolektivu školy. Daná škola se stala vůdčí institucí v zavádění výuky pomocí nových didaktických technologií. Rozvíjela se také výuková spolupráce mezi učiteli navzájem. Druhý okruh se týkal ředitele a jeho zdatnosti ve způsobu, jak ř́́dil školu. Ředitel stanovil konkrétní požadavky na práci učitelů, monitoroval jejich postup, poskytoval jim zpětnou vazbu, povzbuzoval je. Pečoval o rozvoj mezilidských vztahů v učitelském sboru, pořádal výjezdní zasedání, které bylo věnováno bilancování dosavadního postupu.

Př́ípadová studie stavěla na pohledu učitelů, kteří oceňovali, že je možné dosáhnout změn $\mathrm{k}$ lepšímu na venkovské škole, kde sice převládají žáci z chudších vrstev, ale dosahují vynikajících výsledků v učení a chování. Učitelský sbor školy (pod vedením aktivního ředitele) zlepšil vztahy uvnitř sboru, vztahy učitelů k žákům a dosáhl vysoké úrovně vnímané zdatnosti celého učitelského kolektivu. 
$3 /$

\section{TRENDY A MOŽNÝ BUDOUCÍ VÝVOJ VE ZKOUMÁNÍ SELF-EFFICACY}

Pokud vezmeme polovinu 70. let 20. století za období vzniku Bandurovy teorie self-efficacy, pak má tento pojem za sebou už 45 let vývoje. ${ }^{4}$ Teprve před téměř dvaceti lety však napsal Henson realisticky, že pojem self-efficacy je už připraven opustit období adolescentních obav a přejít do mladé dospělosti (Henson, 2002). 0 devět let později Klassen, Tze, \& Betts et al. (2011) nadepsali svůj přehledový článek o self-efficacy u učitelů otázkou: Známky pokroku, nebo nesplněný slib? Jinak řečeno: jisté zlepšení se rýsuje, ale oproti očekávání jde vše mnohem pomaleji, než se předpokládalo a než by bylo třeba.

Co tedy v roce 2011 přehledová studie Klassena et al. o vnímané vlastní zdatnosti učitelů konstatovala? Oproti období 1986-1997 se v letech 1998-2009 statisticky významně zvýšil počet publikovaných článků věnovaných vnímané vlastní zdatnosti učitelů a zejména počet článků v časopisech s náročným recenzním řízením. Celkem bylo analyzováno 218 článků s empirickým zaměřením. Pokud jde o metodologické přístupy, většina studií používala kvantitativní přístup (76 \%), ryze kvalitativní přístup byl použit v $9 \%$ případů a smíšený přístup v 15 \% případů. Naprostá většina kvantitativních studií (81 \%) měla jednorázový charakter, byla tedy transverzální. Longitudinální studie byly zastoupeny $9 \%$ případů a kvaziexperimentální a experimentální studie byly zastoupeny jen $6 \%$. Přitom je zřejmé, že longitudinální výzkum je pro badatele náročný na čas, na organizační, materiální a finanční zajištění, na udržení zkoumaného souboru učitelů pohromadě, poskytuje

4 Klíčový článek A. Bandury (1977). Self-efficacy: Toward a unifying theory of behavioral change. Psychological Review, 84(2), 191-215 má ke konci července 2020 podle Googlu Scholar už na svém kontě neuvěřitelných 73962 citací. 
neocenitelný vhled do vývoje a proměn učitelovy pedagogické zdatnosti v čase. I když odborníci vědí, jak je důležité poznat zdroje, proměnné, které stojí u zrodu a proměn vnímané pedagogické zdatnosti učitelů, pouze 7 studií z oněch 218 se tomuto problému věnovalo.

Zajímavé jsou také údaje o obsahovém, tj. tematickém zaměření analyzovaných článků. Celkem $60 \%$ se věnovalo obecné vnímané zdatnosti jednotlivých učitelů, dalších $28 \%$ učitelské zdatnosti ve vztahu k některým vyučovacím předmětům (např. př́rodovědné předměty, matematika, tělesná výchova, jazyky) a konečně 12 \% vnímané zdatnosti učitelského kolektivu. Za zmínku stojí rovněž stupně škol, na nichž zkoumaní učitelé působili. Údaje jsme seřadili sestupně podle četnosti případů: 29 \% článků se věnovalo studentům-budoucím učitelům, kteří se na své povolání teprve připravovali; $24 \%$ byly články o učitelích na 1 . stupni základní školy; 15 \% články o učitelích na středních školách, 3 \% články o učitelích na 2. stupni základních škol; dalších $25 \%$ článků popisovalo výzkumy zahrnující učitele z různých stupňů škol. Ve zbývajících článcích byly údaje nejasné.

Další přehledová studie (Lee, Chen, \& Wang, 2017) si svůj záběr zúžila. Nezahrnula všechny publikované články o vnímané pedagogické zdatnosti učitelů, ale pouze ty, jež deklarovaly, že daná škola a její učitelé prosazují ve své práci výuku zaměřenou na žáka. Jednalo se o články z let 2009-2016. Celkem autoři analyzovali 34 článků s empirickým zaměřením. Pokud jde o metodologické přístupy, většina studií používala kvantitativní př́stup ( $47 \%$ ), ryze kvalitativní přístup byl použit v $24 \%$ př́ípadů a smíšený přístup v $29 \%$ případů. Tematické či oborové zaměření bylo podobné jako $\mathrm{v}$ předchozí přehledové studii: vnímaná pedagogická zdatnost učitelů se týkala v $53 \%$ prŕpadů př́rodověd ných předmětů a matematiky, v $9 \%$ prŕípadů tělesné výchovy a $6 \%$ případů jazyků. Zbytek (32\%) tvořily případy, kdy šlo o učitele vyučující několik předmětů nebo údaje nebyly uvedeny. Pokud jde o stupně škol, na nichž zkoumaní učitelé působili, vzniklo toto pořadí: $38 \%$ př́padů učitelé na 1 . stupni základní školy, $24 \%$ učitelé na 2 . a 3. stupni škol, $6 \%$ učitelé mateřských škol; zbytek (32 \%) byly př́ípady, kdy šlo o učitele z různých stupňu škol nebo potřebné údaje chyběly.

Hlubší analýza článků identifikovala šest tematických okruhů, jimiž se badatelé hlouběji zabývali. Jednalo se o vztah vnímané vlastní pedagogické zdatnosti učitele k:

- učitelovým zkušenostem s aktivním a úspěšným zvládáním úkolů, anebo se zprostředkovaným získáváním zkušeností pomocí observačního učení či sledováním videozáznamů důležitých pedagogických situací;

- učitelovým pozitivním emocím typu spojenost, radost, hravost;

- učitelovým zdrojům zdatnosti, jež jsou učiteli dostupné: např. dostatek času, vhodné studijní materiály, možnost konzultací; 
- učitelovým znalostem obsahové stránky výuky (učiva), jeho didaktickým znalostem obsahu a znalostem zvláštností žáků;

- učitelovým pozitivním postojům $\mathrm{k}$ výuce zaměřené na žáka, jistotě v řízení třídy, v užití vyučovacích strategií (např. kooperativního vyučování);

- úvahám o možném praktickém využití výuky zaměřené na žáka (rozumí se tím situace, kdy začínající učitel zvažuje, že tento systém zavede do své výuky, nikoli případy, kdy se tak děje hromadně u učitelů dlouhodobě působících na škole).

Svůj přehledový článek autoři uzavírají upozorněním na tři výhledové směry bádání. Za prvé: při výzkumu vnímané vlastní zdatnosti učitelů bude třeba brát mnohem více v úvahu učitelovy znalosti; zejména pak jeho znalosti obsahu (učiva), dále didaktické znalosti obsahu a znalosti zvláštností žáků. To se dosud neděje. Za druhé: nelze studovat jen osobní způsobilost aktérů a úkoly, které řeší; je třeba mnohem pečlivěji zkoumat okolnosti, podmínky, krátce řečeno kontext, v němž učitelé a žáci ve škole fungují. Za třetí: dosavadní výzkumy jdou převážně po individuální linii (učitelovy osobní zkušenosti, osobní emoce, osobní pedagogické názory na výuku); to, co chybí, je vliv sociálních vztahů na rozvoj vnímané vlastní zdatnosti učitelů a důkladnější výzkumy vnímané zdatnosti pedagogických sborů.

Dalším tematickým zúžením problematiky vnímané vlastní zdatnosti učitelů byla meta-analýza, která sledovala vztah této proměnné k vyhoření učitelů (Aloe, Amo, \& Shanahan, 2014). Z celého spektra vnímaných vlastních pedagogických zdatností učitele si autoři zvolili zdatnost učitele při řízení tř́idy; učitelovo vyhoření operacionalizovali všemi třemi složkami, tj. emočním vyčerpáním, depersonalizací a sníženou osobní výkonností. Analyzovali 16 výzkumů z let 1985-2012, které zahrnuly učitele od předškolních zařízení po střední školy.

Vztahy mezi zdatností učitele při řízení třídy a všemi třemi složkami učitelova vyhoření byly statisticky významné. Nejtěsnější negativní vztah byl mezi zdatností učitele při řízení třídy a nízkou osobní výkonností učitele. Druhý (poněkud slabší) byl negativní vztah mezi zdatností učitele při řízení třídy a emočním vyčerpáním a třetí (ještě slabší negativní vztah) byl mezi zdatností učitele při řízení třídy a depersonalizací. Jinak řečeno: když se snižuje učitelem vnímaná vlastní zdatnost při ř́zení třídy, zhoršuje se učitelova osobní výkonnost, zvyšuje se pocit emočního vyčerpání a zhoršuje se pocit depersonalizace. A naopak: pokud se zvyšuje pocit vnímané osobní zdatnosti při řízení třídy, učitel se cítí lépe a je výkonnější.

Autoři výzkumu zkoumali také některé okolnosti, které by mohly ovlivnit získané výsledky. Konstatovali, že získané výsledky souvisejí se stupněm školy, na němž zkoumaní učitelé působí, a také s typem dotazníku učitelova vyhoření, jenž byl ve výzkumu použit (přesněji řečeno s počtem položek, které dotazník 
obsahoval). Získané výsledky naopak nesouvisely se zemí, v níž byl výzkum prováděn, s podílem žen ve zkoumaném souboru vyučujících, ani s rokem, v němž byl výzkum uskutečněn.

Mnoho výzkumů se věnovalo hledání odpovědi na jednoduchou otázku: proč si někteř́ žáci a někteří učitelé důvěřují, jsou sebevědomější, nemají obavy ze svého selhání, zatímco jiní ano? A to mluvíme o rozdílech uvnitř jedné země. Existuje něco podobného i mezi různými zeměmi? Jeon (2018) se domnívá, že neexistuje žádný teoretický důvod, proč by se vnímaná vlastní zdatnost učitelů v různých zemích neměla lišit. Odkazuje přitom na autoritu A. Bandury, který napsal, že systém přesvědčení o vnímané zdatnosti člověka není nějakým globálním rysem, ale diferencovaným souborem různých přesvědčení, které jsou spojeny s odlišnými sférami fungování člověka (2006 b, s. 307).

Dříve, než se zastavíme u dosavadních srovnání proměnné „vnímaná vlastní zdatnost" u učitelů z různých zemí, musíme připomenout, že tuto proměnnou je třeba nějak změřit. Obvyklým nástrojem mezinárodního srovnávání jsou dotazníky, které se snaží tuto proměnnou co nejlépe operacionalizovat. V mezinárodních srovnáních se nejčastěji setkáváme se třemi dotazníky:

- Teaching and Learning International Survey (TALIS). Je to dotazník o učitelích, výuce a prostředí, v němž vzdělávání probíhá. Tvorba dotazníku a jeho využívání jsou podporovány OECD. Dotazník TALIS má dvě podoby: mezinárodní dotazník pro učitele (43 položek) a mezinárodní dotazník pro ředitele škol (37 položek). Zjišțují mj. zázemí těchto pedagogických pracovníků, pracovní prostředí, profesní rozvoj, jejich přesvědčení o své pedagogické zdatnosti a jejich postoje $\mathrm{k}$ výuce. Je určeno pro úroveň ISCED 2 (nižší sekundární stupeň školy, tj. přibližně 6.-10. ročník). Tento dotazník byl poprvé použit v roce 2008 a zadává se v pětiletých intervalech (zatím byl použit v letech 2013,2018).

- Norwegian Teachers'Sense of Self-Efficacy (NTSES) (Skaalvik, \& Skaalvik, 2007). Jde o dotazník pro učitele, který má 24 položek a je strukturován do 6 subškál: Výuka; Adaptování edukace individuálním potřebám žáků; Motivování žáků; Udržování kázně; Spolupráce učitele s kolegy a s rodiči; Zvládání změn a výzev.

- Ohio State teacher efficacy scale (OSTES). (Tschannen-Moran, \& Hoy, 2001). Jde o dotazník, který existuje ve dvou verzích - plné (24 položek) a zkrácené (12 položek). Je určen učitelům a je strukturován do 3 subškál: učitelem vnímaná vlastní zdatnost pro používání výukových strategií; učitelem vnímaná vlastní zdatnost pro řízení tř́ídy; učitelem vnímaná vlastní zdatnost pro motivování žáků k angažovanosti ve výuce.

Dủležitou odbornou otázkou je, zda nástroje měřící učitelem vnímanou vlastní pedagogickou zdatnost mohou mít univerzální podobu, anebo musí být specifické 
pro jednotlivé země. Zdá se, že takto kategoricky formulovaná otázka nemá jasnou odpověd', nebot' problematiku zjednodušuje do podoby „Vše, nebo nic“. Věcná odpověd' zní, že část dotazníkových položek může být společná pro řadu zemí, ale některé položky musí brát v úvahu specifika určité skupiny zemí. Například dotazník Norwegian Teachers'Sense of Self-Efficacy je koncipován tak, že tři ze šesti subškál přidávají prvky, které jsou specifické pro jednotlivé země. Jde o subškály: Výuka, Motivace žáků a Udržování kázně.

Jedním z užitečných vodítek, jak porozumět sociokulturním rozdílům, může být koncepce nizozemských autorů (Hofstede, \& Hofstede, 2006), kteří rozlišili pět dimenzí národní kultury, jimiž se obyvatelé různých zemí liší. Jsou to: mocenský odstup, vyhýbání se nejistotě, individualismus-kolektivismus, maskulinita-feminita a dlouhodobá-krátkodobá časová orientace. Nebudeme je zde probírat všechny, vybereme jen ilustrativní př́íklady.

Výše zmíněný mezinárodní dotazník TALIS byl poprvé administrován v roce 2008. Jeon ve své práci z roku 2018 doložil rozdíly mezi 22 zeměmi v úrovni průměrné vnímané pedagogické zdatnosti učitelů ve 22 zemích. (Dodejme, že učitelé v dotazníku hodnotili sami sebe, nešlo tedy o vnější hodnocení.) Získané údaje byly agregovány do jednoho ukazatele za jednu zemi, a to tak, že výsledný údaj měl podobu z-skóre s průměrem nula a směrodatnou odchylkou jedna. Výsledkem srovnání byl graf, v němž nejvyšší vnímanou zdatnost svých učitelů mělo Norsko $(+0,51)$, nejnižší zdatnost na druhém konci škály měla Jižní Korea $(-0,71)$. Je však třeba ř́ci, že nemusí jít o reálný stav v úrovni vnímané zdatnosti učitelů, ale ve hře mohou být sociokulturní zvláštnosti. Např. Jižní Korea, jako země s konfuciánskými tradicemi, preferuje skromnost lidí, takže uvádění toho, že je člověk v něčem dobrý, nebývá společensky přijatelné.

Jiný př́́klad:v práci (Vieluf, Kunter, \& Vijver, 2013) autoři zjistili negativní vztah mezi uváděnou pedagogickou zdatností učitelů a jejich př́slušností k zemi, v níž převládá kolektivistická kultura. Kolektivistické kultury totiž vyžadují určitou loajalitu ke skupině, preferují skupinové cíle, nikoli cíle individuální, individuální vyniknutí a individuální úspěšnost. Jedinec by (podle mínění ostatních) neměl prezentovat sám sebe. Není proto divu, že bývá opatrný při uvádění své profesionální zdatnosti. Tento pohled autoři zobecnili: kulturní normy a společensky akceptované či naopak odmítané hodnoty ovlivňují sebeprezentování jedinců. Převládá-li ve společnosti jako norma skromnost (nebo naopak prezentování svých předností) má to vliv na nadnárodní rozdíly ve vnímané vlastní zdatnosti učitelů. Vliv sociokulturních faktorů bude malý v rámci jed né země, ale výraznější v mezinárodních srovnáních.

Po těchto konkrétních příkladech shrneme hlavní vývojové trendy. Soudobé výzkumy vnímané vlastní zdatnosti učitelů a žáků naznačují, že: 
- v literatuře převládá výrazný zájem o vnímanou zdatnost žáků/studentů nad vnímanou zdatností učitelů;

- těžiště výzkumů je zemích Severní Ameriky (USA, Kanada), druhá v pořadí je Evropa, třetí je Asie a čtvrtá Oceánie;

- existují určité sociokulturní rozdíly, které ovlivňují výsledky zjištování vnímané vlastní zdatnosti u žáků a učitelů, třebaže je snaha používat pro srovnávání v různých zemích (pokud možno) stejné dotazníky;

- stále převažují kvantitativní, především dotazníkové metody; na druhém místě je smíšený výzkum a na třetím ryze kvalitativní výzkum;

- převažují transverzální výzkumy, ale přibývají výzkumy longitudinální;

- dominují explorativní výzkumy; jen málo je zatím výzkumů kvazi-experimentálních a experimentálních;

- pokud jde o učitele, výzkumy se nejčastěji odehrávají u studentů-budoucích učitelů, kteří se na své povolání teprve připravují; druzí v pořadí bývají učitelé na 1. stupni základní školy; na třetím místě bývají učitelé středních škol; nově se objevuje výrazný zájem o studenty a učitele vysokých škol (viz fakulty lékařské, ošetřovatelské, inženýrské) a učitele v předškolních zařízeních;

- u učitelů v činné službě nejde jen o jejich vnímanou pedagogickou zdatnost, která se projevuje během výuky; zvyšuje se zájem o to, nakolik jejich další vzdělávání a kurzy profesního rozvoje zlepšují jejich vnímanou profesní zdatnost;

- pozvolna se snižuje dosud dominantní zájem o obecnou vnímanou zdatnost osob a přibývá zájem o oborově a tematicky specifickou zdatnost (v přírodovědných předmětech, v tělesná výchově, $v$ jazycích; $u$ učitelů je zájem o jejich počítačovou gramotnost);

- vnímaná vlastní zdatnost u učitelů i žáků nemá charakter jednoho homogenního konstruktu, ale je multidimenzionální; sestává z řady dílčích složek, faktorů, které lze měřit;

- vnímaná vlastní zdatnost u učitelů i žáků nemá podobu jedné univerzální, trans-situační charakteristiky, nýbrž je situačně specifická (závisí na typu řešených úkolů a na podmínkách, v nichž se vše odehrává) a mění se v čase (může se zlepšovat i zhoršovat);

- vše, co jsme doposud uvedli, se týká vnímané osobní, tedy individuální zdatnosti; teprve v posledních letech začíná úsilí důkladněji propracovat ideu kolektivní zdatnosti, zejména učitelských sborů.

V čem lze vidět přínos ve sledování self-efficacy u učitelů? Zvyšování vnímané pedagogické zdatnosti u učitelů vede podle dosavadních výzkumů k tomu, že učitelé, kteří si veří, jsou odborně zdatní a mají dobré pedagogické výsledky, nejsou obvykle náchylní k vyhoření či k odchodu z profese (Jeon, 2018). Zvyšování pedagogické 
zdatnosti učitelů zpravidla vyústí ve zlepšování jejich pedagogických výsledků. Není tedy divu, že tvůrci vzdělávací politiky v zahraničí a zahraniční badatelé vidí jako jednu z cest k poskytování kvalitního vzdělávacího prostředí pro všechny děti právě kultivování a rozvíjení vnímané pedagogické zdatnosti učitelů (Guo, Justice, \& Sawyer et al. 2011).

Příspěvkem ke sledování self efficacy budoucích učitelů i učitelů začátečníků je právě naše monografie. $V$ následujících kapitolách představíme vlastní výzkumy, věnované právě pregraduální př́ípravě učitelů. 

4/

\section{VÝZKUMY SELF-EFFICACY A PREGRADUÁLNÍ VZDĚLÁVÁNÍ UČITELŮ}

Zahraniční výzkumná bibliografie potvrzuje, že ve světě vnikají badatelské práce o výzkumech self-efficacy u specifické respondentské skupiny, kterými jsou studenti vysokých škol, zejména pak budoucí učitelé. Bližším pohledem ale zjistíme, že nemají systematickou a prohlubující se tendenci, ba naopak. Popisované výzkumy jsou typu „ad hoc“ a obvykle se zaměřují na parciální výzkumná témata, která jsou popisována jako „příklady šetření“. Uvádíme kupříkladu práce Vrielinga, Bastiaensa, \& Stijnena (2010), Kamaliho, Raudenbushe, \& Bhumirata (1992), či Chana (2008). Z nám blízkého prostoru se výzkumem SE v podmínkách studentů učitelství zabývali mimo jiné Majerčíková et al. (2012), nebo Gavora, \& Majerčíková (2012), samostatně pak Gavora v pracích z let 2010, 2011 a 2012.

Z relativně malé množiny výzkumných prací, jež se zaměřují na poznávání self-efficacy u budoucích učitelů, je o to méně výzkumů, jež jsou zaměřeny na studující prvního ročníku. Nemnohé studie reprezentují díla např. Pendergasta, Garvise, \& Keogha (2011), či Wennera (2001). Že se někdy jedná o specifické badatelské téma, dokazuje práce Dalgetyho a Colla (2006), nebo Cooka (2013), v jejichž centru pozornosti byli studenti prvního ročníku př́írodovědných oborů a výzkum osobně vnímané zdatnosti byl zaměřen na jejich ambice pracovat v budoucnu na výzkumných úkolech a stát se vědeckými pracovníky. Na otázku, jak ovlivnit studentskou self-efficacy, odpovídají ve svém příspěvku Van Dinther, Dochy, \& Segers (2011). Hlavní hybné možnosti spatřují především v celkové koncepci vysokoškolského studia, resp. v pojetí, obsahu a metodách studijních programů. Jako poslední příklad zájmu badatelů o začínající studenty uvedeme studii Ozana, Gundogdua, \& Celkana (2012), jejímž záměrem bylo zjištění vztahu mezi strategií učení začínajících studentů a jejich studijní úspěšností. 
Mezi zajímavé skutečnosti patř́í, že i v českém akademickém prostředí lze nalézt graduační práce, které se zabývají teorií i empirickým poznáváním fenoménu self-efficacy. Připomeňme některé: Indráková (2011) se zajímala o vztah mezi SE a časovou perspektivou u vzorku adolescentní mládeže, a to v konfrontaci české a americké populace. Pracovala se dvěma, na české prostředí adaptovanými, dotazníky a dospěla mimo jiné k závěrům, že čeští respondenti jsou více orientováni na budoucnost, na rozdíl od amerického vzorku. Nicméně z „globálního pohledu“ se neprokázal statisticky významný rozdíl mezi oběma kulturami.

O vztahu mezi self-efficacy a sebehodnocením pojednávala diplomová práce Hebronové (2014). Byla zaměřena na popis a zkoumání hodnocení žáků základní školy, u nichž se projevila osobitá podoba individuálně vnímané zdatnosti. Výzkumným nástrojem byl do čtyř částí strukturovaný dotazník, z větší části přeložený a upravený na české prostředí. Respondentský vzorek zahrnoval množinu žáků různých typů základních škol - včetně malotřídek. Data byla statisticky zpracována jednofaktorovou analýzou. K jakým výsledkům autorka dospěla? Mimo jiné se neprokázal vztah mezi mírou SE a orientací školy na soustavné sebehodnocení vzdělávaných. Obdobně nebyla zjištěna statisticky významná vazba mezi mírou self-efficacy a studijní úspěšností žáka (resp. studijním úspěchem).

Self-efficacy v matematice u žáků a žákyň prvního stupně základní školy bylo téma, které si pro svou bakalářskou práci zvolila Vozková (2014). Její práce se zabývala specifickou oblastí self-efficacy, a to v matematice a dalšími s ní spojenými proměnnými (postoje, výkon a vztahy mezi pohlavími). Po teoretickém úvodu následovala empirická část, jejímž záměrem bylo zjistit míru matematické self-efficacy, a případné rozdíly v ní, mezi žáky a žákyněmi 4. ročníku ZŠ. Výzkumnými nástroji byly dva dotazníky a svépomocně sestavený matematický test. Pohledem výsledků se ukázalo, že nebyly identifikovány rozdíly mezi žáky a žákyněmi v matematické self-efficacy, jen u chlapců byl (očekávaně) zjištěn pozitivnější vztah k matematice jako př́rodní vědě.

Zajímavou aplikaci myšlenek o osobně vnímané zdatnosti zkoumala ve své diplomové práci Mlynářová (2015). Zajímala se o vztah mezi SE a sportovními výkony, konkrétně v plaveckém sportu, u dětí a dospívajících. Její text, kromě obvyklých teoretických pasáží, obsahuje také popis způsobů měření self-efficacy, a to především dotazníkovými nástroji s následnou statistickou analýzou. Ostatně i takto postupovala v empirické části své závěrečné práce, ve které „nasadila“ dva standardizované dotazníky; jeden zjišt’oval míru SE ve vztahu k fyzickému výkonu a druhý měřil předzávodní úzkost sportovců. $Z$ výsledků mimo jiné vyplynulo, že nebyl diagnostikován podstatný vztah mezi úrovní SE a objektivním sportovním výkonem, nicméně se prokázalo subjektivní prožívání výkonnosti (i ve vztahu k předzávodní úzkosti). 
Jako př́́klad řešení tématu self-efficacy u jiné respondentské skupiny, než jsou žáci a pedagogové, může posloužit diplomová práce Pustinové (2019). Autorka se zaměřila na popis a zjišt'ování self-efficacy u pracovníků v pomáhajících profesích. Po teoretických pasážích o vlivu SE na člověka, faktorech, které ovlivňují profesní výkon pracovníků v sociální sféře, se diplomantka zaměřila na výzkumnou část. Zkoumala metodou polostrukturovaného rozhovoru mezi pečovateli jejich vztah k profesi, k obtížím na počátku profesní dráhy, zajímala se o vliv klientů na každodenní práci a konečně i na to, jak sami sebe vnímají pracovníci jako vykonavatele sociálně orientovaného zaměstnání. Výsledky potvrdily náročnost sociálních profesí, ale také odhodlání pečovatelů se s danými obtížemi „poprat“ a v profesi zůstat. Překvapivě však autorka zjistila nezájem o kariérní postup a nezájem o dlouhodobou životní orientaci.

Letmý exkurz do akademického prostředí, coby zdroje studentských prací o self-efficacy, zakončíme třemi odkazy spolupracující vysoké školy. Na Pedagogické fakultě v Hradci Králové jsou práce tohoto typu spojeny se jménem tehdejšího studenta Marka Linke. Tématu osobně vnímané zdatnosti se týkala jak jeho bakalářská práce (2014), tak i závěrečná diplomová práce (2016). 0 dlouhodobosti zájmu svědčí i to, že se Linke představil s tématem SE na studentských prezentačních akcích, např. na Fóru mladých výzkumníků v roce 2013.

Linkeho bakalářská práce (2014) byla cílena mezi začínající studenty učitelství a jejím záměrem bylo zjistit, jak o tématu osobně vnímané zdatnosti uvažují začínající vysokoškoláci, nakolik jsou schopni koncept SE pochopit a porozumět mu, individuálně ho vztáhnout ke své osobě na základě sebepoznání a sebereflexe. Výzkumný zájem se dále soustředil na jejich názory ohledně možností rozvíjet záměrně self-efficacy u (budoucích) učitelů a zprostředkovaně i u jejich žáků. Výzkumným nástrojem bylo (podle Gavory) interview v ohniskové skupině (focus group) a následná analýza verbální i mimoslovní komunikace $\mathrm{z}$ audiovizuálního záznamu. Rozbor byl uskutečněn prostřednictvím otevřeného a axiálního kódování, jež spadá do procedury zakotvené teorie (Strauss, \& Corbinová, 1999).

0 této práci se více na tomto místě nebudeme rozepisovat, protože její průběh a výsledky - spolu s dalšími navazujícími výzkumnými sondami jsou bezprostředně popsány ve výzkumné části této kapitoly.

Diplomová práce (Linke, 2016) měla některé podobné designové rysy jako práce bakalářská. Rovněž mířila mezi začínající studenty a zajímala se o jejich postoje k obecnému pojetí self-efficacy, i k individuálnímu pojetí vnímané osobní zdatnosti. Odlišná však byla metodologie, která vycházela z nestandardizovaného dotazníkového šetření mezi 1. ročníky, které bylo zakomponováno do struktury teoretické pedagogické přípravy v raném stádiu přípravného vzdělávání. Kvantitativní šetření přineslo své výsledky a mezi hlavní patřilo zjištění, že respondenti 
o fenoménu SE uvažovali ve čtyřech mezi sebou vázaných úrovních: nejprve jako o porozumění konceptu, poté jako o zosobnění ke své osobě, někteří rozvíjeli myšlenky o vztahu SE k blízkému sociálnímu prostředí, a konečně část respondentů uváděla i možnost záměrně intervenovat do poznávaného tématu tak, aby bylo dosaženo hlubších souvislostí.

Konstatujeme, že jakkoliv je vztah konceptu self-efficacy a studentů v počátku učitelské profesionalizace zajímavý, je o něj jen sporadický výzkumný zájem, který přináší jen dílčí poznání. 
5/

\section{SELF-EFFICACY V GENEZI PEDAGOGICKÉHO PROFESNÍHO VÝVOJE}

Exkurz do dostupných pedagogicky orientovaných literárních zdrojů jednoznačně napovídá, že autorský zájem o fenomén self-efficacy je spojován s pedagogy v aktivní učitelské službě.

Podle očekávání se ukazuje, že podoba self-efficacy bude různá podle toho, kdo ji prochází, resp. v jaké profesní etapě vývoje se člověk v roli učitele nachází. Z obvyklé typologie je zřejmé, že jinak o svých o své self-efficacy bude přemýšlet vyučující-začátečník, a jinak učitel, který se nachází v expertním stádiu své profesionality. 0 tom, jak se může v závislosti na profesním vývoji měnit self-efficacy, se zamýšlíme v tab. 5.1.

Výzkumy profesní zdatnosti u pedagogů v rozličných etapách profesního vývoje přinášejí mnohdy nesouměřitelné výpovědi, nicméně je spojuje podobnost v tom, že uvažují v rámci již známého prostředí, již nabitých osobních zkušeností, již v praxi ověřených psycho-didaktických a výchovných procedur, kterými prošli a měli možnost je osobitě prožívat a reflektovat.

Jak ale mohou o své pedagogické kondici uvažovat ti, kteří nemají bezprostřední pedagogické zkušenosti, nebo prožili jen skromné příležitosti k vyučování (resp. prošli minimální pedagogickou praxí) a mají jen malou (nebo nezbytnou) teoretickou (oborově vědní, pedagogicko-psychologickou, psycho-didaktickou) oporu? Jak o self-efficacy budou uvažovat budoucí učitelé, kteří navíc nejsou obvykle schopni dospět k ustálenému sebepojetí a pojetí budoucí profese?

- Budou k dispozici vhodné metodologické nástroje k tomu, aby respektovaly pozici „budoucího učitele“ a zároveň přinesly taková data, která se očekávají?

- Budou tito respondenti ve vhodně nastavených výzkumech o self-efficacy schopni vůbec porozumět klíčovému pojmu a jeho pojetí? 


\begin{tabular}{|c|c|c|c|c|}
\hline $\begin{array}{c}\text { Profesionalizační } \\
\text { etapa } \\
\text { (v retrospektivě) }\end{array}$ & $\begin{array}{c}\text { Charakteristika } \\
\text { základní } \\
\text { orientace }\end{array}$ & $\begin{array}{l}\text { Profesně-didak- } \\
\text { tické jednání } \\
\text { a tendence }\end{array}$ & $\begin{array}{c}\text { Rozvojové prvky } \\
\text { a opora }\end{array}$ & $\begin{array}{l}\text { Klíčové zdroje } \\
\text { self-efficacy } \\
\text { (chování, osob- } \\
\text { nost, prostředí) }\end{array}$ \\
\hline $\begin{array}{l}\text { REFLEXIVNí } \\
\text { (pedagog } \\
\text { v závěru aktivní } \\
\text { činnosti) }\end{array}$ & $\begin{array}{l}\text { Profesní bilanco- } \\
\text { vání, subjektivní } \\
\text { zpětné „traso- } \\
\text { vání“ profesních } \\
\text { etap, narativní } \\
\text { retrospektiva }\end{array}$ & $\begin{array}{l}\text { Edukační čin- } \\
\text { nost relativně } \\
\text { nezávislá na } \\
\text { vnějších vlivech, } \\
\text { celistvé působení } \\
\text { „lámané“ přes } \\
\text { nahromaděné } \\
\text { zkušenosti, po- } \\
\text { stoje, predikce }\end{array}$ & $\begin{array}{l}\text { Učitelovo po- } \\
\text { jetí vyučování, } \\
\text { mezioborové } \\
\text { obohacení } \\
\text { a transprofesní } \\
\text { přesahy, kulturní } \\
\text { a jiné inspirace, } \\
\text { redefinice kvality } \\
\text { života }\end{array}$ & $\begin{array}{l}\text { Rozhodující zna- } \\
\text { lost své osobnosti } \\
\text { a ověřené jednání } \\
\text { v nahromaděných } \\
\text { zkušenostech, } \\
\text { latentní význam } \\
\text { prostředí }\end{array}$ \\
\hline $\begin{array}{l}\text { KONVERGENTNÍ } \\
\text { (sbližování } \\
\text { a optimalizace } \\
\text { procesů učení } \\
\text { a vyučování) }\end{array}$ & $\begin{array}{l}\text { Ustálení profes- } \\
\text { ního a sociálního } \\
\text { jednání, zrod } \\
\text { relativně stálé } \\
\text { osobní profesní } \\
\text { „filozofie“, učitel } \\
\text { expert }\end{array}$ & $\begin{array}{l}\text { Bohatá mentál- } \\
\text { ní, dovednostní } \\
\text { a „akční“ sít’ vzor- } \\
\text { ců jednání a pů- } \\
\text { sobení sbližující } \\
\text { procesy vyučová- } \\
\text { ní a učení... }\end{array}$ & $\begin{array}{l}\text { Dlouhodobá refle- } \\
\text { xe, stabilizovaná } \\
\text { profesní identita, } \\
\text { sebereflektovaní } \\
\text { zrání, bilance } \\
\text { předešlé profesi- } \\
\text { onalizace }\end{array}$ & $\begin{array}{l}\text { Vykalkulované } \\
\text { profesní chování } \\
\text { podle ověřených } \\
\text { situačních vzor- } \\
\text { ců, jen částečně } \\
\text { ovlivněno pro- } \\
\text { středí }\end{array}$ \\
\hline $\begin{array}{l}\text { SOCIÁLNĚ } \\
\text { VZTAHOVÁ }\end{array}$ & $\begin{array}{l}\text { „Objevování“ } \\
\text { sociální dimenze } \\
\text { učitelství, posi- } \\
\text { lování interakce } \\
\text { s empatickým } \\
\text { a sociálně vyzrá- } \\
\text { lým jednáním }\end{array}$ & $\begin{array}{l}\text { Individualizace } \\
\text { působení, prak- } \\
\text { tická sociální dia- } \\
\text { gnostika školního } \\
\text { společenství, hle- } \\
\text { dání vztahu mezi } \\
\text { charakteristika- } \\
\text { mi žáka a cíleným } \\
\text { působením }\end{array}$ & $\begin{array}{l}\text { Obohacování pro- } \\
\text { měnami osobní } \\
\text { sociální role, širší } \\
\text { celospolečenské } \\
\text { vlivy a jejich } \\
\text { transformace } \\
\text { do každodenní } \\
\text { školní reality }\end{array}$ & $\begin{array}{l}\text { Dorovnávání } \\
\text { vlivů prostředí, } \\
\text { a sebepoznání, } \\
\text { úspěšnost svého } \\
\text { chování ověřo- } \\
\text { vána úspěšností } \\
\text { žáků, pružná } \\
\text { podoba chování }\end{array}$ \\
\hline ALTERNATIVNÍ & $\begin{array}{l}\text { Prohlubování } \\
\text { profesionaliza- } \\
\text { ce, překonání } \\
\text { typizovaného } \\
\text { jednání a snaha } \\
\text { po „jiném“ učite- } \\
\text { lování }\end{array}$ & $\begin{array}{l}\text { Záměrné labo- } \\
\text { rování s jinými } \\
\text { postupy, hledání } \\
\text { méně obvyklých } \\
\text { metod a forem } \\
\text { vzdělávání, po- } \\
\text { stupná orientace } \\
\text { na žáka }\end{array}$ & $\begin{array}{l}\text { Kritické a tvůrčí } \\
\text { období, potřeba } \\
\text { dalšího vzdělává- } \\
\text { ní, př́íjem akční } \\
\text { teorie, komunitní } \\
\text { setkávání }\end{array}$ & $\begin{array}{l}\text { Alternativní } \\
\text { chování jako } \\
\text { souběh výsledek } \\
\text { změn sebepojetí } \\
\text { a narůstání vlivu } \\
\text { prostředí }\end{array}$ \\
\hline
\end{tabular}




\begin{tabular}{|c|c|c|c|c|}
\hline $\begin{array}{c}\text { Profesionalizační } \\
\text { etapa } \\
\text { (v retrospektivě) }\end{array}$ & $\begin{array}{c}\text { Charakteristika } \\
\text { základní } \\
\text { orientace }\end{array}$ & $\begin{array}{l}\text { Profesně-didak- } \\
\text { tické jednání } \\
\text { a tendence }\end{array}$ & $\begin{array}{c}\text { Rozvojové prvky } \\
\text { a opora }\end{array}$ & $\begin{array}{l}\text { Klíčové zdroje } \\
\text { self-efficacy } \\
\text { (chování, osob- } \\
\text { nost, prostředí) }\end{array}$ \\
\hline $\begin{array}{l}\text { AUTONOMNÍ } \\
\text { (začínající nebo } \\
\text { méně zkušený } \\
\text { učitel) }\end{array}$ & $\begin{array}{l}\text { Profesní start, } \\
\text { hledání podmí- } \\
\text { nek a nástrojů } \\
\text { pro minimalizo- } \\
\text { vané autonomní } \\
\text { fungování, domi- } \\
\text { nantní oborová } \\
\text { preference }\end{array}$ & $\begin{array}{l}\text { Zakonzervování } \\
\text { teoretických po- } \\
\text { znatků, orientace } \\
\text { na praktickou } \\
\text { edukaci, repetice } \\
\text { ověřených didak- } \\
\text { tických postupů, } \\
\text { prioritou cíle, } \\
\text { postupné hledání } \\
\text { alternativ }\end{array}$ & $\begin{array}{l}\text { Krátkodobá sebe- } \\
\text { reflexe, náčrty } \\
\text { profesní identity, } \\
\text { interakce s pro- } \\
\text { fesním okolím } \\
\text { a přejímání } \\
\text { „cizích" strategií } \\
\text { a postupů }\end{array}$ & $\begin{array}{l}\text { Klíčové sebepo- } \\
\text { jetí, orientace na } \\
\text { záměry vzdělá- } \\
\text { vání, inspirace } \\
\text { „cizí“ pedago- } \\
\text { gickou činností, } \\
\text { projekce sebe } \\
\text { sama do budoucí- } \\
\text { ho jednání }\end{array}$ \\
\hline
\end{tabular}

Tab. 5.1: Náčrt profesionalizačních etap a klíčové zdroje self-efficacy

- Budou schopni nalézt takové komunikační prostředky, aby vyjádřili své současné přesvědčení o budoucím jednání?

- Bude možné výzkumná data strukturovat, dále analyzovat a třeba i uvažovat o různých úrovních SE v závislosti na etapách učitelského vzdělávání?

Otázky tohoto typu jsou zásadní pro naše sdělení a naším záměrem je alespoň částečně přispět k rozvoji tématu self-efficacy hledáním adekvátních odpovědí. Ještě před tím ale považujeme za důležité odpovědět na otázku, zda i v rámci pregraduálního vzdělávání lze nalézt určité vývojové etapy, kterými student učitelství prochází a jak se mění jeho sociální a profesní role? Je to důležité i proto, že v dílčích etapách profesní přípravy lze očekávat i jiné podoby osobně vnímané zdatnosti (analogicky s obsahem pravého sloupce tab. 5.1.

\section{1}

\section{Pregraduální vzdělávání, jeho etapy a gradace}

Proti očekávání se problematice profesního vývoje „uvnitř̆ pregraduálního vzdělávání budoucích učitelů věnuje jen malá pozornost. Jakoby ono „stávání se učitelem“ bylo bez větších zajímavostí, spíše opakujícím se jednotným dějem, bez vnitřně vymezených fází a míst zlomů. Zkušenosti vzdělavatelů „budoucích vzdělavatelü“ však ukazují, že je tomu spíše naopak a že také v učitelské přípravě můžeme nalézt 
etapy, jimiž budoucí pedagogové procházejí a jejichž působením zvyšují připravenost na reálnou školní praxi. Připomeňme některá obecná východiska dnešního pojetí př́ípravného vzdělávání budoucích učitelů:

* jde o gradovaný, dílčími etapami propojený děj, na jehož počátku je začínající student učitelství a na konci absolvent, schopný autonomního pedagogického působení ve školní praxi,

* záměrem je vytvářet pravdivé obrazy o učitelství jako sociálně prospěšné profesi a budovat spoje mezi učitelstvím a osobními predstavami na profesi se připravujícími jedinci,

* pregraduální vzdělávání by mělo vybavit absolventa kompetencemi ve studovaném oboru, s oporou o aplikovatelné znalosti z pedagogických a psychologických věd, s rozvinutými sociálně-komunikativními dispozicemi, znalostmi didaktických a výchovných procedur, bezprostredně využitelných pedagogické praxi,

* stávání se učitelem je spojeno s vnějšími (pozorovatelnými) projevy profesionalizace, ale také s vnitřními (těžko uchopitelnými) projevy, jež vypovídají o osobitém prožívání profesionalizace jednotlivými studenty,

* pregraduální príprava má obvykle trojí tvár̆: teoreticko-oborovou, didakticko-oborovou a praxeologickou,

* s rolí začínajícího studenta učitelství je spojováno jeho sociálně-osobnostní dozrávání, „natáčeni" $k$ budoucí profesi a odhalování svých potencí,

* ve vyšších etapách pregraduálního vzdělávání nabývají na významu promyšlené př́ležitosti $k$ praktickému ověřování získaných teoreticko-oborových znalostí a psycho-didaktických dovedností, a to v systému průběžných a souvislých pedagogických praxí,

* teoreticko-didaktickou připravenost absolvent prokazuje v závěrečných státních zkouškách, výzkumně-metodologickou zralost pak obhajobou závěrečné diplomové práce.

$\mathrm{Na}$ jedné straně rozumíme těmto obecným tezím a chápeme jejich význam, na straně druhé nejsou přímými "návody“ jak koncipovat pregraduální vzdělávání, v jakých etapách a vztazích. Přesto se v literatuře setkáváme s pokusy projektovat profesionalizační linie a vytvářet etapizační modely. K tématu jsme přispěli naší představou, která je zobrazena na obr. 6 (Svatoš, 2013, s. 802) a ke které přidáváme vysvětlení. 


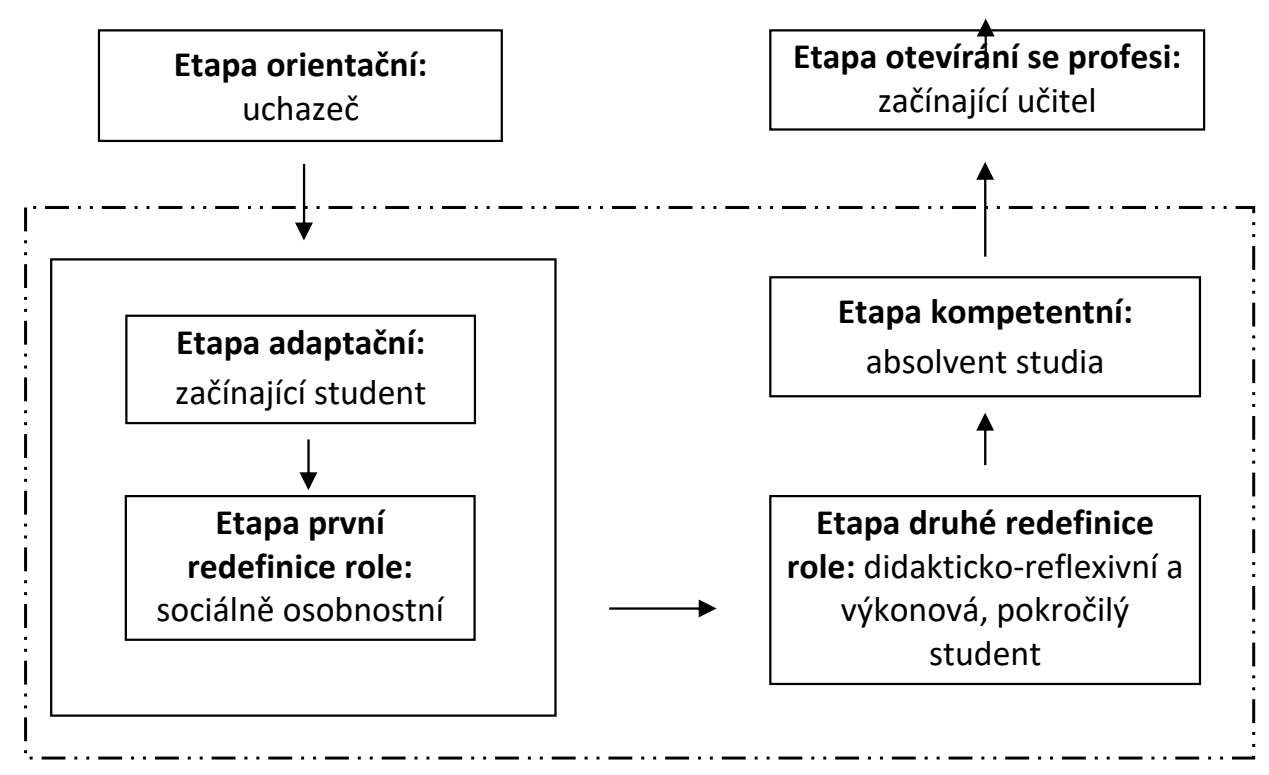

Obr. 6: Představa profesionalizačních etap uvnitř pregraduálního vzdělávání (Svatoš, 2013)

\section{Etapa adaptační: začínající studenti učitelství}

Cíle vzdělávací instituce:

Záměrem je podporovat přijetí role studenta učitelství, vest k porozumění profesionalizační cestě v celém rozpětí studia, nastartovat proměnu uvažování studenta v uvažování budoucího pedagoga, vytvářet primární pedagogicko-psychologickou oporu, připravit podmínky k pozorování školní reality a chápání jejího fungování.

\section{Socializační a profesionalizační indikátory:}

Proměnu role středoškoláka ve studenta vysoké školy často v počátcích provází zřetelná euforie a pochopitelné pozitivní stavy. Při postupném vrůstání do pozice začínajícího studenta se objevují první obtíže, vycházející asynchronního vnímání času; na jedné straně již na studenta působí studijní programy a klima školy, na straně druhé roli studenta na profesionalizačním startu provázejí rezidua z minula i nezkušenosti z adaptace v novém prostředí. 


\section{Etapa první redefinice role: sociálně-osobnostní}

\section{Cíle vzdělávací instituce:}

Cílem je povzbuzovat potřebné síly v profesionalizujícím se jedinci, aby byl zodpovědný za svá studia a studijní výkon, prohlubovat míru pedagogicko-psychologického myšlení, vytvářet most mezi teoretickými oborovými disciplínami a v seminárních aktivitách aplikovanými praktickými zadáními.

\section{Socializační a profesionalizační indikátory:}

„Etablování“ v roli začínajícího studenta učitelství pokračuje zvnitřňováním požadavků, které na něj klade vysoká škola v celistvosti působení. Novost je nahrazována opakujícími se činnostmi, porozuměním vynořujícím se perspektivám a uvažování, za jakých podmínek a při jakém úsilí budou studia dále pokračovat. Zásadně se redefinuje role studenta, a to od jedince jako součásti studijní skupiny, k sebekonstruujícímu jedinci, kolem nějž jsou další osobití jedinci.

Pozn.: v kapitole první monografie jsme věnovali zvýšenou pozornost právě vztahu SE a začínajících studentů učitelských oborů (Svatoš, 2012).

\section{Etapa druhá redefinice role: didakticko-reflexivní a výkonová}

\section{Cíle vzdělávací instituce:}

Záměrem je nastavit oborovou přípravu jako případ aplikované vědy ve školní edukaci, provázat studované obory s didaktickou transformací, vytvářet podmínky pro gradovanou př́ležitost být „, roli učitele“, praxi pojímat jako reflexivní učení - specifické a zároveň typické pro učitelské vzdělávání.

\section{Socializační a profesionalizační indikátory:}

Druhou polovinu učitelských studií provází ověřování budoucí úspěšnosti na základě mikrovýstupové praxe a vyučovacích pokusů v reálných podmínkách školního terénu. Rolovou redefinici doprovází utváření jiného vztahu k přijímané teorii, vznikají didaktické vazby a reálné praktické aplikace. Vývoj profesionalizace je plný nových zkušeností a reflexivního bilancování. Právě autentické výchovné problémy jsou často důvodem pochybností studentů o tom, zda reálnou zátěž budoucího povolání budou zvládat, či nikoliv. Mnohé vypovídá o tom, že jde o období zlomových události s dopady na další profesionalizační vývoj. 


\section{Etapa kompetentní: absolvent studia}

Cíle vzdělávací instituce:

Úkolem je přivést studenta v závěru studia do stavu, kdy je schopen autonomního profesního jednání v jeho očekávaných a akceptovatelných činnostech, vést k bilancování současných možností jako produktu institucionální profesionalizace a seberozvoje, v kognitivně-oborových, psycho-didaktických, sociálně-komunikativních zřetelích, upevnit pozitivní sebeobraz jako podmínky dalšího profesního rozvoje.

Socializační a profesionalizační indikátory:

Student přípravného vzdělávání se stává absolventem po splnění kurikulárních a administrativních podmínek, které vyžaduje studijní program. Raná absolventská uvažování jdou dvěma směry: k reflektování nedávno skončených studií (bilancování zisku a deficitů), současně se vynořují osobní očekávání, prognózy a perspektivy. Osobní hodnoty jsou v mnohém ovlivňovány partnerskými představami a konfrontovány s reálným trhem práce. Hledání uplatnění v profesi mohou doprovázet iluze a deziluze, jistoty a nejistoty, stavy harmonie a disharmonie se školou jako sociálním, profesním i manažerském prostředím.

Jak je zřejmé, členění do dílčích profesionalizačních etap vzniklo především uplatněním kritéria nárůstu praktické schopnosti vzdělávat a vyučovat v podmínkách profesionalizujícího se jedince. V podobném duchu uvažovali i další autoři. Vhodnými, odbornými zdroji, která jsou např. práce Dytrtové, \& Krhutové (2009), Kasáčové (2005), Janíka, \& Havla (2005), Nezvalové (2000), Píšové (2005), Průchy (2002, 2009), Vašutové (2008). Nicméně jde „jen“ o iniciace - bez tvorby uceleného modelu, nebo o velmi obecné teze o učitelském vzdělávání (Spilková, 2008; Marková, \& Urbánek 2008, In Vašutová, 2008), nebo o výňatky ze studijních programů studovaných oborů. Tak např. Lukášová-Kantorková (2003, s. 222-223) popisuje gradační model pedagogických praxí - od hospitačně asistentské až po závěrečnou pedagogickou praxi. Ostatně zaměňování studijních programů za etapy pregraduálního vzdělávání je velmi častým jevem v tuzemské pedeutologické literatuře. 


\section{2}

\section{Význam pedagogické praxe v profesním vývoji budoucího učitele}

Koncepce praktické části přípravy budoucích učitelů není tématem nikterak novým. I z pohledu historie je zjevné, že právě pedagogická praxe byla významným počinem reformátorů československého školství a byla součástí na tzv. učitelských ústavech. Problematika kvalitní přípravy v praxi má kořeny v 19. století. Již v roce 1869 vznikl statut tzv. cvičných škol (viz Maňák, 2002). Důležitou roli v něm zastávali právě cviční učitelé, tedy ti, kteří pomáhali učitelským ústavům připravovat budoucí pedagogy. Postupně se cvičné školy začaly přejmenovávat na školy fakultní i proto, že vznikaly při pedagogických fakultách.

V součásné době je kvalitní příprava budoucích učitelů propojována s mapováním profesních drah učitele, ale také s teoretickým zázemím, které studenti získávají na univerzitách, a rovněž s principy hledání vlastních reflexivních strategií, které mají důležitou roli v procesu profesionalizace učitele. Více než dříve je skloňována role fakultního učitele jako mentora budoucícho učitele.

Fakultní učitelé mají svou představu o dovednostech budoucích učitelů, kterou je v kontextu výzkumu Mazáčové, N. (2002) specifikovat následovně:

- dovednost pracovat s učivem na základě kvalitní znalosti předmětu;

- dovednost vytvořit si vztah k dětem;

- dovednost zaujmout žáky a studenty;

- dovednost efektivně vést vyučovací hodiny;

- dovednost jasného a logického výkladu;

- dovednost předávat znalosti a zkušenosti;

- dovednost pracovat s učivem z hlediska přiměřenosti;

- dovednost operativního přizpůsobení se situaci ve třídě a požadavkům žáků;

- dovednost uplatnit znalosti z pedagogických a psychologických disciplín;

- dovednost být důsledný;

- dovednost komunikovat s žáky a studenty;

- dovednost pracovat s chybou (i vlastní);

- dovednost efektivně organizovat výuku z časového hlediska;

- dovednost rozvíjet neustále svoji osobnost (ochota se stále učit);

- dovednost pohotově reagovat na různorodé situace ve tř́́dě;

- dovednost procvičovat učivo;

- dovednost využít celou škálu metod výuky;

- dovednost získat přirozenou autoritu;

- dovednosti rétorické;

- dovednost předložit jednoduchý a logický zápis učiva. 
I z uvedených výpočtů dovedností, kterými by měl být „obdařen“ budoucí učitel je zřejmé, že předpokladem jsou také osobnostní předpoklady studentů. Významná je tady složka jejich self-efficacy. Již z výzkumu (Wiegerová, A. \& Ficová, L., 2012) víme, že čím vyšší je self-efficacy budoucích učitelů, tím vyšší je předpoklad úspěšného zvládnutí praxe, ale také v budoucnu pozice učitele.

Současná podoba praxe na univerzitách je zaměřena především na to, aby se student orientoval v kurikulárních dokumentech, dokázal zpracovat pedagogické projekty a projektovat vlastní výuku, včetně diagnostiky žáka. Student by měl být veden k reflexi vlastní činnosti i teoretické a praktické interpretaci postupů učitele ve výchovně-vzdělávacím procesu. Podstatné je, aby se studenti postupně naučili rozvíjet strategie kontroly a hodnocení výsledků v učebních činnostech žáků, alternativní, inkluzivní a akulturační specifika nevyjímaje.

Odborných textů k problematice pedagogických praxí existuje v českém diskurzu mnoho (např. Spilková, Tomková, Mazáčová, \& Kargerová et al., 2015, Janík, 2002). Východiskem pro podporu profesní identity, resp. její první etapy, tedy startovací identity budoucích učitelů, je neustále hledání, spolupráce participujících akademických pracovníků a učitelů z praxe. Jádrem přístupu k profesní identitě je vědomá reflexe rozvíjejícího a subjektivního pojetí výuky, pojetí žáka a sebepojetí (Mareš et al., 1996). Profesní identita budoucího učitele má podle Spilkové (2004) tři základní etapy: startovací identitu, proměňovanou identitu a pak výslednou profesní identitu. Pedagogická literatura v posledních letech přináší informace o tom, jak studenti a také začínající učitelé přijímají svoji profesní identitu, jak se utváří a co ji limituje nebo rozvíjí (Dicke, 2015, Kim, \& Cho, 2012, Švaříček, 2011, Wiegerová, \& Gavora, 2014).

Konstrukce profesní identity je celoživotní, neustálý proces. V dětství, v první fázi, se může projevit vytvářením vlastního prekonceptu učitele (Gavora, 2002). Učitelovu profesní identitu ovlivňuje a utváří sociální prostředí. Budoucí učitel si osvojuje normy a hodnoty, interaktivně se socializuje. Je ovlivněn vnějšími podněty ve škole a svými vnitřními faktory, osobní identitou, vlastnostmi a dovednostmi. Zároveň je konstruuje na základě vlastních zkušeností a schopností. Základním předpokladem vývoje profesní identity je sebepoznání, sebeidentifikace, tedy i to, jak jedinec prožívá situace, do kterých se dostává, a také jak ho ovlivňují. Vývoj profesní identity ovlivňuje také přístup společnosti k profesi učitele.

Měnící se systém vzdělávání a učení, nové evropské kurikulární dokumenty mění funkce a cíle vzdělávací politiky evropských zemí. Pro učitele je důležitá profesní jistota, která mu vytváří zázemí pro jeho profesní růst (Spilková, 2010). To se projevuje už při studiu. Profesní jistota je podporována i tehdy, když je práce studenta v průběhu praxe vhodně reflektována. 
Na univerzitách, resp. fakultách v ČR je praxe studentů učitelství převážně členěna na praxi náslechovou, průběžnou a pak souvislou. Zajímavým počinem jiného pohledu na praxe byla koncepce tzv. klinického semestru, která se rozvíjela na Pedagogické fakultě UK v Praze. Různé možnosti podpory reflektování praxe však přinesly i obohacování forem praxí o některé inovace.

Koncepce pedagogických praxí je na univerzitách, které se zaměřují na učitelskou prrípravu, vytvořena jako koherentní propojení předmětů didaktického charakteru s možností jejich aplikace v př́mé činnosti se žáky s důrazem na zapojení studentů do průběžných praxí a následně do vlastních vyučovacích pokusů již od prvního ročníku studia. Nedílnou součástí praxeologické koncepce je vedení studentů k postupné profesní reflexi vlastní připravenosti k výkonu profese. Nově vzniklá struktura studijních předmětů je proto úzce provázaná s praxí, které jsou rozděleny do pěti specifikovaných forem pedagogické praxe. Mezi typické formy pedagogických praxí můžeme zařadit:

a) náslechové praxe,

b) dílčí praktické pedagogické projekty,

c) průběžné praxe,

d) výcvikové praxe,

e) souvislé praxe,

f) tvorbu portfolia praxe a zpracování reflexivního deníku učitele.

Je zcela zřejmé, že náslechová praxe slouží studentům k poznávání prostředí školy, žáků, tříd i učitelského sboru. Jde o dủležitý aspekt praxe studenta. Pro mnohé studenty je prostředí školy v roli budoucího učitele zcela nové. $V$ prŕípadě opakované nebo delší spolupráce (např. při souvislé praxi) by se student měl seznámit se školou jako celkem, posílí to následně vzájemné vztahy, student se bude cítit více vtažený do dění školy. Perspektiva jeho přípravy se posouvá z běžných forem spolupráce směrem k perspektivě zainteresované osoby, což zvyšuje efektivitu přípravy studenta na roli budoucího učitele (Altan, \& Saglamel, 2015). Zajímavé však pro studenty mohou být i tzv. dílčí praktické pedagogické projekty. $\mathrm{V}$ tomhle př́padě se jedná o nespecifickou pedagogickou praxi, která zahrnuje rozličné typy úloh orientovaných na praktickou pedagogickou činnost v rámci teoretických kurzů. Vyučující si například v rámci těchto projektů může zvolit jednorázovou formu hospitace nebo exkurze, během které může doložit své teoretické postuláty prezentované na povinném kurzu. Studenti jsou vedeni ke zpracování dílčích úkolů zadaných vyučujícím studijního předmětu vázaného na praxi a k následné písemné reflexi praxe s rozborem. Vlastní vyučovací pokusy studentů bývají v centru pozornosti průběžné praxe. Jedná se již o specifickou praxi, kde si studenti mohou 
vyzkoušet specializaci na základě jednotlivých didakticky vedených předmětů. Studenti mají možnost úzce spolupracovat a konzultovat s jednotlivými vyučujícími ze základní školy, mají možnosti vyzkoušet si integraci jednotlivých oblastí do celku. Dále mohou provádět hospitační a asistentskou praxi ve výuce vybraných tř́íd základní školy. Studenti jsou vedeni ke zpracování příprav na samostatné výstupy, zpracování reflexe praxe s rozborem a ke zpracování dílčích úkolů zadaných vyučujícím studijního předmětu vázaného na praxi. Realizují a reflektují své první pokusy ve výuce zaznamenané a založené v portfoliu pedagogické praxe (vysvětleno dále v textu).

Na některých univerzitách je mezi pedagogické praxe zařazena i tzv. výcviková praxe. Tato forma nabízí možnost ověření pedagogických strategií v oblasti zájmových činností žáků. Zde patří například i příležitost zapojit se do př́ípravy aktivit zájmových kroužků pro fakultní základní školy. Takto mohou z iniciativy studenta a spolupráce s vyučujícím ze základní školy vzniknout různorodě zaměřené zájmové kroužky, tematické aktivity a projekty nebo činnosti podporující spolupráci s rodiči nebo jinými subjekty školy.

Celková praxeologická příprava studentů, budoucích učitelů, je ukončena souvislou praxí. Její časový horizont je různý a závisí od typu a profilu studijního programu, ve kterém je zakomponována. Souvislá praxe je zpravidla realizována po dobu 4-6 týdnů. Hlavním cílem souvislé praxe je umožnit studentům poznávat prostředí a podmínky školního života v jeho komplexnosti, adaptovat se na každodenní pracovní zátěž a participovat na všech profesních činnostech učitelů.

Studenti se ve vybrané třídě plně zapojují do školního a eventuálně mimoškolního života, asistují učiteli při všech profesních činnostech, včetně mimoškolních aktivitách, seznamují se se všemi formami pedagogické dokumentace apod. Dále studenti hospitují ve výuce, konzultují s třídním učitelem (vedoucím učitelem praxe) postupy plánování, realizace a hodnocení vlastních vyučovacích pokusủ. Studenti jsou dle možností zapojováni do celoškolních akcí, školní družiny, účastní se pracovních porad učitelů a vedení školy, zapojují se do realizovaných forem spolupráce s rodiči. Součástí praxe je příprava portfolia a vedení deníku učitele. V reflexi závěrečné praxe zpracovávají studenti ukázkové portfolium ke státní závěrečné zkoušce. Profesní portfolio praxe je koncipováno jako závěrečné prezenční strukturované portfolio, jehož cílem je prezentace u státní závěrečné zkoušky, reflexe a teoretická obhajoba aplikovaná na problému z pedagogické praxe. Profesní portfolio praxe obsahuje přípravu, realizaci a reflexi závěrečné (souvislé) pedagogické praxe, podklady dílčích praxí, výcvikových i průběžných praxí, pedagogický materiál, didaktický materiál, profesní podklady, evaluaci pedagogické složky praxe, evaluaci didaktické složky praxe, hodnocení učitelů z praxe, stanovisko uvádějících učitelů praxe a vlastní sebehodnocení. Součástí portfolia může být studentem předložený vlastní deník učitele. 
Deník nemá pouze analytickou, didaktickou a pedagogickou hodnotu, ale přináší mnohem více tj. může být i zdrojem podkladů pro kvalitativní designy výzkumů. Deník učitele je osobním dokumentem studenta a slouží k zaznamenávání proběhlých a subjektivně prožitých situací a událostí. Rozdíl mezi portfoliem praxe a deníkem spočívá v tom, že do deníku si student zaznamenává situace, které ho potěšily, překvapily, rozzlobily, ze kterých byl smutný nebo si je nedokáže vysvětlit, chce si je dobře zapamatovat, popřemýšlet o nich, poradit se s někým (na poradě, při přednášce, v článku, v kvalifikační práci) nebo se chce podělit o své nové zkušenosti. Současně si zaznamenává různé nápady, náměty na tvůrčí aktivity, vtipné výroky či historky.

Úspěšné zvládnutí praxeologických požadavků na studenta zvyšuje nebo někdy i oslabuje jeho self-efficacy, jak vysvětlíme dále v textu. 
Již v kapitole 2 jsme se věnovali teoretickému popisu některých metodologických postupů ve výzkumu self-efficacy. V následujících částech se budeme věnovat specificky kvantitativním i kvalitativním přístupům, přičemž jejich uplatnění je součástí kapitoly 7 . V obou př́ípadech byly výzkumným souborem studenti - budoucí učitelé, kteří byli i v procesu své praxeologické přípravy, zprostředkované fakultou, na které studují.

\section{1}

Kvantitativní přístup ke zkoumání self-efficacy učitele: metodologická reflexe

Empirické zkoumání self-efficacy učitele probíhá ve světě minimálně od roku 1980. Od té doby výzkum shromáždil velké množství specifických i obecnějších údajů o tom, jak učitel vnímá tuto svou profesní vlastnost, s čím tato vlastnost souvisí a jak ovlivňuje jeho práci. Výzkum zjistil i to, jak tato vlastnost vzniká a na základě jakých stimulů se rozvíjí. V průběhu let se zkoumání self-efficacy metodologicky rozvinulo a zdokonalovalo, a to na základě řešení problémů, kterým museli výzkumníci čelit při tvorbě výzkumného nástroje, př̀i jeho použití v terénu i při zpracování získaných dat. 


\section{1 .1 \\ Přístup ke zkoumání self-efficacy učitele}

Self-efficacy je vnitřní proměnná. Vyjadřuje to, jak člověk uvažuje o sobě - přesněji, jak věří ve své schopnosti jednat v určitých situacích nebo jako důsledně nebo efektivně je schopen vykonávat určitou činnost. Toto přesvědčení o svých schopnostech se výrazně projevuje v činnosti člověka, v její úspěšnosti, ve volbě cílů (nenáročné, vysoce náročné) a v houževnatosti aktéra Celá řada výzkumů dokumentovala vztah mezi úrovní self-efficacy učitele a náročností jeho činností nebo její úspěšností (Gibson, \& Dembo, 1984; Henson, 2001; Ross, \& Bruce, 2007).

Pozorování činnosti učitele, zjištóvání její náročnosti, efektivity, nebo vlivu na výsledky žáků nedává výzkumníkovi přesný obraz o self-efficacy učitele. Je to proto, že jeho činnost ovlivňují i další faktory, přičemž mnohé z nich nemůže sám ovlivňovat. Řečeno metodologickou řečí, učitelovo self-efficacy, učitelova činnost a jeho učební výsledky jsou proměnnými, které se sice vzájemně ovlivňují, ale nejsou totožné.

Učitelovo self-efficacy můžeme zkoumat pouze na základě vyjádření učitele - na základě toho, co sám o sobě řekne nebo vyjádří. Možná, že v budoucnu bude možné vniknout do učitelovy hlavy a přesně zkoumat jeho myšlení a uvažování (já osobně se na tuto situaci netěším), ale v současnosti se můžeme spoléhat pouze na jeho osobní vyjádření o tom, co si o sobě myslí a jak o sobě uvažuje.

Kvantitativní výzkum používá při zkoumání self-efficacy sebehodnotící škály. Učitel dostane dotazník, ve kterém je řada výroků a stupnice, na níž uvede stupeň ztotožnění se s daným výrokem nebo vyjádří sílu svého přesvědčení. Takový dotazník je velmi efektivním výzkumným nástrojem, učitel ho umí rychle vyplnit a výzkumník rychle vyhodnotit. Tímto způsobem se zjištujue nejen self-efficacy, ale i mnohé další psychologické konstrukty, jako jsou postoje, zájmy, hodnoty, sebepojetí nebo sebeoceňování člověka.

Slabinou dotazníku je, že učiteli předkládáme výroky, které jsou dekontextualizované. Jsou vytržené ze situací, ve kterých jejich učitel koná, jsou to jen holé popisy. Každá situace má ovšem své širší kontexty, spolupůsobící síly - a ty položky dotazníku self-efficacy nedokážou vyjádřit. Proto dotazníkové výsledky výzkumů self-efficacy musíme interpretovat s tímto omezením. Další problém, se kterým musíme počítat, není na straně dotazníku, ale učitele-respondenta. Učitel, který vyplňuje dotazník, pocit’uje v malé či vyšší míře, že je hodnocen, že odpovědi poskytují jeho sebeobraz, a proto může mít tendenci poskytnout žádoucí odpovědi. Zkresluje, aby byl jeho obraz lepší, hodnotnější. Respondenti se liší v tom, do jaké míry jsou náchylní posky tovat žádoucí a ne autentické odpovědi. Výzkumník tuto tendenci může ovlivnit důkladným vysvětlením výzkumného záměru a zdůrazněním 
(ale i dodržením) anonymity respondenta a jeho dat. Druhý zdrojem problémů na straně respondenta může být jeho schopnost introspekce. Ta se u lidí liší. Pokud je úroveň introspekce vysoká, odpovědi jsou značně validní a poskytují realistický obraz o respondentovi. Pokud je úroveň nízká, respondent neumí přesně „číst“ své myšlení a odpovídá zkresleně.

\subsection{2 \\ Klíčové postavení teorie}

Obecně se kvantitativní přístup považuje za takový výzkum, jehož doménou je sběr a zpracování dat kvantitativním způsobem. Tuto kvantitativnost můžeme nacházet ve více aspektech. Je to počet zkoumaných subjektů, počet dat získaných od každého z nich a počet proměnných, které se naplňují zjištěnými daty. Ideálem kvantitativního výzkumu je, aby se zjištěné údaje daly spolehlivě zobecňovat na celou populaci učitelů. $\mathrm{K}$ tomu je vysoký počet subjektů důležitou, ale ne dostačující, podmínkou. Důležitý je i způsob a kritérium vybírání subjektů tak, aby se zajistila reprezentativnost.

Kvantitativní výzkum self-efficacy zkoumal tuto lidskou charakteristiku na relativně malých souborech (např. 100-150 učitelů), ale existují i rozsáhlé výzkumy řízené organizacemi jako je např. OECD. Ve výzkumu TALIS 2007 bylo zkoumáno 44701 učitelů z 2648 škol ze 14 zemí. Velké soubory byly použity při výzkumu 15letých žáků v rámci PISA 2018. Zúčastnili se ho žáci 79 zemí, přičemž z každé země se zkoumalo 4000 až 8000 žáků. $V$ obou těchto rozsáhlých výzkumech bylo zkoumáno několik charakteristik učitelů a žáků, včetně self-efficacy.

Důležitou vlastností kvantitativního výzkumu není jen numerickost - měření lidské charakteristiky na škále a snaha získat údaje od velkého počtu subjektů. Takový pohled na kvantitativní výzkum je zjednodušující, a proto nepřesný. Důležitou vlastností kvantitativního výzkumu je postavení vědecké teorie jako východiska. Kvantitativní výzkum čerpá z dané teorie, tedy z dosavadních zjištění, a tuto teorii upřesňuje, rozšiřuje a prohlubuje (to je v přímém protikladu s kvalitativním výzkumem, který naopak nesmí vycházet z existující teorie, ale tuto teorii vytvárí.) Bez takové teorie nelze stanovit hypotézy výzkumu, ani produktivní výzkumné otázky - otázky, které posouvají vědeckou teorii dále. Kvantitativní výzkum pracuje kumulativně - sice vychází z dané teorie, ale postupně a neustále získává nové poznatky a integruje je do ní. 


\section{1 .3 \\ Interpretace teorie}

Self-efficacy má dobře rozpracovanou teorii, která prošla a stále prochází zkouškou empirických výzkumů. Jsou jasně vymezeny její prvky, dimenze a determinanty (Bandura, 1997, Pajares, 1996; 2007; Tschannen-Moran, \& Hoy, 2001 - více o tom kapitola 2 J. Mareše). Výzkumy self-efficacy učitele se realizovali u učitelů s různou kvalifikací, délkou praxe, na všech stupních školy a v různých vyučovacích předmětech. Výsledky se dávaly do vztahu k demografickým, osobnostním a profesním charakteristikám. Tak se teorie o self-efficacy rozvíjí, prohlubuje, zpřesňuje a zdokonaluje.

Když se výzkumník rozhodne, že bude zkoumat self-efficacy učitele pro danou oblast (řekněme pro adaptaci dětí do prostředí mateřské školy), musí se rozhodnout, jak bude tuto vlastnost u daných subjektů zkoumat. Předpokládejme, že si zvolí nejčastěji užívaný výzkumný nástroj zkoumání self-efficacy, tj. škálový dotazník. Potom začne uvažovat, jak koncept self-efficacy do svého dotazníku převtělí, jak specificky ho zaměří, jaké složky tento výzkumný nástroj bude mít a jak se obsahově naplní. Základem úvah výzkumníka je, jak má teorii o self-efficacy interpretovat, kterou složku, aspekt, dimenzi zdůrazní a v jakém vztahu bude složky chápat. Jeho rozhodnutí je strategické, protože ovlivní sběr dat a následně jejich interpretaci.

Velkým metodologickým problémem je, že self-efficacy není izolovanou vlastností člověka. Naopak úzce souvisí s dalšími jeho vlastnostmi jako je sebeoceňování, sebekontrola, nebo lokalizace rozhodujícího vlivu (locus of control, Rotter, 1996). Projevuje se to pozitivními a statisticky významnými korelacemi s těmito vlastnostmi učitele. Např́íklad jeden z nejrozšířenějších dotazníků pro zjišt’ování učitelova přesvědčení o osobní zdatnosti TES (Teacher Efficacy Scale) Gibsona a Demba (1984) koreloval s dotazníkem lokalizace rozhodujícího vlivu učitele 0,47, se sebepojetím učitele 0,54 a s odpovědností učitele za učební výsledky žáků 0,57 (podle Tschannen-Moranové, \& Woolfolk Hoyové, 2001). Vzhledem k tomu, že jde psychologické konstrukty, jsou to poměrně vysoké korelace. Proto tito autoři označili self-efficacy učitele za eluzivní, těžko uchopitelný koncept (Tschannen-Moran, \& Woolfolk Hoy, 2001).

Blízkost (i když ne totožnost) self-efficacy a uvedených konceptů někdy svádí výzkumníka ke kontaminaci, resp. ke splynutí různých konceptů v jednom výzkumném nástroji. Dobře to ilustruje zmíněný nástroj TES Gibsona a Demba (1984). Vybrali jsme ho jako př́́klad, protože dlouho sloužil jako ikonický nástroj pro zkoumání self-efficacy učitele a byl použit v mnoha výzkumech v různých zemích světa (Riggs, \& Enoch, 1990; Deemer, \& Minke, 1999; Brouwers, \& Tomic, 2003; Denzine, Cooney, \& McKenzie, 2005). Českou verzi TES validoval Greger (2011) s učiteli gymnázií, 
slovenskou verzi validoval se studenty učitelství i s učiteli z praxe Gavora (2009; 2011).

Autoři TES využili dva klíčové koncepty Bandurovy teorie o self-efficacy. Prvním je přesvědčení o vlastních schopnostech vykonávat určitou činnost (perceived seIf-efficacy). Je to odpověd' na otázky: Jsem schopen to udělat? Vím, jak mobilizovat úsilí a soustředit síly na provedení dané činnosti? Druhým konceptem je představa subjektu o výsledku (outcome expectancy). Je to přesvědčení člověka, že jeho jednání povede k zamýšleným výsledkům. Je to odpověd' na otázky: Co způsobí mé jednání (za předpokladu, že ho umím provádět)? Jaký bude mít dopad? Představa o výsledku tedy má dvě fáze: prvním je předpoklad, že něco umím uskutečňovat a druhým to, že když to uskutečním, k jakým výsledkům se dopracuji.

Gibson a Dembo přijali první Bandurův koncept věrně, ale nazvali ho personal teaching efficacy (PTE), druhý interpretovali jako přesvědčení o schopnosti učitele překonávat nepříznivé vnější vlivy vztahující se k vyučování (vlivy rodinného prostředí, nedostatky ve schopnostech a motivaci žáka apod). Nazvali ho general teaching efficacy (GTE). Příklad položek:

- PTE: „Když se žák zlepšil v učení, je to proto, že jsem našel způsob, jak k němu přistupovat.“

- GTE: „Nemám mnoho možností ovlivnit učedníkovo prospívání, protože hlavní roli při motivaci učit se hraje jeho rodinné prostředí.“

Ve více výzkumech s použitím TES se ukázala nejednoznačnost faktorové struktury použitých dotazníků, což zpochybnilo jejich konstruktovou validitu. Týkalo se to zejména chování faktoru GTE, který nejvíce trpěl tím, že v něm splynul koncept lokalizace rozhodujícího vlivu a Bandurův koncept outcome expectancy. Vlivem toho v některých situacích dotazník produkuje obtížně interpretovatelná data.

V protikladu s navrženým složením dotazníku TES generovala v některých studiích faktorová analýza pouze jeden faktor (např. Deemer, \& Minke, 1999), nebo tři faktory (např. Denzine, Cooney, \& McKenzie, 2005), nebo dokonce čtyři faktory (např. Brouwers, \& Tomic, 2003). Někteří autoři interpretovali faktory způsobem odlišným od Gibsona a Demba. To platí zejména pro faktor GTE, který trpí teoretickou nekonzistentností a v některých situacích přinesl kolísavé údaje.

Někteří autoři (Guskey, \& Passaro, 1994; Deemer, \& Minke, 1999; Brouwers, \& Tomic, 2003) poukazují na to, že problém s GTE spočívá taky ve znění jeho položek. Zjistili, že položky v PTE jsou formulovány v první osobě (např. Když žák dostane lepší známky, je to obvykle proto, že jsem našel lepší zpưsoby jeho výuky), zatímco položky v GTE odkazují na třetí osobu (např. Učitel je velmi omezen, čeho může dosáhnout, protože motivaci žáka utváří domácí prostředí). Dále autoři poznamenali, že většina položek v GTE je formulována negativně (Mé působení na 
žáka má malý vliv na studenty ve srovnání s vlivem domácího prostredí), zatímco položky v GTE jsou většinou formulovány pozitivně (Když se žákovi daří lépe než obvykle, často je to proto, že vynakládám velké úsilí). Jedná se o důležité námitky proti konceptualizaci dotazníku TES.

Příklad s dotazníkem TES tedy ilustroval dvě problémová místa při konstrukci dotazníků zjištujících self-efficacy učitele. První je interpretace Bandurových konceptů, které leží v základu jeho teorie, druhé spočívá v aplikaci těchto konceptů při formulaci položek pro tyto koncepty. Posuny v interpretacích přináší odlišné výsledky a - jak jsme ukázali - i metodologické problémy.

\subsection{4}

\section{Induktivní a deduktivní strategie při konstrukci dotazníků}

Obecně se uvádí, že kvantitativní výzkum je založen na deduktivním postupu. Směřuje od obecného, tedy od teorie ke konkrétnímu, tedy k datům získaných v terénu. Je to postup shora dolů. 0 induktivním postupu se obecně uvádí, že je charakteristický pro kvalitativní výzkum. Výzkumník sbírá data v terénu a na jejich základě formuluje závěry. Je to postup zdola nahoru. I když jsou tyto teze o odlišných strategiích kvantitativního a kvalitativního výzkumu v zásadě správné, reálná praxe výzkumníka ukazuje rozdíly. Typicky se to stává při tvorbě položek do dotazníku. V kvantitativním výzkumu se při tvorbě položek dotazníku může výzkumník rozhodnout pro oba postupy, deduktivní nebo induktivní. Uvedeme dva príklady.

Induktivní strategií vznikaly položky dotazníku OSTES (The Ohio State Teacher Efficacy Scale; Tschannen-Moran, \& Woolfolk Hoy, 2001). Dotazník měří self-efficacy učitele vyučovat ve tř́́dě. Nástroj vznikal postupně v cyklických krocích. V první etapě autorky zorganizovaly seminář, kterého se účastnili výzkumníci, studenti doktorského studia a učitelé z praxe. Každý účastník navrhl 8-10 nových položek. Takto vzniklo asi 100 návrhů, které se však zčásti překrývaly. Pak skupina analyzovala všechny návrhy a konsensem vybrala ty, které podle nich nejlépe vyjadřují důležité prvky self-efficacy v práci učitele ve třídě. Do užšího výběru se dostalo 52 položek Př́klady:

- Co můžete udělat, abyste motivovali žáky, jichž nezajímá učení se ve škole?

- Co můžete udělat, aby rodiče pomáhali svým dětem při učení se?

Tento nástroj byl testován $v$ terénu ve třech výzkumech s učiteli a studenty učitelství. Ověřovalo se, jak jeho položky zapadají do celkové koncepční struktury nástroje a to pomocí faktorové analýzy. Byly extrahované tři faktory, které byly 
pojmenovány takto:

- Zdatnost motivovat žáky (efficacy for student engagement)

- Zdatnost používat vyučovací postupy (efficacy for instructional strategies)

- Zdatnost řídit třídu (efficacy for classroom management).

Po finálním ověřování s 366 učiteli a studenty učitelství bylo v dotazníku ponecháno 24 nejlepších položek. Autoři se po faktorové analýze rozhodli pro dvě řešení: jednak pro tři uvedené faktory, jednak pro alternativu pouze s jedním faktorem. Tř́faktorové řešení vyšlo při souboru učitelů, jednofaktorové při vzorku studentů. Když oba podsoubory sloučily, faktorová analýza ukázala na jeden faktor. Autoři přesto vyčíslují výsledky oběma způsoby - průměr za celý dotazník a průměry $\mathrm{v}$ jednotlivých faktorech.

Shrneme, že položky dotazníku OSTES vznikaly induktivním způsobem a jejich použití vedlo ke vzniku alternativních teorií o složkách self-efficacy učitele pro vyučování, které byly generovány faktorovou analýzou.

Deduktivní strategie postupuje při konstrukci dotazníku naopak. Autoři před konstrukcí dotazníku mají poměrně přesnou představu o jeho složkách, kterou vytvořili na základě studia literatury z dané problematiky. Po vymezení a definování těchto složek navrhnou pro ně potenciální položky. Po zadání dotazníku respondentům potom pomocí faktorové analýzy oveří, jak tyto složky obstály v terénu. Tedy, zda se všechny uvažované složky uplatnily a do jaké míry se naplnily položkami. Ukáže se také, v jakém vzájemném vztahu jsou navrhované složky (výpočtem korelací).

Deduktivní strategii ilustrujeme na výzkumu konstrukce dotazníku Zdatnost učitele spolupracovat s rodiči (Majerčíková, \& Gavora, 2013). Autoři vyšli z typologie angažování rodičů do práce školy od Epsteinové (Epstein, \& Salinas, 2004) a Bully (1989). Na jejich základě vytvořili banku 65 položek pokrývajících předpokládané oblasti spolupráce škola - rodina.

Př́klady znění položek:

Vyjádřete, jak odhadujete své schopnosti:

- využívat všechny dostupné možnosti,jak rodiče informovat o prospívání jeho dítěte ve škole,

- rodičům navrhnout způsoby řešení výchovných problémů dítěte,

- rodičům vysvětlit, jak funguje rada školy.

Smysluplnost a srozumitelnost položek posoudily tři učitelky s různou délkou praxe. Osm položek kvalifikovaly jako nevhodné, a proto byly z banky položek vyloučeny. $V$ této podobě měl dotazník 57 položek. Tyto byly podrobeny faktorové analýze. V rámci ní vypadly položky, které měly nízkou faktorovou zátěž, byly redundantní 
nebo ukazovaly neinterpretovatelné zařazení. Výsledná podoba dotazníku má 24 položek. Faktorová analýza potvrdila 5 složek dotazníku, které byly v souladu s teorií, na jejímž základě vznikly. Byly to složky 1) Schopnost radit rodičům ve věcech výchovy v rodině, 2) Schopnost přesvědčovat rodiče, aby podpořili školu, 3) Schopnost informovat o prospívání dítěte, 4) Schopnost vysvětlit fungování školy jako organizace, 5) Schopnost být transparentní vůči rodičům.

Shrneme, že deduktivní strategie při tvorbě položek vychází z konkrétní teorie o složkách self-efficacy, na jejímž základě se formulují položky, a poté se s daty z terénu ověřuje existence těchto složek a jejich vzájemný vztah.

\subsection{5}

\section{Forma položek v dotazníku}

Dotazníky self-efficacy používají běžně škálové položky a respondent uvede svou volbu na jedné z nabízených stupňů škály. Typy škál jsou rozličné. Likertova škála žádá uvést míru souhlasu s daným výrokem. Příklad:

Když žák podal lepší výkon než obvykle, často je to díky mému zvýšenému úsilí. Vưbec nesouhlasím - naprosto souhlasím

Jiný typ škály zjišt'uje míru možností učitele:

Co jste schopný/á udělat s velmi problémovými žáky? Vůbec nic - velmi mnoho

Ve výzkumu se někdy používají místo tradičních škál popisy modelových situací (vignetts). Př́íklad:

Někteři žáci ve třídě se neustále baví, posílají si papírky a ignorují vyučování. Jejich výkon v učení je dobrý, někdy dokonce výborný. Jejich chování je však provokativní a narušuje vyučování. Do jaké míry byste uměli eliminovat takové chování?

Učitel hodnotí své možnosti řešení dané situace na škále od „zcela“ po „vůbec ne“. (Ashton, Buhr, \& Crocker, 1984, cit. dle Tschannen-Moran \& Woolfolk Hoy, 2001)

Konstruktér výzkumného nástroje musí zvážit jemnost hodnocení, kterou nastaví počtem poloh na stupnici. Bandura (2006) doporučuje spíše vícepolohové škály než tradiční pětibodové nebo sedmibodové, nebot' ty jsou jemnější. Ve své příručce Bandura (2006) nabízí 100 bodové škály od 0 po 100, s desetibodovými intervaly: Učitel hodnotí své možnosti řešení dané situace na škále od „zcela“ po „vůbec ne“.

Ohodnot'te míru svého presvědčení číslem od 0 do 100:

Vyjadřovat svobodně názory na důležité záležitosti školy (nízké přesvědčení - vysoké přesvědčení). 
Bandura také doporučil, že kořen škály musí být výraz I can ... (jsem schopen, umím to udělat), ne I will ... (udělám to). První výraz poukazuje na potencialitu, druhý na záměr. Vnímaná zdatnost je silným determinantem záměru, ale oba pojmy jsou koncepčně odlišné. Bandura dále požaduje dobře vymezit oblast, které se vnímána zdatnost týká. Pokud je toto vymezení nedostatečné, hrubé, výzkum vyprodukuje falešné údaje. Jiným pravidlem tvorby nástroje je to, že položka popisuje určitou činnost, na jejíž provedení musí učitel vyvinout určitou námahu, úsilí. Respondent se vyjadřuje, do jaké míry je schopen toto úsilí vyvinout. Tato míra se vyjadřuje na škále.

Bandura své zásady promítl do návrhu svého dotazníku Teacher Self-Efficacy Scale (Bandura, 2006, s. 328), který obsahuje 28 škál rozložených do šesti složek. Uvádíme názvy složek a př́íklad znění položky. Každá položka má škálu sahající od nuly po 100. Učitel na ní hodnotí své přesvědčení, že danou činnost umí uskutečnit.

\section{Schopnost ovlivňovat rozhodovací procesy ve škole:}

Vyjadřovat svobodně názory na důležité záležitosti školy.

\section{Vyučovací zdatnost:}

Srozumitelně vysvětlit učivo i slabším žákům.

\section{Schopnost řešit disciplinární otázky:}

Poradit si se zlobícími žáky.

\section{Angažování rodičů:}

Radit rodičům při domácím učení se žáků.

\section{Angažování členů komunity:}

Zapojení firem do práce školy.

\section{Schopnost vytvářet pozitivní školní klima:}

Vzbuzovat důvěru žáků v učitele.

Autor neuvádí psychometrické údaje (validitu a reliabilitu) svého dotazníku, podle kterých bychom mohli posoudit jeho metodologickou kvalitu. Dotazník se použil v několika výzkumech, široké uplatnění však neměl.

Kvantitativní výzkum má rozvinutou metodologii a výzkumníci mají k dispozici výzkumné nástroje, které jsou zaměřeny na zkoumání self-efficacy u učitelů s různými demografickými charakteristikami a akademickým zaměřením. Výzkumníci musí neustále řešit problémy s validitou těchto nástrojů, aby produkovali, pokud možno jednoznačné výsledky. Není to proto, že by metodologie a statistika neměly v rukou vhodné prostředky, nebo že je výzkumníci neumí použít ale proto, že koncept self-efficacy je eluzivní a umožňuje širší interpretaci, která se pak promítá do konstrukce daného výzkumného nástroje a následně do dat, která výzkumník sesbíral v terénu. Tuto situaci ovšem nehodnotíme kriticky. Problémy, kterým 
musí výzkumníci čelit, je vedou k hlubšímu uvažovaní, dalšímu ověřování svých výzkumných nástrojů a k lepším datům.

\section{2 \\ Kvalitativní a smíšené přístupy ve výzkumech self efficacy}

Nepřehlédnutelným trendem mnohých současných výzkumů v sociálních vědách (jak již bylo zmíněno) je „odklon“ od kvantitativní metodologie a naopak větší zužitkování metod na bázi kvalitativních šetření, případně aplikace tzv. smíšeného výzkumu, kde jsou zastoupeny oba dva hlavní badatelské směry.

Předmět výzkumného zájmu kvalitativních šetření nacházíme v lidském jedinci, s jeho jedinečnými psychosociálními vlastnostmi, kterýžije v určitém společenství a k němuž je vázán mnoha okolnostmi. Výzkumníka zajímají vztahy a postoje ke zkoumanému tématu a způsob, jakým téma interpretuje, v jakých souvislostech, v jakých podmínkách a v jakém časovém pohledu (nyní - příště - v budoucnu). Plyne z toho, že při kvalitativním výzkumu se neredukuje počet proměnných ani vztahy mezi nimi, o jejich redukci rozhodují samy zkoumané subjekty. V popředí jsou otevřené výzkumné plány, jejichž realizací se má dospět $\mathrm{k}$ analýze velkého množství informací od relativně malého počtu jedinců. Je podstatné, že témata vycházejí z reálného prostředí respondentů a jsou něčím, čím respondenti „žijí“ a co je ovlivňuje. Významně se individuální charakteristiky vynořují při vzájemné interakci mezi aktéry šetření, což vede k poznávání individuálních „příběhů“ člověka a jeho subjektivní prezentaci. Jinak řečeno: kvalitativní šetření mají velmi často narativní a etnografický charakter. $\mathrm{Z}$ nadhledu můžeme hovořit o tom, že cílem kvalitativní metodologie je vytvořit holistický obraz o zkoumaném jevu a popis toho, jak účastníci šetření jevy a vztahy interpretují a zdůvodňují.

o jaké konkrétní postupy se kvalitativní výzkumy opírají? Výzkumné procedury kvalitativních šetření se liší mírou aktivity badatele i různou interakcí s prostředím, ve kterém výzkum probíhá. Pokrývá spektrum od „pohodové“ analýzy dokumentů, přes terénní výzkum, případové studie (tzv. Single case výzkum, in Ježek a kol. 2006), až po náročné kvalitativní experimenty (obr. 7).

Inventář konkrétních metod kvalitativního výzkumu se opírá o dvě základní skupiny: pozorování (observace skrytá nebo zjevná) a dialogické postupy. $\mathrm{Z}$ dialogických metod se obvykle vyčleňuje polostrukturovaný nebo nestrukturovaný rozhovor (variantou je tzv. narativní dialog, kde se dotazovaný podněcuje k vyprávění „svého“ příběhu). Ve skupinovém dialogu se komunikace uskutečňuje obvykle s více než třemi osobami najednou a vychází se z obvyklé dyády: otázka odpověd'. Mnohem méně je sledována vzájemná interakce mezi účastníky dialogu. 


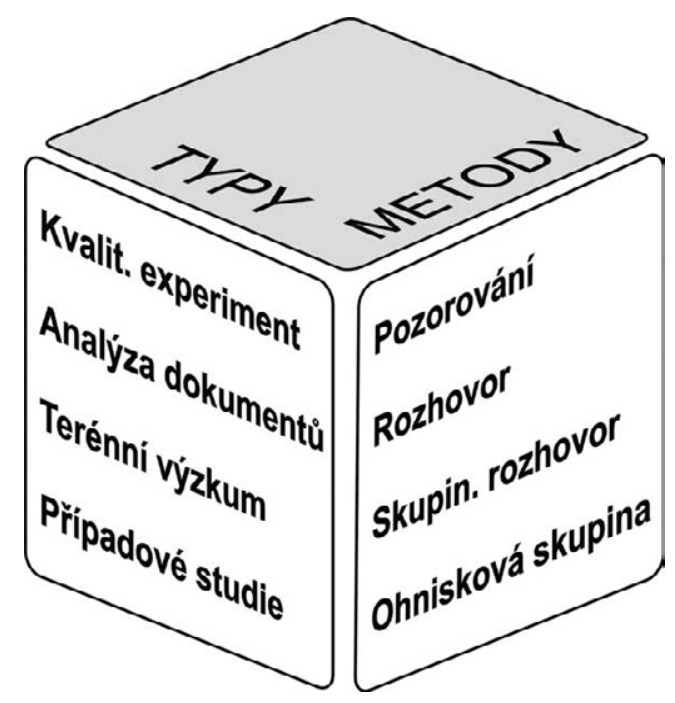

Obr. 7: Typy kvalitativních šetření a konkrétních metod

Osobitou pozici ve výčtu kvalitativních metod má tzv. ohnisková skupina (nebo též interview v ohniskové skupině = focus group). Jedná se o výzkumnou situaci, ve které výzkumník (v roli moderátora) určuje zaměření diskuse a jejím ohniskem je předem zvolené a etablované téma. Zájmem je sledovat proměny „ohniskového“ tématu v závislosti na skupinové interakci. (Volně podle Gavory 2006, Ježka et al. 2006 a Pelikána 1998). V dalším představíme uspořádané klíčové poznatky o této metodě a poté popíšeme její konkrétní užití při výzkumu self-efficacy mezi začínajícími vysokoškoláky.

\subsection{1}

\section{Charakteristika interview v ohniskové skupině - focus group}

O její podstatě, výzkumném dosahu, vnitřních fázích a dalších charakteristikách uvažují mnozí autoři a v mnohém se shodují. Jednoznačná shoda panuje v názoru, že jde o výzkumný nástroj na komunikační bázi. Nielsen (1997) se o ohniskových skupinách vyjadřuje jako o poněkud neformální technice zkoumání, jejímž prostřednictvím lze získat názory členů skupiny na určitou diskutovanou problematiku. Připomíná, že je třeba využít (audiovizuální) techniky k záznamu interakce, aby hodnocení a analýza dění ve focus group mohla probíhat časově nezávisle na reálném dění ve skupině. Autor dále uvádí, že dialog v ohniskové skupině často 
odhalí spontánní reakce a myšlenky jednotlivých členů skupiny, umožní sledovat skupinovou dynamiku a mnohdy odkryje nepředvídatelné problémy a vztahy.

Podobně Morgan (2001) o focus group hovoří jako o skupinovém rozhovoru a dodává, že více než o klasický dialog ve smyslu výměny otázek badatele a odpovědí respondenta se jedná o interakci uvnitř respondentské skupiny. Diskuse nad tématy je zásadně ovlivněna specifickou rolí moderátora. Charakteristickým znakem ohniskových skupin je explicitní užívání skupinové interakce k získání údajů, názorů a pohledů, které by byly bez interakce ve skupině těžko přístupné.

Také Gavora (2006) řadí ohniskovou skupinu (přesněji interview s ohniskovou skupinou) mezi dialogické výzkumné postupy. Záměrem je ve skupinové interakci diskutovat na jedno společné téma a sledovat zapojení a aktivitu jednotlivých členů skupiny. Obvykle se jedná o skupinu 5 - 10 členů, kterou lze považovat za homogenní. Urychlující (i regulující) funkci obvykle má moderátor: získává respondenty k dialogu, klade téměr zcela otevřené otázky a posouvá téma potřebným směrem. Vzniklá dynamická interakce (synergický skupinový efekt) přináší vícesměrný dialog, který s postupujícím časem, vzájemným seznamováním a zvýšenou otevřeností může přejít do „auto-dialogického“ stádia, kdy role a iniciace moderátora ustupují do pozadí a téma je komentováno samotnými respondenty.

Nejde o to, aby se diskutující dohodli na společném přístupu k tématu, cílem je naopak zachovat si individuální vidění, interpretovat své názory a postoje před ostatními i umět je zdůvodnit. Jednotliví členové ohniskové skupiny „generují verbální data“, jejichž výzkumná využitelnost je závislá na způsobu jejich uchování pro pozdější výzkumné zpracování. Proto se jeví jako téměř nezbytné zaznamenat skupinové dění na auditivní nebo audiovizuální médium, což vytvoří časově nezávislou možnost dalších analýz.

\section{Moderátor a jeho role}

Klíčovou osobou v ohniskové skupině je moderátor, který celou diskusi iniciuje a průběžně směruje (řídí). Nejčastěji jím bývá školený psycholog, znalý psychologie verbálního a neverbálního sdělování. Pokládá respondentům otázky (většinou otevřeného typu), používá projektivní otázky k testování názorů, parafrázování a jiné psychologické metody. Jeho hlavní snahou je zjistit různé individuální postoje $\mathrm{k}$ dané problematice a nejdůležitější aspekty, které tyto postoje ovlivňují.

Obecněji se očekává, že moderátor prokáže svou profesionalitu a metodologickou zběhlost $v$ přípravě, $v$ reálném dialogu s respondenty i ve fázi analýzy získaných dat a jejich interpretaci. Nutné dovednosti (komunikativní a interakční, schopnost definovat pravidla, klást klíčové otázky, nalézat podstatné myšlenky a citlivě je rozvíjet, schopnost nonverbálního porozumění, dovednost měnit interakční styl a stimulaci v závislosti na měnících se situacích atd.) oprávněně ukazují, 
že kvalitně „moderovat“ nemůže každý výzkumník nebo sebevíce zaujatý laik. Hovoříme-li o roli „dobrého moderátora“, nemůžeme opomenout téma "typologie respondentů“. Jde o jeho připravenost na skutečnost, že ve skupině budou individuálně různí lidé, lišící se nejen postoji a názory, ale také rolovým jednáním, patrným v průběhu interakce.

\section{Participanti a jejich typologie}

Vybraní respondenti obvykle splňují určité podmínky a kritéria. Zkušenosti ukazují, že se ve skupinové interakci objeví participanti - účastníci, které je možné zařadit do následující „typologie“ (Morgan 1997):

- aktivní účastník, kterýje motivován a má zájem poskytovat moderátorovi potřebné informace;

- stydlivý či introvertní jedinec, který má potíže s komunikací a jemuž je třeba věnovat větší pozornost a povzbuzovat jej $k$ diskusi;

- jedinec, „který vše ví a všemu rozumi”, a má proto velmi často tendenci skupině dominovat; je třeba jej mírnit, aby zcela neznechutil ostatní;

- „nezadržitelný mluvči” - jde o jedince, který sice adekvátně odpovídá na položené otázky, ale tato odpověd' jej většinou neuspokojuje, a proto pokračuje dále svým typickým „chtěl jsem vlastně ř́ci..." nebo „podle mého soudu je, ale...";

- nejkomplikovanější je spolupráce s jedincem, kterého bychom mohli označit jako kverulanta. Tento typ respondenta ve skutečnosti nechce participovat na tématu diskuse, ale pokouší se komplikovat situaci moderátorovi sarkastickými poznámkami či nevhodnými komentáři.

Profesionalita a metodologická připravenost moderátora se právě projeví při moderování ohniskové skupiny, ve které se objeví nejrůznější „typy“ participantů. Jeho iniciace musí být adresné a odpovídající individuálním projevům jednotlivých zpovídaných osob.

\section{Ohnisková skupina a její fáze}

Mnohem méně je známo to, jak badatelé pracují $\mathrm{v}$ ohniskové skupině $\mathrm{s}$ jejími účastníky v jednotlivých etapách či fázích. Opodstatněně se ukazuje, že klíčové pro zvládnutí role moderující osoby je př́ípravné stádium (Krueger, 1998) což poukazuje na zásadní vliv připravených otázek na pozdější kvalitu průběhu skupinové diskuse. Podle očekávání preferuje moderátor otázky otevřené a stimulující, neosobní a nezaujaté.

Také okamžik prvního setkání moderátora a členů skupiny je významný. Sebelepší př́íprava se ne zcela zúročí, nedojde-li k navázání prvního pozitivního kontaktu. Problémy mohou být formální (nevhodný počet participantů nebo jejich 
výběr), zásadnější pak v tom, že moderátor dostatečně nevysvětlil „pravidla“ a neobjasnil „ohniskové téma“, nebo že zaujal jinou než stimulující strategii. Příklad obecněji formulovaných pravidel:

- Žádná odpověd' není śpatná nebo dobrá, odpovědi jsou pouze pravdivé a otevřené nebo naopak. (Moderátor se musí snažit vytvořit pozitivní, uvolněnou atmosféru tak, aby se respondenti neostýchali hovořit o daném tématu spontánně).

- Cílem diskuse není jen s někým souhlasit nebo naopak nesouhlasit. Každý reprezentuje sám sebe a to i v př́padech, když se projeví převažující skupinový názor.

- Diskuse se sice pro potřeby následující analýzy zaznamenává (audio nebo videozáznam). Jde však o technický krok, který není významný pro respondentské reakce nebo hodnocení osobního podílu na interakci.

- Každý dostane stejný prostor pro výpovědi, osobní názor..., ale neměl by očekávat od moderátora hodnocení nebo podobnou zaujatou reakci atd.

Odkazujeme na: Larson, K., N. Grudens-Schuck, and B. Lundy Allen, 2004. Can You Call It a Focus Group? Ames, Iowa: Iowa State University Extension. http://www. extension.iastate.edu/Publications/PM1969A.pdf a další podobné texty (např. http://www.gmi-mr.com/net-mr/data-collection-software.php), v nichž se můžeme blíže seznámit s dalšími pravidly pro účastníky focus group.

0 velkém vlivu začátku komunikace na její další průběh píší mnozí autoři. Garson (http://faculty.chass.ncsu.edu/garson/PA765/index.shtml) hovoří doslova o „lámání ledu“, obrazně popisujícím stav v počátcích konverzace. Samotná interakce by měla být přiměřeně dlouhá ( 1 až 2 hodiny) a je ovlivněna mnoha faktory (věkem respondentů, tématem a očekávanou hloubkou uvažování, psychohygienickými podmínkami atd.). Interakce by měla vycházet ze dvou hlavních prolínajících se linií: první - dané ohniskovým tématem a druhou - vyvěrající z respondentských reakcí a celkového kontextu. Dick (1998) doporučuje, aby první kontakt (po zahájení a objasnění záměrů setkání) měl podobu diskuse v kruhu, kdy se v rychlém sledu představí všichni respondenti a zaujmou stanovisko k nějaké triviální otázce či tématu (hovoří o sociálním sžívání).

Připomeneme myšlenky Krugera (http://www.tc.umn.edu/ rkrueger/index. html), který radí moderátorům, aby v průběhu interview hledali „velké myšlenky“ a na jejich základě iniciovali a vedli dialog potřebným směrem. Vše s citem pro nestranný pohled a s vyvarováním se verbálním soudům, že právě tato výpověd’ byla výborná a že jsme ji očekávali. Obdobně nevhodně může působit použití vizuálních pomůcek (flip chart), s jejichž pomocí moderátor zapisuje myšlenky a jen některé graficky označuje jako hlavní - výborné - stěžejní. 
Je zajímavé, že autoři popisující proceduru focus group se nějak významněji nerozepisují o tom, jak by měla být diskuse $\mathrm{v}$ ohniskové skupině zakončena. Nicméně z kontextu vyplývá, že moderátor by měl připomenout vývoj tématu a nalezení zásadních poznatků, aniž by je hodnotil, strukturoval nebo uvažoval o jejich větším či menším významu.

\section{Lokace interview v ohniskové skupině}

Místem interview $\mathrm{v}$ ohniskové skupině by měla být prostorná místnost s dostatkem světla, respektující základní psychohygienické požadavky tak, aby se participanti cítili dobře a uvolněně. Jejich usazení ke kulatému nebo oválnému stolu se jeví jako nejvýhodnější, aby žádný z nich nezastával dominantní pozici. Z celé diskuse je většinou pořizován audio nebo videozáznam, o kterém jsou participanti předem informováni. Za nadstandardní považujeme požadavek, aby místnost, ve které se ohniskové skupiny konají, byla vybavena jednocestným zrcadlem, za kterým by mohl výzkumný tým sledovat celou diskuzi, formulovat hypotézy, pořizovat si poznámky a sledovat chování jednotlivých aktérů.

\section{Technické podmínky focus group}

Interview v ohniskové skupině mají nepředvídatelný průběh a interakce jejích členů jsou v mnoha případech bohaté na nejrůznější proměny komunikačního obsahu. Není v lidských silách „on-line“ přijímat tyto informace a ještě je dále zpracovávat. Jediným řešením je záznam dění v ohniskové skupině a poté jeho analýza. Využívá se především audiovizuální techniky, kdy kamera v nerušící pozici snímá a zaznamenává nonverbální dění ve skupině a mikrofon (nebo jejich skupina) snímá a vede k záznamu hlasovou informaci. Kamera může být bez lidské obsluhy a tzv. „na pevno“, výhodnější je však s obsluhou, která reaguje na bližší projevy participantů (např. mimické projevy) a ty snímá v potřebném detailu.

Obsahově není nezbytné, aby v záběru komunikující skupiny byl i moderátor, dokonce je výhodnější, aby zůstal mimo záběr. Pro toho, kdo záznam sleduje, jsou pak přirozenou vizuální dominantou především účastníci skupinové diskuse.

Jako zajímavost uvedeme jednu alternativu focus group, kterou popisuje Silverman (dostupné na: http://www.mnav.com/onlinetablesort.htm). Zamýšlel se nad rozdíly mezi tím, zda šetření probíhá v klasické ohniskové skupině „tváří v tvář“, nebo se jedná o šetření „po telefonu“. Autor podle očekávání připisuje větší věrohodnost a autenticitu klasickému šetření, pro „mediální variantu“ hovoří rychlost, dostupnost participantů a ekonomičnost. 


\section{Data získaná z focus group a jejich zpracování}

Pojednání o podstatě procedury focus group zakončíme poznámkou o odpovědích na otázku: Co $\mathbf{s}$ daty získanými ze skupinové interakce? Obvykle se dovídáme, že je potřebné ze záznamu přepsat verbální komunikaci mezi účastníky ohniskové skupiny a tu poté dále analyzovat. Hledají se významné myšlenky, tematický kontext a proměny obsahu v závislosti na průběhu interakce. Avšak bližší „návody“, jak naložit s daty, povětšinou chybí.

\begin{tabular}{|l|l|}
\multicolumn{1}{|c|}{ Metoda } & \multicolumn{1}{c|}{ Charakteristika - popis } \\
\hline $\begin{array}{l}\text { Metoda práce } \\
\text { s časovými osami }\end{array}$ & $\begin{array}{l}\text { Z textu jsou vybrány všechny údaje, které } \\
\text { identifikují určité časové jednotky nebo důležité } \\
\text { události. Z nich je sestavena časová osa, do které } \\
\text { se informace zanáší. }\end{array}$ \\
\hline $\begin{array}{l}\text { Metoda vytváření tzv. } \\
\text { trsů }\end{array}$ & $\begin{array}{l}\text { Jedná se o uspořádání dat (výroků) do skupin } \\
\text { na základě jejich podobnosti - překryvu, např. } \\
\text { tematický, časový či prostorový překryv. }\end{array}$ \\
\hline $\begin{array}{l}\text { Metoda zachycení } \\
\text { vzorců }\end{array}$ & $\begin{array}{l}\text { Výzkumník vyhledává a zaznamenává v datech } \\
\text { se opakující vzorce, témata, struktury. }\end{array}$ \\
\hline $\begin{array}{l}\text { Metoda kontrastů } \\
\text { a srovnání }\end{array}$ & $\begin{array}{l}\text { Výzkumník provádí odlišení např. dvou } \\
\text { identifikovaných kategorií a hledá jejich rozdíly } \\
\text { (přestože mají zároveň mnoho společného). }\end{array}$ \\
\hline Metoda faktorování & $\begin{array}{l}\text { Provádí se odhalení faktorů, které nejsou př́mo } \\
\text { pozorovatelné, mají implicitní charakter, ale } \\
\text { ovlivňují určitý jev, situaci apod. }\end{array}$ \\
\hline $\begin{array}{l}\text { Metoda zakotvené } \\
\text { teorie }\end{array}$ & $\begin{array}{l}\text { Dochází k integraci kvalitativních dat získaných } \\
\text { různými metodami a jejich analýzou směřující } \\
\text { k teoretickému poznání. Využívány jsou různé } \\
\text { úrovně kódování a postupně se přechází } \\
\text { z deskriptivní roviny do roviny hledánía nalézání } \\
\text { toho, co je skryto za „prostým popisem“. }\end{array}$ \\
\hline $\begin{array}{l}\text { Metoda narativní } \\
\text { rekonstrukce }\end{array}$ & $\begin{array}{l}\text { Na základě analýzy kvalitativních dat se výzkumník } \\
\text { pokouší rekonstruovat určitý jev v procesu jeho } \\
\text { vývoje. }\end{array}$ \\
\hline
\end{tabular}

Tab. 6.1: Výčet a charakteristika některých metod kvalitativní analýzy dat 
Nicméně v české literatuře (např. Hendl 1997, 2005, Švaříček \& Šed'ová 2007) nacházíme kvalifikovanou odpověd' na otázku, jaké metody lze použít při analýzách dat vzniklých z kvalitativních šetření, a tedy i v př́ípadech výzkumů, na bázi focus group. Jejich přehled uvádíme v tab. č. 6.1, která vznikla volně podle Miovského (2006).

V celkovém pohledu, jak se jeví ze studia dostupné literatury, je tematika „focus group“ poněkud nehomogenní, a to především různým „objemem“ zveřejňovaných poznatků o jejích jed notlivých aspektech. Některé aspekty jsou bibliograficky popsány ve velkém detailu, jiné jsou spíše načrtnuty bez dalšího upřesnění. Charakteristické znaky a jejich vnitřní obsah shrnuje tab. č. 6.2.

Pozn.: charakteristiku metody focus group jsme představili jako sumář poznatků z prací z let 2008, 2010 a 2012.

V kapitole 7.2, na základě zkušeností, představujeme vlastní výzkum, který byl realizován mezi studenty - vysokoškoláky, kteří nastoupili na univerzitu ke svému studiu. 


\begin{tabular}{|c|c|c|c|c|c|c|}
\hline Aspekt & \multicolumn{6}{|c|}{ Procedura focus group } \\
\hline Organizace & \multicolumn{2}{|c|}{$\begin{array}{l}\text { Cíle, aktéři, strategie, } \\
\text { výzkumná forma }\end{array}$} & \multicolumn{2}{|c|}{$\begin{array}{l}\text { Výběr moderátora } \\
\text { a specifikace jeho role }\end{array}$} & \multicolumn{2}{|c|}{$\begin{array}{l}\text { Technické a technologic- } \\
\text { ké podmínky }\end{array}$} \\
\hline $\begin{array}{l}\text { Výzkumná } \\
\text { forma }\end{array}$ & \multicolumn{2}{|c|}{$\begin{array}{l}\text { „Tváří v tvář́“ (autentic- } \\
\text { ká př́má komunikace) }\end{array}$} & \multicolumn{2}{|c|}{$\begin{array}{l}\text { Po telefonu (zpro- } \\
\text { středkovaná auditivní } \\
\text { komunikace) }\end{array}$} & \multicolumn{2}{|c|}{$\begin{array}{l}\text { Videokonference } \\
\text { (zprostředkovaná AV } \\
\text { komunikace) } \\
\end{array}$} \\
\hline Prostředí & \multicolumn{2}{|c|}{$\begin{array}{l}\text { Sociální klima, volba } \\
\text { dne a hodiny }\end{array}$} & \multicolumn{2}{|c|}{$\begin{array}{l}\text { Fyzikální parametry } \\
\text { prostředí (rozmístění...) }\end{array}$} & \multicolumn{2}{|c|}{$\begin{array}{l}\text { Potřeby (jídlo, pití, } \\
\text { přestávky...) }\end{array}$} \\
\hline Průběh & $\begin{array}{l}\text { Příprava } \\
\text { (strategie } \\
\text { a organi- } \\
\text { zace) }\end{array}$ & $\begin{array}{l}\text { Iniciace } \\
\text { („lámání } \\
\text { ledu“, posi- } \\
\text { lování) }\end{array}$ & $\begin{array}{l}\text { Interakce } \\
\text { (otázky, } \\
\text { odpovědi, } \\
\text { synergie) }\end{array}$ & $\begin{array}{l}\text { Vizuali- } \\
\text { zace (flip } \\
\text { chart, pře- } \\
\text { stávky) }\end{array}$ & $\begin{array}{l}\text { Finalita } \\
\text { (fixace } \\
\text { získaných } \\
\text { významů }\end{array}$ & $\begin{array}{l}\text { Analýza } \\
\text { dat (po- } \\
\text { stupy kval. } \\
\text { metodol. }\end{array}$ \\
\hline Téma & \multicolumn{2}{|c|}{$\begin{array}{l}\text { Uzavřené (klíčová slova, } \\
\text { symbolické pojmy a vše } \\
\text { „okolo“) }\end{array}$} & \multicolumn{2}{|c|}{$\begin{array}{l}\text { Polotevřené (žrejmá te- } \\
\text { matická linie bez jasných } \\
\text { limitů) }\end{array}$} & \multicolumn{2}{|c|}{$\begin{array}{l}\text { Otevřené (vývoj postojů } \\
\text { - vztahů, vynořování } \\
\text { významů }\end{array}$} \\
\hline \multirow[t]{2}{*}{ Aktéři } & \multicolumn{2}{|c|}{ Moderátor $(\mathrm{M})$} & \multicolumn{2}{|c|}{ Participanti (RR) } & \multicolumn{2}{|c|}{ Převažující interakce } \\
\hline & \multicolumn{2}{|c|}{$\begin{array}{l}\text { Profesionalita, etika, } \\
\text { metodologická zběhlost, } \\
\text { komunikativní a inte- } \\
\text { rakční dovednosti, nale- } \\
\text { zení velkých myšlenek a } \\
\text { jejich rozvoj, nonverbální } \\
\text { porozumění, nedirektiv- } \\
\text { ní přístup, zpětná vazba, } \\
\text { komunikační taktika } \\
\text { a strategie... }\end{array}$} & \multicolumn{2}{|c|}{$\begin{array}{l}\text { Typ skupiny (smíšená } \\
\text { x homogenní), výběr } \\
\text { a počet, umístění, osob. } \\
\text { charakteristiky, vztah } \\
\text { k tématu, komunikační } \\
\text { role, projevy a aktivity }\end{array}$} & \multicolumn{2}{|c|}{$\begin{array}{l}M \text { - participanti (R), } \\
M \text { - respondenti (RR), } \\
\text { R - RR vzájemně, } \\
R \text { - moderátor }(M), \\
\text { RR - moderátor (M) } \\
\text { (popis skupinové } \\
\text { dynamiky) }\end{array}$} \\
\hline \multirow[t]{2}{*}{$\begin{array}{l}\text { Problémy } \\
\text { obecné }\end{array}$} & \multicolumn{2}{|c|}{$\begin{array}{l}\text { Selhání role moderáto- } \\
\text { ra, příliš zjevný záměr, } \\
\text { manipulativní jednání, } \\
\text { neotevírající otázky, } \\
\text { nízká míra empatie }\end{array}$} & \multicolumn{2}{|c|}{$\begin{array}{l}\text { Neproduktivní skupina, } \\
\text { sociálně žádoucí odpo- } \\
\text { vědi, odklon od tématu, } \\
\text { kategoriální soudy, } \\
\text { dominantní jednání } \\
\text { jednotlivců }\end{array}$} & \multicolumn{2}{|c|}{$\begin{array}{l}\text { Nezahoření synergického } \\
\text { efektu velká závislost na } \\
\text { moderující osobě, nežá- } \\
\text { doucí směry interakce } \\
\text { a tématu }\end{array}$} \\
\hline & \multicolumn{6}{|c|}{$\begin{array}{l}\text { Nepřehlédnutelná náročnost, nároky na př́ípravu a profesionalitu, nevhodné } \\
\text { prostředí - čas, nevhodná metoda analýzy dat... }\end{array}$} \\
\hline Data & \multicolumn{2}{|c|}{$\begin{array}{l}\text { Snímání a záznam dění } \\
\text { ve focus group }\end{array}$} & \multicolumn{2}{|c|}{$\begin{array}{l}\text { Výzkum analytický x } \\
\text { interpretativní, textový } \\
\text { převod, kódování podle } \\
\text { analytické metody }\end{array}$} & \multicolumn{2}{|c|}{$\begin{array}{l}\text { Výsled. interpretace, } \\
\text { př́ípadové a narativní } \\
\text { studie, možnosti - meze - } \\
\text { optimalizace }\end{array}$} \\
\hline
\end{tabular}

Tab. 6.2: Procedura focus group a její základní charakteristiky (Svatoš, 2010, s. 29) 


\section{7/ \\ VÝZKUMY SELF-EFFICACY STUDENTŮ UČITELSTVÍ V ADAPTAČNÍ ETAPĚ STUDIA}

V následujících částech monografie uvádíme dvě ukázky dvou výzkumů studentů učitelství, v různych oborech. První výzkum byl realizován u studentů učitelství mateřských škol s využitím kvantitativního designu výzkumu a druhý výzkum byl realizován u studentů učitelství ve vybraných aprobacích v kvalitativním designu.

\section{1}

\section{Zkoumání self-efficacy u budoucích učitelů mateřských škol}

V následujících řádcích prezentujeme výzkum, který vznikl jako pokračování výzkumného sledování self-efficacy učitelů. V této části se budeme věnovat specificky učitelům mateřských škol, resp. studentům, kteří se na tuto profesi připravují.

\subsection{1}

\section{Zjišt'ování self-efficacy učitelů}

Jak jsme již v předcházejících kapitolách uvedli, převládajícími metodami zkoumání self-efficacy učitelů je sebehodnotící dotazník se škálami. Prostřednictvím položek v dotazníku respondenti hodnotí svou úroveň přesvědčení o schopnostech učit a působit ve třídě.

Na sledování a měření self-efficacy bylo adaptováno mnoho dotazníků, které měří osobní zdatnost učitelů od předškolního, školního až vysokoškolského stupně. Dva z nich hrály ve výzkumu self-efficacy významnější roli, dotazník TES Gibsona, \& Dembu (1984) a dotazník OSTES Tschannen-Moranové, \& Woolfolk 
Hoyové (2001). Ukázalo se, že ty to dotazníky mají kolísavou faktorovu strukturu a mají tedy problematickou validitu. Mnoho výzkumníků vidělo řešení problémů $s$ validitou měření self-efficacy ve vývoji vlastních výzkumných nástrojů. Ty slouží konkrétním potřebám, jsou věrné jisté teoretické orientaci a odrážejí specifické vzdělávací podmínky země, ve které byly aplikovány. Takové nástroje konstruovaly např. Seo, \& Moon (2012), Gau, \& Hung (2014) a Nikolopoulou, \& Gialamas (2015).

I ve výzkumu, který v této části monografie představujeme, byl využit princip tvorby vlastního výzkumného nástroje, tentokrát nástroje na zjišt'ování self-efficacy budoucích učitelů mateřských škol. Sledování těchto subjektů má pro účinnost vysokoškolské př́ípravy velký význam. Fakulty, které zabezpečují vzdělávání budoucích učitelů mateřských škol, by měly věnovat pozornost self-efficacy svých studentů a sledovat i její vývoj v průběhu vysokoškolského studia. Vysokoškolští učitelé by si měli být vědomi změn self-efficacy během realizace studijního programu a měli by se snažit formovat jeho vývoj. Za tímto účelem musí mít k dispozici validní a reliabilní nástroj pro měření self-efficacy studentů.

\subsection{2}

\section{Metodologie výzkumu}

Cílem výzkumu je představit proces vývoje a validace nástroje pro měření self-efficacy studentů, budoucích učitelů mateřských škol, v průběhu pregraduální přípravy na univerzitě. Zjistili jsme, že je důležitější soustředit se na zkoumání self-efficacy studentů než na zjišt'ování self-efficacy jejich učitelů, tedy akademických pracovníků, protože pro akademické pracovníky to může být důležitý faktor pro směřování studijních programů.

Námi předkládaný nástroj se soustřed'uje na měření self-efficacy s důrazem na základní aspekty vzdělávacích strategií učitelů mateřských škol. Dotazník se nesoustřed'uje na konkrétní oblasti edukace v mateřské škole, jako jsou např́íklad předmatematické představy, nebo jazyková a literární gramotnost. Je konstruován napřríc těmito doménami, čímž poskytuje obecný pohled na self-efficacy studentů, budoucích učitelů mateřských škol. Naším cílem tedy bylo zkonstruovat nástroj, který má uspokojivé psychometrické vlastnosti a je snadno použitelný.

\section{Výzkumný vzorek}

Soubor tvořilo 154 studentů, budoucích učitelů mateřských škol ze dvou českých vysokých škol (Brno a Zlín), kteří byli zapsáni do tř́letého bakalářského programu Učitelství pro mateřské školy. Složení vzorku, pokud jde o semestry, bylo následující: $41,6 \%$ v prvním semestru, $24 \%$ ve třetím semestru a 34,4 \% v pátém semestru. 
Kromě 2 respondentů byly všechny ženy. Z hlediska demografických charakteristik zahrnuje vzorek typické studenty pregraduálního vzdělávání v České republice.

V průběhu bakalářského studia se studenti účastnili přednášek a seminářů z pedagogické teorie i psychologických disciplín. $V$ předškolním zařízení měli také strukturovanou odbornou praxi.

Jejich praxe, tak jak jsme to již popisovali v kapitole 5.2 , byla tradičně dělena na typy praxí podle ročníku a semestru jejich studia. V prvním semestru měli studenti tzv. náslechovou praxi, skrze níž se seznámili s režimem práce učitele v mateřské škole. Během druhého semestru měli dvouhodinové denní pozorování předškolních tříd; ve třetím semestru měli pozorování zaměřené na výuku ve specifických oblastech kurikula; ve čtvrtém semestru učili děti pod dohledem odborníků/metodiků praxí s důrazem na specifickou oblast kurikula; a v pátém semestru prováděli studenti čtyřtýdenní, souvislou praxi.

Anonymita dotazníku byla zajištěna tím, že studenti byli žádáni, aby do formulářů dotazníků neuváděli své jméno. Zjištovali jsme pouze demografické údaje: pohlaví, semestr studia a studovanou univerzitu.

\section{Výzkumný nástroj}

Pro účely tohoto šetření byl vyvinut nástroj pro měření self-efficacy budoucích učitelů mateřských škol - studentů, kteří studovali ve studijním programu Učitelství pro mateřské školy. Výzkumný nástroj, dále označovaný jako SEPRES (Self Efficacy - PREschool), byl vytvořen v souladu s principy teorie Bandury (2006). Konstrukce SEPRES prošla několika fázemi.

V prvním kole jsme vytvořili soubor 100 položek, které byly odvozeny ze tří zdrojů:

a) z literatury o úspěšných přístupech ve vzdělávání učitelů mateřských škol,

b) z kurikulárních dokumentů pro předškolní vzdělávání v České republice,

c) ze zkušenosti autorů v této oblasti.

Ve druhém kole byly položky zkontrolovány třemi odborníky v oblasti předškolního vzdělávání, kteří hodnotili jejich obsahovou validitu. Přesněji řečeno, hodnotili relevanci a jasnost každé položky. V tomto procesu bylo 44 položek vyřazeno jako nedůležité nebo matoucí. Zbývajících 55 položek bylo považováno za relevantní pro tento nástroj.

Každá položka měli napsanou pozitivní formulaci a zahrnovala šestibodovou stupnici s koncovými body „Nemám žádné schopnosti“ a „Mám vysokou schopnost“. Zadání znělo: Předkládáme vám seznam činností a prosíme vás, abyste vyjádřil(a) míru svého přesvědčení ve své schopnosti dané činnosti vykonávat. Můžete odpovědět v rozmezí od 1 (nemám žádné schopnosti) do 6 (mám velké schopnosti). 
Př́íklady položek:

\begin{tabular}{|l|l|l|l|l|l|l|}
\hline Zvládnout chování problémových dětí & 1 & 2 & 3 & 4 & 5 & 6 \\
\hline Odhadnout emocionální potřeby dítěte & 1 & 2 & 3 & 4 & 5 & 6 \\
\hline Vymýšlet tvořivé hry & 1 & 2 & 3 & 4 & 5 & 6 \\
\hline
\end{tabular}

V dalším kole konstrukce dotazníku byl soubor 55 položek dotazníku faktorově analyzován u souboru studentů, který je popsán výše. Faktorová analýza je metoda kondenzace dat do relativně malého počtu faktorů, které přesto vysvětlují velkou část celkového rozptylu dat (Kline, 2000). Obvyklou součástí postupu faktorové analýzy je výpočet celkové variance vysvětlené extrahovanými faktory. Na začátku byla vypočtena míra KMO a Bartlettův test k posouzení, zda jsou data vhodná pro faktorovou analýzu.

Hodnota KMO byla 0,870 a Bartlettův $\mathrm{Chi}^{2}$ byl 5028,140; $\mathrm{df}=1225$, což bylo významné na úrovni $1 \%$. Oba indexy přinesly př́íznivé výsledky, což umožnilo zahájení faktorové analýzy.

Dalším krokem bylo stanovení metody extrakce faktorů. Software IBM SPSS nabízí 7 metod extrakce. Vybrali jsme metodu Principal axis factoring, která nevyžaduje velké vzorky a je tolerantní k normálnosti distribuce dat. Při stanovení počtu extrahovaných faktorů jsme použili kritéria vlastní hodnoty 1 a sutinový graf. Podle prvního kritéria dvanáct faktorů překročilo vlastní hodnotu 1, což by vy tvořilo př́liš mnoho faktorů pro smysluplnou interpretaci. Sutinový graf ukázal na 3, 4 nebo 6 možných faktorů. Faktorové extrakce položek byly nastaveny na 0,40 u všech tř́i možností.

Nejlepší výsledek byl se čtyřmi faktory. Abychom dosáhli co nejlepšího interpretovatelného faktorového modelu, faktory byly rotovány pomocí metody Oblimin. Výsledek rotace je uveden v tabulce 4. Položky s faktorovým zatížením pod 0,40 a položky se zátěží ve dvou nebo více faktorech, které byly vyřazeny, v tabulce nejsou uvedeny. 


\section{Znění položek}

Zvládnout chování problémových dětí.

Udržet pozornost dětí v dané činnosti.

Dosáhnout, aby děti chodily rády do mateřské školy.

Motivovat děti k činnosti, i když nemají zájem.

Zvládnout děti, které vyrušují.

Zabránit problémovému chování dětí.

Vytvořit dětem bezpečné (neohrožující) prostředí.

Organizovat činnosti tak, aby byly přiměřené věku dětí.

Dávat dětem příležitost projevovat svou iniciativu.

Vytvářet příležitosti, aby děti samostatně pracovaly ve skupině.

Dávat dětem př́ležitost vyjádřit své názory.

Vytvářet prostředí, ve kterém děti respektují jeden druhého.

Trpělivě komunikovat s rodiči dítěte.

Používat jazyk, kterému děti rozumějí.

Vytvářet př́ležitosti, aby děti samostatně hledaly řešení úkolů.

Být spravedlivá k dětem.

Rozvíjet u dětí fantazii.

Vytvářet podmínky pro pohybové aktivity dětí.

Rozvíjet u dětí tvořivost.

Podporovat vzájemné učení dětí.

Vytvářet ve třídě jasná pravidla.

Dávat dětem prostor na jejich otázky.

\section{Faktor}

\begin{tabular}{|l|l|l|l}
\hline 1 & 2 & 3 & 4 \\
\hline
\end{tabular}

4

0.664

0.534
0.616

0.833

0.772

$-0.560$

\subsection{3}

\begin{tabular}{l|l|l|}
\hline & & -0.560 \\
\hline
\end{tabular}

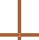

0.558

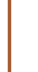

0.681

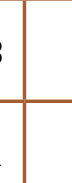

0.541

\begin{tabular}{l|l|l} 
& & \\
\hline & & \\
\hline & & -0.405 \\
\hline
\end{tabular}

-

\begin{tabular}{|c|c|c|}
\hline & 0.511 & \\
\hline 0.414 & & \\
\hline \multirow[t]{2}{*}{0.510} & & \\
\hline & & -0.511 \\
\hline \multicolumn{3}{|l|}{0.608} \\
\hline \multicolumn{3}{|l|}{0.473} \\
\hline \multicolumn{3}{|l|}{0.695} \\
\hline \multicolumn{3}{|l|}{0.630} \\
\hline \multicolumn{3}{|l|}{0.427} \\
\hline & & -0.566 \\
\hline
\end{tabular}




\section{Znění položek}

Spolupracovat s psychologem v případě problémů dítěte.

Spolupracovat s logopedem v případě problémů dítěte.

Obeznámit rodiče s výsledky učení dítěte.

Vymýšlet strategie spolupráce s rodiči.

Spolupracovat s kolegy na tvorbě školního vzdělávacího programu.

Analyzovat a interpretovat dětské výtvory. Spolupracovat s kolegy při řešení výchovných problémů dětí.

Komunikovat citlivě s rodiči o dítěti.

Podporovat vzájemnou pomoc dětí při činnosti.

Spolupracovat s pediatrem.

Zapojit děti do společné činnosti, i když nemají zájem.

Vysvětlená variance

Alfa

Pozn. N = 154; metoda Principal axis factoring; rotace Oblimin; Alfa = Cronbachův koeficient reliability

\begin{tabular}{|c|c|c|c|}
\hline 1 & 2 & 3 & 4 \\
& & 0.749 & \\
\hline
\end{tabular}

\begin{tabular}{|l|l|l|l|} 
& & 0.633 & \\
\hline & & 0.552 & \\
\hline & & 0.654 & \\
\hline
\end{tabular}

\begin{tabular}{|l|l|l|l|} 
& & 0.654 & \\
\hline 0.466 & & 0.506 & \\
\hline
\end{tabular}

\section{Faktor}

\section{Tab. 7.1: Znění položek, faktory a faktorové zátěže dotazníku SEPRES}

Abychom shrnuli proces redukce položek, začali jsme s bankou 100 položek, z nichž bylo 77 vyřazeno ve dvou kolech: 45 v prvním a 22 ve druhém. To potvrdilo princip DeVellise (2003), že konstrukce škálového dotazníku vyžaduje banku položek třikrát nebo čtyřikrát větší, než je konečná délka dotazníku. Díky robustnímu počtu má výzkumník dostatek položek, které mohou být vybrány v následujících kolech analýzy, aby byl získán validní a reliabilní výzkumný nástroj.

Výsledkem faktorové analýzy bylo 33 získaných položek rozdělených do čtyř faktorů, které celkem vysvětlují 45 \% společné variace.

1. První faktor byl pojmenován Zapojení dětí a soustřed'uje se na činnosti učitele, které podporují zapojení dětí do aktivit v mateřské škole. Místo toho, aby 
dotazník respondenty žádal hodnotit své přesvědčení pro vzdělávání podle konkrétních vzdělávacích oblastí, soustředil se na obecnější prvky, například „Podporovat vzájemné učení dětí“ nebo „Poskytovat dětem př́ležitost vyjádřit svůj názor" (13 položek, reliabilita Cronbachova Alfa 0,903).

2. Druhý faktor byl pojmenován Odstranění nepřiměřeného chování dětí. Týká se eliminace nevhodného chování dětí nebo a obsahuje položky jako „Zabránit problémovému chování dětí“ nebo „Zapojit děti do společné činnosti, i když nemají zájem" (6 položek, reliabilita Cronbachova Alfa 0,859).

3. Třetí faktor byl pojmenován Odborná spolupráce učitele. Zahrnuje spolupráci učitelů s odborníky, jako jsou psycholog, logoped a pediatr při řešení psychologických, sociálních a zdravotních problémů dětí. Zahrnuje také spolupráci s kolegy v předškolním zařízení týkající se odborných záležitostí a komunikaci s rodiči dětí, které předškolní zařízení navštěvují. Faktor dále obsahuje položky týkající se spolupráce učitele s rodiči. Faktor zahrnuje položky jako „Komunikace s psychologem, pokud nastanou problémy s dítětem“, „Spolupráce s kolegy na konstrukci předškolního kurikula“ a „Trpělivá komunikace s rodiči“ (9 položek, reliabilita Cronbachova Alfa 0,886).

4. Čtvrtý faktor byl pojmenován Budování důvěry. Jedná se o nastolení důvěry dětí v učitele vytvořením př́ijemného klimatu a neubližujícího prostředív mateřské škole. Skládá se z položek jako „Vytvářet prostředí, ve kterém děti respektují jeden druhého“ nebo „Být spravedlivý(á) k dětem“ (5 položek, Alfa 0,769).

Čtyři faktory získané poskytují dobrou základnu pro konstruktovou validitu dotazníku. Představují vhodný profil učitelských aktivit zaměřených jak na děti (faktory 1, 2 a 4), tak na kolegy a rodiče, se kterými učitelé spolupracují (faktor 3). Odpovědí respondentů o jejich self-efficacy ve výuce ve tř́ídě (faktory 1, 2 a 4) i mimo ni (faktor 3) jsou proto dobrým obrazem jejich přesvědčení v těchto oblastech.

Pokud jde o reliabilitu dotazníku, Alfa u těch faktorů byla nad 0,86 což je dostatečný údaj pro dotazník tohoto typu a u jedné byla 0,77 . Důvodem pro nižší koeficient u tohoto faktoru je zřejmě nízký počet položek.

Další důkazy o validitě dotazníku byly získány zkoumáním vzájemných korelací mezi dimenzemi (tabulka 7.2). (Tady již označujeme faktory spíše jako „dimenze dotazníku“ než jako "faktory“, protože nyní se pohybujeme již mimo vlastní faktorovou analýzu.) Všechny dimenze jsou pozitivně korelované se středně vysokými koeficienty. To naznačuje, že self-efficacy je u respondentů ve čtyřech dimenzích propojena a vytváří jistý systém. Korelace dimenze Zapojení dětí s dimenzí Budování důvěry přinesla nejvyšší korelaci $(0,681)$, což naznačuje, že jsou tady vztahy nejužší. Přístup učitele k dětem musí být skutečně přesvědčivý a musí je přitahovat, aby byly zapojeny do spolupráce jak s učitelem, tak s jinými dětmi ve skupině. 
Téměř stejně vysoká korelace byla mezi dimenzí Zapojení dětí a dimenzí Odborná spolupráce $(0,641)$, což naznačuje úzký vztah v přesvědčení, že budou v těchto dvou oblastech úspěšně jednat ve své pozdější praxi. Dimenze Zapojení dětí byla dále pozitivně korelována s dimenzí Odstranění nepřiměreného špatného chování $(0,510)$.

Tento vztah lze obhájit z toho důvodu, že pokud má učitel silnou schopnost řídit výukové aktivity dětí, má také potenciál zredukovat nebo eliminovat rušivé chování.

Dále byla zjištěna pozitivní korelace mezi dimenzí Odstranění nepřiměřeného chování a dimenzí Budování duvěry u dětí $(0,562)$. Pokud učitel věří ve své schopnosti zvládat nevhodné chování, existuje šance, že věří také ve schopnost budovat svou důvěru v děti.

Nejslabší korelace byla identifikována mezi dimenzí Odstranění nepřiměřeného chování dimenzí a Odbornou spoluprácí $(0,434)$, což ukazuje určitou souvislost mezi prací učitele s problémovou situací ve třídě a odbornými radami od kolegů a komunikací s rodiči. Korelace mezi dimenzí Budování důvěry a dimenzí Odborná spolupráce byla 0,526 a ukazuje, že práce s dětmi a komunikace s odborníky má zřejmou souvislost. Celkově vzájemné korelace mezi faktory naznačují dobrou validitu dotazníku. Vztahy mezi dimenzemi jsou teoreticky smysluplné, což podporuje koncepční jednotu dotazníku.

Tab. 7.2: Vzájemné korelace mezi dimenzemi dotazníku SEPRES (Spermanovo rho)

\begin{tabular}{|l|c|c|c|}
\hline & $\begin{array}{c}\text { Odstranění } \\
\text { nepřiměřeného } \\
\text { chování }\end{array}$ & $\begin{array}{c}\text { Odborná } \\
\text { spolupráce }\end{array}$ & $\begin{array}{c}\text { Budování } \\
\text { důvěry }\end{array}$ \\
\hline Zapojení dětí & 0.510 & 0.641 & 0.681 \\
\hline $\begin{array}{l}\text { Odstranění } \\
\text { nepřiměřeného chování }\end{array}$ & & 0.434 & 0.562 \\
\hline Odborná spolupráce & & & 0.526 \\
\hline
\end{tabular}

Pozn.: V̌̌echny korelace jsou významné na úrovni 0,01.

\section{Stručná interpretace dat}

Tabulka 3 uvádí popisné výsledky dotazníku SEPRES. Průměry ve všech dimenzích jsou relativně vysoké. To zřejmě ukazuje i údaj o indexu Shapiro-Wilk. Normální distribuce dat je v dimenzi Odstranění nepřiměřeného chování, v dalších dimenzích se data se poněkud odchylují od normálního rozdělení. Špičatost distribuce je vychýlena směrem k vyšším hodnotám v odpovědích respondentů. 
Průměry odpovědí ve všech dimenzích překračují střed šestibodové stupnice, což naznačuje, že si studenti jsou docela jisti svým potenciálem učit v mateřské škole. Mají optimistický pohled na své schopnosti organizovat výuku, řídit třídu dětí a spolupracovat s kolegy a rodiči. Tento optimismus je sice zdravý, ale lze ho připsat spíš nedostatku zkušeností v konkrétních situacích se vzděláváním dětí předškolního věku. Reálná praxe může, ale taky nemusí,snížit jejich self-efficacy. Výzkumy ovšem většinou ukazují, že učitelé v praxi mají též tendenci hodnotit své přesvědčení o schopnosti vykonávat činnosti ve třídě nad středovou polohou škály (Tschannen-Moran, \& Woolfolk Hoy, 2001).

Nejvyššího skóre bylo dosaženo v dimenzi Budování důvěry. Respondenti pevně věří ve schopnosti vytvářet bezpečné vzdělávací prostředí, podporovat respekt mezi dětmi a být $\mathrm{k}$ dětem spravedliví. Tato víra je silnější než vytváření vzdělávacího prostředí, které zahrnuje děti do aktivit (dimenze Zapojení dětí), ale rozdíl mezi skóre těchto dvou dimenzí je poměrně malé. Odstranění nepřiměřeného chování dětí má nejnižší průměr ze všech čtyř dimenzí, což ukazuje, že respondenti si uvědomují, že tento prvek v činnosti učitelů je nejobtížnější. Respondenti zaznamenali o něco nižší hodnocení v dimenzi Odborná spolupráce než ve dvou dalších dvou dimenzích chování učitelů, tj. Zapojení dětí a Budování důvěry.

Tab. 7.3: Deskriptivní data dotazníku SEPRES

\begin{tabular}{|l|c|c|c|c|}
\hline & $\mathrm{N}$ & $\mathrm{M}$ & $\mathrm{SD}$ & Shapiro-Wilk's p \\
\hline Zapojení dětí & 154 & 4.83 & 0.63 & 0,00 \\
\hline $\begin{array}{l}\text { Odstranění } \\
\text { nepřiměřeného chování }\end{array}$ & 153 & 3.96 & 0.75 & $0,08+$ \\
\hline Odborná spolupráce & 154 & 4.58 & 0.79 & 0,001 \\
\hline Budování důvěry & 154 & 5.05 & 0.61 & 0,001 \\
\hline
\end{tabular}

Pozn.: $N$ = počet respondentů; škála od 1 do 6; $M$ = aritmetický průměr; $S D$ = standardní odchylka; Shapiro -Wilk's $p=$ test normality rozložení dat

Zajímavé zjištění se týká průměrů podle semestrů bakalářského programu. Obrázek 8 ukazuje dva trendy. Průměr self-efficacy v každém semestru odráží stejný trend jako skóre celého vzorku respondentů. V každém semestru bylo nejvyšší skóre v dimenzi Budování důvěryhodnosti, následované dimenzí Zapojení dětí a Odbornou spoluprací. Nejnižší skóre bylo v dimenzi Odstranění nepřiměřeného chování. Tento konzistentní vzorec průměrů v celém dotazníku SEPRES je dalším důkazem validity dotazníku. Rozdíly v průměrech mezi semestry jsou navíc malé, což naznačuje, že v průběhu bakalářského studia nedochází k rozhodující změně 
této charakteristiky studentů. Očekávali jsme spíše nárůst průměru v každém semestru kvůli rostoucí kompetenci studentů získané prostřednictvím přednášek, seminářů a praxe v terénu. To se nepotvrdilo. Nejpravděpodobnějším vysvětlením je, že studenti měli vysokou self-efficacy již v prvním semestru, takže další zvýšení byla v následujících semestrech nepravděpodobná.

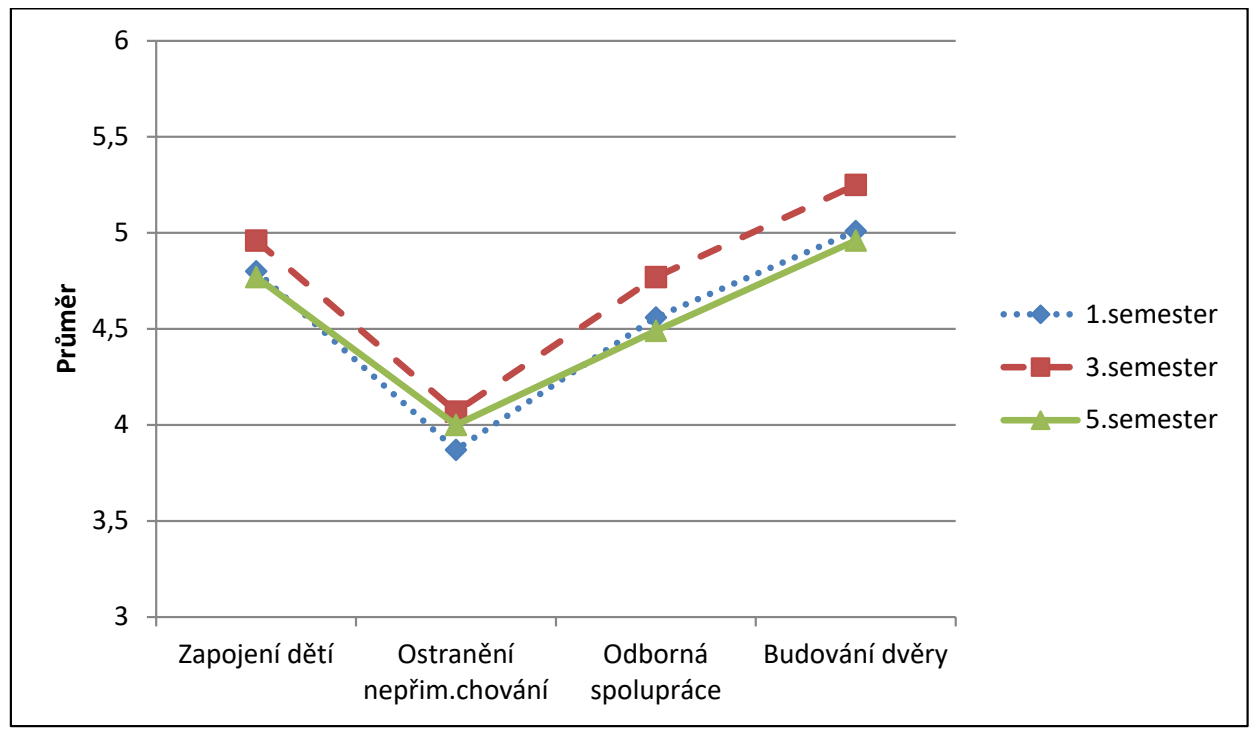

Obr. 8: Průměry jednotlivých dimenzí v dotazníku SEPRES v semestrech bakalářského studijního programu

Položky dotazníku s nejvyšším a nejnižším průměrem

Výsledky podle dimenzí, a pak podle semestrů studia, byly důležitými ukazateli konstruktových vlastností dotazníku. Pedagogy ovšem také zajímalo, jak respondenti hodnotili jednotlivé položky dotazníku. Pro tento účel jsme vybrali ty položky, které měly nejvyšší průměr a položky, které naopak měly nejnižší průměr. Ukazují tak v kterých činnostech mají respondenti nejvyšší a nejnižší důvěru ve své vzdělávací schopnosti. Kritériem pro první kategorii byly položky, které na použité šestibodové škále dotazníku překročily průměrnou hodnotu 5 , druhou kategorii reprezentovaly položky, které měly průměr nižší jako 3,99. Údaje ukazuje Tabulka 7.4.

Podle tabulky je v první kategorii o něco více položek nežli ve druhé. Nejvyšší průměr měla položka, která se týkala vhodné komunikace s dětmi, k čemu slouží srozumitelný jazyk. Ten je základní podmínkou fungování „pracovních“ vztahů 
mezi učitelkou a dětmi. Pohybové aktivity patří mezi lehčí práci učitelky, protože děti je rády vykonávají a rychle je zaujmou - proto ten vysoký průměr. Spravedlivé chování učitelky je důležitou stránkou jejího fungování s dětmi, proto musíme ocenit, že ho respondenti hodnotili vysoko. Dvě položky se týkaly otevírání příležitostí dětem, a to umožňovat projevy vlastní iniciativy a možnost kladení otázek. V obou př́ípadech se učitelky vzdávají části své moci a odevzdávají ji dětem. Vytvořit bezpečné prostředí si vyžaduje neustálé monitorování prostředí mateřské školy a dění ve třídě, aby vzdělávací proces probíhal v efektivním rámci a aby nedošlo ke zranění dětí.

Pokud jde o položky s nejnižším průměrem, tři se týkaly zvládání dětí (problémové děti, děti s problémovým chováním a vyrušující děti). Je zřejmé, že zvládat tyto děti je náročné, proto nižší hodnocení schopností v této oblasti. Jedna položka se týkala umožnění dětem vyjádřit své názory. Učitelky tuto schopnost hodnotily níže než iniciování dětem klást otázky. Rozdíl vyjadřuje zřejmě diferenci mezi otázkami a názorem. Na otázku odpovídá někdo druhý, vyslovení názoru je úloha pro osloveného.

Tab. 7.4: Položky dotazníku SEPRES s nejvyšším a nejnižším průměrem

\begin{tabular}{|l|c|}
\hline Položky s nejvyšším průměrem & $\mathrm{M}$ \\
\hline Vytvořit dětem bezpečné (neohrožující) prostředí. & 5,19 \\
\hline Dávat dětem prostor na jejich otázky. & 5,31 \\
\hline Dávat dětem příležitost projevovat svou iniciativu. & 5,32 \\
\hline Být spravedlivá k dětem. & 5,32 \\
\hline Vytvářet podmínky pro pohybové aktivity dětí. & 5,50 \\
\hline Používat jazyk, kterému děti rozumějí. & 5,60 \\
\hline & \\
\hline Položky s najnižším průměrem & \\
\hline Zvládnout chování problémových dětí. & 3,62 \\
\hline Dávat dětem příležitost vyjádřit své názory. & 3,74 \\
\hline Zvládat děti, které vyrušují. & 3,92 \\
\hline Zabránit problémovému chování dětí. & 3,95 \\
\hline
\end{tabular}

Pozn.: $M=$ aritmetický průměr

\section{Diskuse}

Hlavním cílem kapitoly bylo představit konstrukci a validaci dotazníku SEPRES zaměřeného na měření self-efficacy studentů předškolního vzdělávání v bakalářském 
programu Učitelství pro mateřské školy. Po vygenerování položek dotazníku pro banku položek byly položky ověřeny z hlediska obsahu a poté byly analyzovány faktory, aby se určila konstruktová validita dotazníku. Jako nejlépe interpretovatelné řešení ve faktorové analýze byla stanovena čtyřfaktorová struktura obsahující 33 položek. Dimenze mají uspokojivou reliabilitu. Celkově má SEPRES slibné psychometrické vlastnosti a lze jej doporučit pro použití v dalších výzkumech studentů, kteří studují ve studijním programu Učitelství pro mateřské školy.

Interkorelace mezi dimenzemi naznačuje, že dimenze jsou poměrně úzce propojeny. Tento nález je častý i v jiných studiích self-efficacy s různými soubory učitelů (Tschannen-Moran, \& Woolfolk Hoy, 2001; Jamil et al., 2012) za podmínky, že dimenze dotazníku jsou založeny na jednotném teoretickém konceptu. Pokud je dotazník koncepčně různorodý, interkorelace mezi faktory jsou malé. To platí například pro dotazník TES (Gibson, \& Dembo, 1984), který má jeden faktor založený na Bandurově konceptu přesvědčení o vlastních schopnostech vykonávat určitou činnost a druhý založený na teorii lokalizace rozhodujícího vlivu (locus of control) J. B. Rottera (1996).

Mnoho dalších studií zjistilo podobně vysokou úroveň self-efficacy u učitelů nebo studentů v programech předškolního vzdělávání, a to bez ohledu na konstrukci použitého výzkumného nástroje, demografické složení vzorku a zemi, z níž pochází. Relativně vysoká úroveň self-efficacy u studentů učitelství byla zjištěna např́íklad ve Spojených státech (Woolfolk Hoy, \& Spero, 2005), v Turecku (Cakiroglu, Cakiroglu, \& Boone, 2005), na Kypru (Charalambous, \& Philippiou, 2007), Koreji (Seo, \& Moon, 2013) a na Slovensku (Gavora, 2010). Vysoké průměry naznačují, že studenti mají spíše optimistický pohled na své schopnosti zvládat složitost procesu předškolního vzdělávání. To se však může změnit poté, co vstoupí do předškolní profese a budou konfrontováni s každodenními povinnostmi učitelů na plný úvazek.

Podle A. Bandury (1993) self-efficacy ukazuje, jak lidé věří ve své schopnosti a podle toho se motivují, proto self-efficacy je jedna z nejsilnějších profesních charakteristik učitelů. Přes svůj význam v profesním rozvoji učitelů byla u učitelů mateřských škol málo zkoumána (Guo et al., 2011). Ještě méně to byla zkoumána u budoucích učitelů mateřských škol. Dotazník SEPRES ukázal dobrou validitu a reliabilitu a může tedy sloužit jako nástroj v dalších šetřeních.

\section{2}

\section{Self efficacy studentů učitelství vybraných aprobací}

Kvalitativní cestu při sledování, resp. zjištování self-efficacy jsme uplatnili ve výzkumu pomocí fokusové skupiny studentů. 
Cílem aplikace metody focus group v našich podmínkách bylo uskutečnit interview se začínajícími vysokoškoláky a zjistit míru, rozsah a hloubku jejich poznatků o self-efficacy, a to jako obecné teoretické téma, tak i jako téma, o kterém osobitě uvažují a ztotožňují se s jeho principy. Několikrát jsme zdůvodňovali volbu právě této osobité semiprofesní skupiny; jde o homogenní vrstevnickou skupinu, která je v adolescentním stádiu vývoje a vykazuje obdobné psychické a sociální vlastnosti. Nicméně každý participant měl svou „lidskou“ minulost, své představy o sobě samém i vize o budoucím studiu a následném povolání. Pohledem profesionalizačních etap se studenti nacházeli na startu cesty k učitelství, byli v adaptační fázi sžívání se akademickým prostředím i dalšími studenty. Jejich pedagogická praxe byla na počátku spíše formou náslechovou. Až na výjimky se jednalo o „nedávné maturanty“, kteří neměli předchozí zkušenosti s vysokoškolským studiem, nebo rolí nekvalifikovaného učitele.

Moderující osobou výzkumu byl student-výzkumník, který se dlouhodobě zajímal o problematiku self-efficacy, což lze doložit jeho pracemi (Linke, 2013, 2014 a 2016). Moderátor měl dlouhodobější zkušenosti s komunikací osob ve skupině a splňoval základní požadavky na tuto specifickou roli. Je třeba dodat, že jeho příprava sestávala z předem stanové obsahové struktury a vycházela z predikovaných výzkumných otázek. Záznamy dění v ohniskových skupinách prokázaly, že moderátor svou roli zvládal a inicioval citlivě a pohotově v interakci s respondenty. Focus group se uskutečnily v nevýukovém prostředí jedné vysoké školy. Jednalo se o střídmě vybavenou pracovnu, kde u jednoho stolu seděli respondenti tak, aby mohli vizuálně sledovat ostatní a žádný z přítomných nebyl v preferujícím, nebo submisivním posezení. Ilustrujeme na obrázku č. 9.

Dění ve focus group bylo snímáno a zaznamenáno videokamerou, kterou obsluhoval vedoucí výzkumného týmu - s mnohaletými zkušenostmi s aplikacemi televizní techniky ve studiu učitelství. Kamera byla umístěna v pozadí mimo hlavní zorné pole respondentů, moderátor seděl stranou poblíž diskutujících osob. Není bez zajímavosti, že téměř všichni respondenti projevili zájem „se vidět“ a někteří si odnášeli kopii záznamu diskuse na svých mediálních nosičích. Zbývá dodat, že obvyklá doba interview v ohniskových skupinách byla 50 - 55 minut a vycházela z přirozené potřeby dialog ukončit - po vyčerpání jeho obsahu. Videonahrávky byly časově nezávislými zdroji dat pro další analýzy. Jejich kvalita byla velmi dobrá a umožňovala porozumět verbálním sdělením jak po obsahové stránce, tak i po zvukové stránce řeči. Hovoříme o podmínce úspěšné práce se záznamy, kdy jejich další zpracování spočívá v přepisu (transkripci) verbální komunikace a následném kódování. Analýza výzkumných dat vycházela z konceptu tzv. zakotvené teorie, kdy kódování přecházelo z popisné roviny sdělovaného obsahu k teoretickým konstrukcím, co za popisem stojí a co bylo jeho příčinou. 


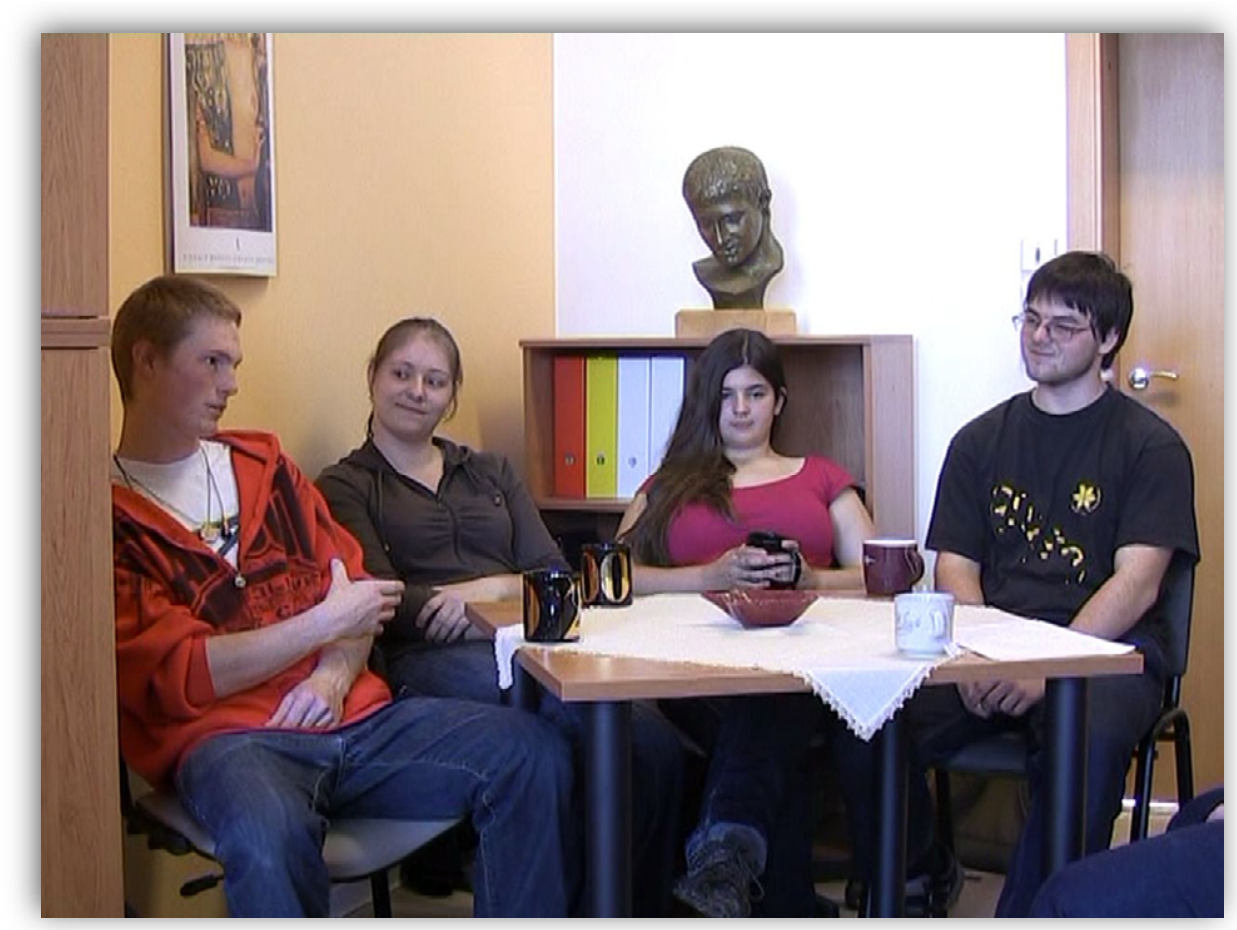

Obr. 9: Participanti v ohniskové skupině

\subsection{1}

\section{Cíle šetření, metodologie výzkumu, participanti výzkumu}

Popisované výzkumné šetření mezi studenty-začátečníky na pedagogické fakultě jedné vysoké školy bylo zaměřeno na odpovědi na tyto hlavní výzkumné otázky: V01: jak lze charakterizovat začínající studenty učitelství vzhledem k self-efficacy? V02: jak jsou začínající studenti schopni pochopit a uchopit koncept self-efficacy? V souvislosti s hlavními cíli výzkumu jsme poté ujasnili vedlejší výzkumné otázky, které se promítly do přípravy dialogu v ohniskových skupinách a tvořili „scénář“ budoucí interakce mezi moderátorem a respondenty.

\section{Vedlejší výzkumné otázky v první k první hlavní výzkumné otázce:}

V01A: jaké měli respondenti předchozí pedagogické zkušenosti (např. zkušenosti s vedením zájmových útvarů) a jistoty těchto rolí?

V01B: jaké motivy převládaly při volbě vysoké škole a nakolik byly osobní volbou? V01C: jak se rodinné prostředí podílelo na budoucí profesní orientaci respondentů? 
V01D: jak respondenti prožívali přechod ze střední školy na školu vysokou? V01E: jaké měli (či mají) pedagogicko-výchovné vzory a nakolik se s nimi ztotožňují?

\section{Vedlejší výzkumné otázky $k$ druhé hlavní výzkumné otázce:}

V02A: je možné, aby míra self-efficacy učitele ovlivnila self-efficacy jeho studentů? V02B: domnívají se respondenti, že se dá self-efficacy záměrně rozvíjet?

VO2C: je reálný předpoklad, že může učitel self-efficacy cíleně rozvíjet u svých studentů?

VO2D: považují respondenti za prospěšné, aby koncept self-efficacy byl představen budoucím učitelům v počátku studia v některé z pedagogických disciplín?

VO2E: jak sami respondenti vyjádřili svou osobní míru SE na škále nízká - přiměřená - vysoká?

Po seznámení s konceptem, výzkumy o učitelské self-efficacy a dotazníkem TES Teacher Efficacy Scale, vytvořený autory Gibsnem a Dembem (1984), standardně používaným pro určení míry self-efficacy učitele, jsme vy tvořili scénář pro diskuze v ohniskové skupině, zaměřené na osobně vnímanou zdatnost. Dodejme, že dialog ve focus group byl předem promyšlený a vycházel ze zkušeností s touto specifickou skupinou vysokoškolské populace. Moderátor připravil baterii otevřených otázek, které se shodovaly s hlavními a vedlejšími výzkumnými otázkami. Po formální stránce sestávalo interview v ohniskových skupinách ze tří na sebe vázaných částí.

V první ćásti dialogu přicházely osobnější a adresnější dotazy, které měly odhalit osobně vnímanou zdatnost respondentů na základě jejich předchozích zkušeností a prožitků, na základě vnímání současnosti a konečně i představ o budoucí profesi a jejích představitelích (zaměřeno na první hlavní výzkumnou otázku). Protože se jednalo o začínající studenty učitelských oborů, předpokládali jsme, že alespoň část $\mathrm{z}$ nich už měla nějaké zkušenosti s výchovnou praxí, a to $\mathrm{v}$ rolích vedoucích zájmových kroužků, nebo s doučováním a podobně. Nicméně moderátor v př́ípravě anticipoval odpovědi v širokém spektru a byl připraven i na to, že respondenti nebudou schopni aktivně doložit předchozí pedagogickou zkušenost.

Druhá část dění v ohniskových skupinách byla dílem moderátora, který stručně, ale dostupnými prostředky př́tomným studentům představil koncept self-efficacy a vysvětlil jeho podstatu.

Ve třetí části interview v ohniskových skupinách se zájem soustředil na to, jak respondenti konceptu osobně vnímané zdatnosti porozuměli, nakolik jsou schopni se s ním ztotožnit a promítnout do svého současného osobního i budoucího profesního života. Následovaly iniciace moderátora směrem k představám vztahu pedagoga a self-efficacy, jeho možnostem směrem k rozvoji sebe sama i žáků, se kterými se denně setkává. Posledním tématem bylo zjištění postojů respondentů 
k myšlence, že i oni by se měli v teoretické pedagogicko-psychologické přípravě dozvědět o konceptu osobně vnímané zdatnosti a měli by v rámci pedagogických seminářů procházet postupy jejího rozvoje. Chronologii dění ve focus group zobrazuje tabulka 7.5.

\begin{tabular}{|c|c|c|c|}
\hline Část dialogu & $\begin{array}{l}\text { Činnost moderá- } \\
\text { tora }\end{array}$ & $\begin{array}{l}\text { Činnost partici- } \\
\text { pantů }\end{array}$ & Výstup \\
\hline Motivační & $\begin{array}{l}\text { Zdůvodňuje } \\
\text { setkání, motivuje } \\
\text { a otevírá respon- } \\
\text { denty k dialogu }\end{array}$ & $\begin{array}{l}\text { Seznamují se } \\
\text { s prostředím, } \\
\text { účastníky dialogu } \\
\text { a záměry setkání }\end{array}$ & $\begin{array}{l}\text { Podmínky } \\
\text { k otevřenému } \\
\text { rozhovoru }\end{array}$ \\
\hline Iniciační & $\begin{array}{l}\text { Navozuje volnou } \\
\text { diskusi o jejich } \\
\text { osobní minu- } \\
\text { losti, připomíná } \\
\text { obvyklou genezi } \\
\text { cesty od studen- } \\
\text { ta střední školy } \\
\text { k vysokoškolá- } \\
\text { kovi }\end{array}$ & $\begin{array}{l}\text { Verbalizují svoji } \\
\text { dosavadní životní } \\
\text { dráhu, popisují } \\
\text { motivy profesní } \\
\text { orientace, zvýraz- } \\
\text { ňují osobní podíl } \\
\text { či podíl prostředí } \\
\text { na volbě vysoké } \\
\text { školy }\end{array}$ & $\begin{array}{l}\text { Sebereflexe } \\
\text { dosavadního } \\
\text { života, ujasnění } \\
\text { klíčových } \\
\text { životních } \\
\text { momentů }\end{array}$ \\
\hline $\begin{array}{l}\text { Interpretační } \\
\text { (osobně } \\
\text { vnímaná } \\
\text { zdatnost } \\
\text { z minulé } \\
\text { zkušenosti) }\end{array}$ & $\begin{array}{l}\text { Iniciuje k remi- } \\
\text { niscenci prožitků } \\
\text { respondentů } \\
\text { s ohledem na } \\
\text { jejich dosavadní } \\
\text { pedagogické zku- } \\
\text { šenosti a vybízí } \\
\text { ke sdělení úspěš- } \\
\text { nosti v rolích } \\
\text { vedoucích (vzdě- } \\
\text { lavatelů) }\end{array}$ & $\begin{array}{l}\text { Jednotlivě zdů- } \\
\text { vodňují své do- } \\
\text { savadní pedago- } \\
\text { gické zkušenosti, } \\
\text { popisují úspěchy } \\
\text { i selhání a hledají } \\
\text { příćiny, pojmeno- } \\
\text { vávají podmínky } \\
\text { pro budoucí zdár- } \\
\text { nou činnost na } \\
\text { základě znalosti } \\
\text { sebe sama }\end{array}$ & $\begin{array}{l}\text { Identifikace } \\
\text { a popis osobní } \\
\text { zdatnosti na } \\
\text { základě minulé } \\
\text { zkušenosti } \\
\text { a projekce } \\
\text { do budoucna }\end{array}$ \\
\hline Expoziční & $\begin{array}{l}\text { Vysvětluje pod- } \\
\text { statu konceptu } \\
\text { self-efficacy }\end{array}$ & $\begin{array}{l}\text { Vnímají výklad } \\
\text { a vytvářejí si po- } \\
\text { třebné představy }\end{array}$ & $\begin{array}{l}\text { Objasněný kon- } \\
\text { cept SE }\end{array}$ \\
\hline
\end{tabular}




\begin{tabular}{|c|c|c|c|}
\hline Část dialogu & $\begin{array}{l}\text { Činnost moderá- } \\
\text { tora }\end{array}$ & $\begin{array}{l}\text { Činnost partici- } \\
\text { pantů }\end{array}$ & Výstup \\
\hline $\begin{array}{l}\text { Interpretační } \\
\text { (úvahy o self- } \\
\text { efficacy ve } \\
\text { škole - popis } \\
\text { možností) }\end{array}$ & $\begin{array}{l}\text { Navozuje dia- } \\
\text { log o SE a vede } \\
\text { k myšlenkám } \\
\text { o jeho potenciálu } \\
\text { ve škole, významu } \\
\text { pro v roli učitele } \\
\text { a žáků, o mož- } \\
\text { nostech ovlivnění } \\
\text { a růstu }\end{array}$ & $\begin{array}{l}\text { Vyjadřují před- } \\
\text { stavy a osobní } \\
\text { postoje k možnos- } \\
\text { tem k významu } \\
\text { osobně vnímané } \\
\text { zdatnosti u učite- } \\
\text { lů i žáků, sdělují } \\
\text { názor na teorii SE } \\
\text { ve vysokoškolské } \\
\text { výuce }\end{array}$ & $\begin{array}{l}\text { Porozumění obec- } \\
\text { nému konceptu } \\
\text { SE a jeho aplikace } \\
\text { v podmínkách } \\
\text { vzdělávání }\end{array}$ \\
\hline Rekapitulující & $\begin{array}{l}\text { navození závě- } \\
\text { rečné vícesměrné } \\
\text { interakce o hlav- } \\
\text { ních znacích SE, } \\
\text { jejím osobním } \\
\text { vnímání i význa- } \\
\text { mu v učitelství }\end{array}$ & $\begin{array}{l}\text { rekapitulují své } \\
\text { názory, snaží se } \\
\text { dobrat změn, ke } \\
\text { kterým v průběhu } \\
\text { diskuse došlo, } \\
\text { orientují se na bu- } \\
\text { doucí možnosti SE } \\
\text { v jejich případě }\end{array}$ & $\begin{array}{l}\text { předefinovaná } \\
\text { představa teorie } \\
\text { SE a aplikace na } \\
\text { osobní a profesní } \\
\text { život }\end{array}$ \\
\hline
\end{tabular}

Tab. 7.5: Procedura focus group a její fáze (analogicky podle: Svatoš, \& Švarcová, 2007)

\section{Analýza dat}

Očekávaným metodologickým krokem bylo, že po uskutečnění interview v ohniskových skupinách, resp. pořízení záznamu komunikace, byly nahrávky interakce doslova přepsány a následně analyzovány pomocí otevřeného a axiálního kódování. Pracovali jsme metodou zakotvené teorie - jako jedné z metod analýzy dat kvalitativních šetření. Připomeňme zásadní znaky zakotvené teorie, jak je popisována v dostupné literatuře. Podle Strausse, \& Corbinové (1999, s. 14) jde o „teorii induktivně odvozenou ze zkoumání jevu, který reprezentuje“. Principem jde o shromažd’ování údajů o zkoumaném jevu ze zaznamenaných dat a následné analýze, jejímž záměrem je zjistit, co bylo v „datech“ pro zkoumanou oblast významné. Při analytických postupech se obvykle používá kódování dat, a to ve třech různých podobách: otevřeného kódování - roztřídění údajů do kategorií, axiálního kódování - uvádění vzniklých kategorií do vztahů mezi sebou, a selektivní kódování - nalezení klíčové kategorie a pojmenování souvislostí. 
V našem případě jsme výzkumná data kódovali především prvními dvěma typy. Otevřené kódování je podle Strausse, \& Corbinové (1999, s. 42), „proces rozebírání, prozkoumávání, porovnávání, konceptualizace a kategorizace údajư“. Předpokladem je dostatečné množství shromážděných údajů, které se podle společných charakteristik seskupují do dílčích kategorií. Axiální kódování se provádí následně, kdy se kategorie vzniklé při otevřeném kódování staví do vzájemného vztahu podle jejich logických vazeb. Tyto vazby se následně identifikují. Tím vzniknou seskupení hierarchicky uspořádaných kategorií, které se vztahují k jednomu jevu. K těmto seskupením se, stejně jako v případě kategorií, přiřadí pojmenování, tentokrát širší, než tomu bylo u kategorií. Následuje uspořádání kategorií do jediné linie. Ta obsahuje pouze nejdůležitější kategorie spolu s jejich vzájemnými vztahy, a může být vyjádřena pomocí schématu či grafu. Posledním krokem je interpretace zkoumaných dat. Jedná se o zhodnocení uskutečněného výzkumu a zodpovězení otázek, o čem zjištěná data vypovídají.

\section{Volba focusové skupiny a pravidla interakce}

Jako příklad volby skupiny participantů uvádíme, že v průběhu akademického roku 2015/2016 proběhly čtyři diskuze v ohniskových skupinách, jichž se zúčastnilo dohromady 13 studentů prvního ročníku oborů se zaměřením na vzdělávání, z toho 5 mužů a 8 žen (studujících různé obory se zaměřením na vzdělávání). Jejich výběr byl záměrný a vycházel ze zkušenosti výzkumníka, který byl současně i vyučujícím disciplíny Pedagogická propedeutika. Pro první tři ohniskové skupiny byli vybráni studenti, kteří byli ve výuce aktivní a rádi komunikovali, poslední čtvrtá ohnisková skupina proběhla se studenty ve vyučování méně aktivními. Do interview v ohniskové skupině se zapojili vždy tři až čtyři participanti, moderátor a vedoucí výzkumného výzkumu. Jak jsme již uvedli, diskuze trvala přibližně jednu hodinu a byl z ní pořizován audiovizuální záznam.

Po úvodním vzájemném představení jsme účastníky seznámili s tématem a očekávaným průběhem diskuze, přičemž jsme nezmiňovali samotný pojem self-efficacy. Participanty jsme informovali, že v diskuzi mají možnost na sebe vzájemně reagovat, klást si otázky, diskutovat o svých odpovědích, vyjadřovat souhlas či nesouhlas, navrhovat řešení popisovaných situací atd. Zdůraznili jsme, že je normální uvádět a zdůvodňovat osobní názory, že se nehledá, který z nich je „nejlepší“ či nejvíce sociálně přijatelný a že z žádné odpovědi nebudou vyvozeny (osobní, studijní...) následky.

Každý z diskutujících měl možnost reagovat na pokládané otázky tak, jak uznal za vhodné - jednoslovně, rozvitě, nebo žádným způsobem. Při analýze jsme sledovali i to, jak aktivní byli naši participanti při odpovídání na otázky, jak často rozvíjeli své výpovědi, a zda tak činili sami od sebe, či až po předchozí výzvě. Přitom až 
na diskusní skupinu, jejímiž účastníky byli studenti v hodinách nepř́liš aktivní, jsme studenty o dodatečný komentář nežádali, nebot' to nebylo nutné: studenti doplňovali své výpovědi sami od sebe.

\subsection{2}

\section{Interpretace výzkumných zjištění a dílčí komentáře ve výzkumu self-efficacy $v$ adaptační etapě studia}

Výzkumné šetření mezi ranými vysokoškoláky přineslo mnoho konkrétních dat a jejich pozdějších analýz. Přispěly $\mathrm{k}$ tomu nejen dialogy ve zmiňovaných ohniskových skupinách, ale také interakce v seminářích pedagogické propedeutiky, ve kterých výzkumník v roli vyučujícího o konceptu self-efficacy informoval v podobě teoretického učiva, zároveň studenti měli další př́ležitost se seznámit s některými výzkumy SE, diskutovat o jejich přínosu a vyjadřovat postoje k osobně vnímané zdatnosti.

Pro ilustraci uvádíme některé výzkumné otázky a jejich odpovědi, které považujeme bud' za pro naše téma klíčové, nebo zajímavé pohledem zjištěných výsledků. Čerpali jsme z prací diplomanta Marka Linke $(2012,2013,2016)$, který se v longitudinálním záběru problematice self-efficacy věnoval a jehož práce jsme měli př́ležitost spolukoncipovat a vést.

\section{První prríklad výzkumné otázky}

V01A: Jaké měli participanti předchozí pedagogické zkušenosti (např. zkušenosti s vedením zájmových útvarů a jistoty těchto rolí?

Oprávněně jsme se zajímali o pedagogickou zkušenost respondentů, protože jsme předpokládali, že ti z dotazovaných, kteří měli dřívější možnost výchovně pracovat kupříkladu dětmi a mládeží, budou v interakcích prokazovat větší komunikační jistotu, budou mít větší sebevědomí a více důvodů popisovat své úspěchy (nebo selhání) a hledat jejich příčiny. Náš předpoklad vychází ze samotného konceptu self-efficacy, protože podle Bandury (1977) je jedním z faktorů, který self-efficacy nejvíce ovlivňuje, vlastní zkušenost s danou činností.

\section{Výsledkový komentář}

Šetření prokázalo široký rozptyl zkušeností, které měli respondenti s nějakou podobou předchozí pedagogicko-výchovnou zkušeností. Pohledem konkrétních činností jsme zjistili, že téměř dvě třetiny zpovídaných osob mělo již př́ležitost být $\mathrm{v}$ roli učitele-vychovatele, a to $\mathrm{v}$ těchto příležitostech: lektoři (přírodovědných, hudebních a výtvarných aktivit), trenéři (sportovních činností), vedoucí zájmových 
útvarů (v Domech dětí a mládeže a letních táborech), vyučující při doučování dětí a mládeže (pravidelně dohodnutá setkání), vyučující při neformálním doučování (spontánní příležitosti k výuce v rodině nebo druhých spolužáků).

Mezi studenty s předchozí praxí lze vymezit skupinu těch, kteří pro svou praxi museli absolvovat určitý kurz nebo školení (např. pro možnost vedení skautského oddílu, práce v Domu dětí a mládeže, apod.). Týkalo se to $25 \%$ studentů zúčastnivších se diskuse v ohniskové skupině. Každý z těchto studentů měl navíc zkušenost s pedagogickou praxí v délce alespoň 3 roky. Je zajímavé, že v každé uskutečněné ohniskové skupině se objevil alespoň jeden takový student nebo studentka.

\begin{tabular}{|c|c|c|c|c|}
\hline \multicolumn{5}{|c|}{ Participantky ženy } \\
\hline $\begin{array}{l}\text { Oblast pedago- } \\
\text { gické praxe }\end{array}$ & $\begin{array}{c}\text { Lektor/vedoucí } \\
\text { (s kurzem) }\end{array}$ & $\begin{array}{l}\text { Lektor/vedoucí } \\
\text { (bez kurzu) }\end{array}$ & Doučování & Bez praxe \\
\hline Počet studentek & 4 & 1 & 1 & 2 \\
\hline $\begin{array}{l}\text { Studovaná } \\
\text { aprobace (obory) }\end{array}$ & $\begin{array}{l}\text { RJ, EV, ČJ, DE, Bi, } \\
\text { Ch, VV, ZSV }\end{array}$ & RJ, EV & $\mathrm{AJ}, \mathrm{RJ}$ & AJ, ČJ, M, VV \\
\hline \multicolumn{5}{|c|}{ Participanti muži } \\
\hline $\begin{array}{l}\text { Typ pedagogické } \\
\text { praxe }\end{array}$ & $\begin{array}{l}\text { Lektor/vedoucí } \\
\text { (s kurzem) }\end{array}$ & $\begin{array}{c}\text { Lektor/vedoucí } \\
\text { (bez kurzu) }\end{array}$ & Doučování & Bez praxe \\
\hline Počet studentů & 0 & 1 & 3 & 1 \\
\hline $\begin{array}{l}\text { Studovaná } \\
\text { aprobace (obory) }\end{array}$ & & TV, IN & $\begin{array}{l}\text { AJ, ZSV, M, FY, } \\
\text { VV, TV }\end{array}$ & AJ, IN \\
\hline \multicolumn{5}{|c|}{$\begin{array}{l}\text { Pozn. RJ - ruský jazyk, EV - etika, ČJ - český jazyk, DE - dějepis, BI - biologie, Ch - chemie, VV - vý- } \\
\text { tvarná tvorba, ZSV - základy společenských věd, AJ - anglický jazyk, M - matematika, IN - informatika } \\
\text { a výpočetní technika, TV - tělesná výchova, FY - fyzika }\end{array}$} \\
\hline
\end{tabular}

Tab. 7.6: Oblast praxe participantů a studované obory podle pohlaví (Linke, 2014, s. 9)

Předpokládali jsme, že zejména studenti, kteří absolvovali nějaké školení pro výkon pedagogické praxe, budou mezi všemi ostatními vykazovat nejvyšší míru self-efficacy. Analýza nahrávek však tento předpoklad nepotvrdila: $v$ diskusích směřovala ke studentům otázka, nakolik se cítí jisti, že by obstáli, pokud by byli v současnosti postaveni do situace, kde by měli plnohodnotně převzít roli vyučujících na základní nebo střední škole. Všichni respondenti již s konkrétní pedagogickou praxí (a zároveň absolventi kvalifikačních kurzů nebo školení) odpovídali, že se jistě necítí a že by pro ně bylo obtížné tuto roli přijmout. Jako důvody uváděli nedostatečné znalosti jak ve studovaných oborech, tak pedagogicko-psychologickém základu a v neposlední řadě vnímali svůj nízký věk jako překážku k získání potřebné autority. 
Pokud tuto skupinu srovnáme s ostatními, kteří mají určitou zkušenost například s doučováním, docházíme k zajímavému zjištění, že mezi těmito studenty se již vyskytli dvě třetiny těch, kteří by podle jejich názoru roli učitele zvládli. Uváděli, že by se opírali o již nabyté zkušenosti a úspěšné situace z předchozího období.

Konstatujeme, že proti očekávání se u skupiny studentů s pedagogickou praxí a navazujícími kvalifikačními kurzy projevila menší míra self-efficacy než u jejich vrstevníků, kteří také měli potřebné pedagogické zkušenosti, avšak bez další prohlubující se připravenosti.

Logicky vyvstává otázka, proč tomu tak je a co stojí za tímto zjištěním? Jde o skutečnost, že studenti, jež mají za sebou další kvalifikační kurzy, už mají schopnost realističtějšího pohledu na pedagogickou činnost $v$ její spletitosti a náročnosti? Jsou k sobě více nároční s ohledem na vnímání svých schopností a dovedností - obecně dispozic pro autentické pedagogické působení? Cítí potřebu se dále vzdělávat, aby byli kompetentní, a to jak zvnitřněním těchto kompetencí a i „prostým faktem“, že budou za čas oficiálními absolventy pedagogických studií a "de jure povoláni“ k učitelskému povolání? 0 těchto a dalších důvodech můžeme spekulovat, nicméně pravdivé důvody budou nejen mezi výše uvedenými, přidají se k nim také osobité životní cesty a individualita zpovídaných studentů.

Druhou skupinu respondentů tvořili ti, kteří žádnou předchozí pedagogickou průpravou neprošli. Zařadili jsme mezi ně i ty, kteří měli zkušenosti s tzv. spontánním doučováním. Byli v situacích, kdy doučovali členy rodiny nebo známé, a to většinou bez cílené předchozí přípravy a bez uvědomělé zodpovědnosti za „žáky“ a jejich výsledky.

Tuto skupinu studentů tvořila asi jedna třetina ze všech respondentů. Procesuálně i tito studenti odpovídali na stejné otázky jako ti s pedagogickou praxí a měli stejnou možnost zapojit se do vícesměrné diskuse. Je pochopitelné, že zatímco studenti s praxí se opírali hlavně o své vlastní zážitky a zkušenosti, studenti bez praxe tuto možnost neměli a ve výpovědích se orientovali především na vzpomínky na střední školu, popisovali její prostředí, sociální zkušenosti a komentovali pedagogickou zdatnost svých bývalých učitelů.

Předpokládali jsme, že self-efficacy studentů bez praxe bude mít obecně nižší hodnoty než u studentů s praxí. Analy tické výsledky však jednoznačnost předpokladu nepotvrdily. Větší část respondentů bez pedagogické praxe se cítila méně osobně zdatná, zbývající třetina pak verbálně prokazovala vysokou míru SE, což dokládali postojem, že by $\mathrm{v}$ pedagogickém prostředí v roli učitele-vychovatele zvládali a obstáli by v ní.

Student Martin odpověděl doslova: „To bych potřeboval hodně vysokou míru self-efficacy, protože to bych byl vržen do kýble s mlékem a musel bych ho utlouct na máslo. Ale já myslím, že by to bylo zajímavé, já bych to třeba i zkusil“. 
Z porovnání výsledků z obou skupin je patrné, že samotná předchozí zkušenost s pedagogickou praxí není klíčovým indikátorem míry self-efficacy u jednotlivých začínajících studentů učitelství. Podle našeho názoru může být důvodem několik faktorů: za prvé již zmiňovaná skutečnost, že studenti s praxí a absolvovaným kurzem mají schopnost vidět „aktivní učitelování“ do větší hloubky, dokáží si představit problémy, se kterými by se mohli v roli pedagoga setkat, a proto se zatím necítí jistí, že by popisovanou situaci zvládli. Můžeme hovořit o předprofesním respektu k roli, do které ještě nedozráli. Naproti tomu studentům bez jakékoliv výchovné praxe tento respekt a reálný pohled úplně chybí a jejich vyšší míra self-efficacy může pramenit z toho, že respondenti nevidí téma v mnoha vztazích a konkrétních problémech, které by museli řešit. $\mathrm{Z}$ diskuse vyplynulo, že zatím nemají obavu $\mathrm{z}$ „něčeho nového, zatím neznámého“, což by v opačném případě mohlo míru self-efficacy realisticky snížit.

Druhým důvodem, proč míra osobně vnímané zdatnosti byla u jednotlivých skupin respondentů různá, je spojena s mírou individuálních psychických vlastností respondentů a jejich vývojem. Připomeňme alespoň některé z nich, které mají na vnímanou osobní zdatnost př́mý nebo zprostřed kovaný vliv. Významným individuálně-psychickým aspektem je vůle a způsob překonávání překážek. Míra obecné self-efficacy studenta může být zásadněji ovlivněna tím, jaké má student dlouhodobé zkušenosti s řešením nahodilých, neočekávaných či neznámých situací. Je pro určitého studenta obvyklé, že mobilizuje psychické síly k jejich zvládnutí, nebo spíše s demonstrovanou pasivitou vyčkává, až se situace „sama“ vyřeší, nebo se spoléhá na prostředí, které pomůže? Je nová a neznámá situace onou pověstnou „výzvou“ a důvodem k aktivizaci všech momentálních sil? Ukazuje se, že znalost sebe sama (na základě osobní zkušenosti) hraje podstatnou roli v ujasnění míry osobní zdatnosti v budoucích situacích.

Shrnutí: Náš předpoklad, že míra self-efficacy začínajících studentů učitelství (vztažená k učitelské profesi) je ovlivněna hlavně jejich dosavadními pedagogickými zkušenostmi, se při výzkumu nepotvrdila.

\section{Druhý př́íklad výzkumné otázky}

V01E: jaké měli (či mají) pedagogicko-výchovné vzory a nakolik se s nimi ztotožňují? V klasické pedeutologické literatuře najdeme dost informací o tom, jakými kompetencemi by měl být vybaven učitel-profesionál a s jakými vlastnostmi ho spojujeme. Obvykle se hovoří o těchto složkách způsobilosti: odborně vědní, pedagogicko-psychologické, psycho-didaktické, sociálně komunikativní, diagnostické a sebereflexivní, manažerské a konzultativní (volně podle Průchy, Walterové a Mareše, 2001). Zajímalo nás, nakolik respondenti ve svých výpovědích tyto kompetence zmiňují, hovoří-li o pedagogických vzorech, nakolik se s nimi ztotožňují a uvádějí 
na příkladech z jejich dosavadní role žáků a studentů. Pro ilustraci uvádíme také autentické studentské výroky. Dále komentujeme „výskyt“ pedagogických kompetencí z jednoduchého pohledu - nakolik byly časté ve studentských výpovědích.

Naše šetření ukázalo, že v respondentských výpovědích o „učiteli-ideálu“ chyběly zcela zmínky o některých dříve vyjmenovaných pedagogických kompetencích. Respondenti např. vůbec neuvažovali o tom, že učitel má provádět konzultační činnost směrem k rodičům, představitelům regionu. Přitom poradenství - zejména k rodičům žáků - je častou s profesí učitele spojenou činností. Obdobně jsme nezaznamenali názory o schopnosti pedagoga diagnostikovat osobnost žáků a provádět sebepoznávání a sebereflektovat své jednání, aby z jeho výsledků vzešlo jeho upravené jednání a chování. Považujeme to za logické, protože o pedagogické diagnostice a reflexi se začínající studenti učitelských oborů ještě v teoretické výuce „neučili“ a navíc tyto kompetence si především uvědomuje pedagog s určitými zkušenostmi s výukou, ve které poznává druhé i sebe sama.

Které učitelské kompetence respondenti v ohniskových skupinách sice zmínili, nicméně byly málo četné? Zaznamenali jsme mimo jiné epizodické výpovědi o učitelově oborově-vědní kompetenci, resp. o názoru, že pedagog by měl být především znalec svého oboru a měl by důstojně danou vědu reprezentovat. Za nemnoho výroků tohoto typu uvádíme:

Nela: Taky u tý matiky je hodně důležitej ten základ, když chce někdo studovat matiku, musí mít dobrý základy...

Také ojediněle se studenti zmiňovali o tom, že učitel „funguje“ i jako manažer, který organizuje i mimoškolní činnost a propojuje volnočasové aktivity s přímou pedagogickou činností. Opět uvádíme jeden z mála výroků, který se manažerské kompetence týkal:

Zdena: měla jsem matikářku třídní, co byla vzor. Věnovala se nám ve svém volném čase, dělala spoustu věcí navíc, aniž by musela, spousta pokusủ a věcí navíc, abychom pochopili látku, odpoledne s námi šla ven a ukazovala v praxi, díky tomu mě matika baví...

Poněkud více výroků jsme zaznamenali, když studenti hovořili o tom, jak má pedagog vyučovat, jaké má mít psycho-didaktické přístupy a jak má pracovat s učivem. Osobně považujeme tuto kompetenci za jednu z těch klíčových, které profilují každého člověka v roli učitele. Dejme slovo autentickým výpovědím:

Nela: My jsme měli na základce učitele, kterej vždycky ze všeho udělal srandu. On měl takovej přístup. My jsme ho měli na zeměpis a on ke všemu udělal př́iběh. My jsme se smáli a já jsem se na to třeba vůbec neučila, protože to bylo takový vtipný hlášky a všichni jsme si to pamatovali a měli za jedna. Musí zaujmout.... 
Mirek: matika není jen věda, ale dá se aplikovat v př́rodě... kdybychom šli ven a koukaly se na domy a spočítali si jak dlouho bude ze střechy padat kamínek...

Klárka: učitel by měl být objektivní a zohlednit, když je lehčí a těžší varianta písemek...

Dostáváme se k těm výrokům, které pohledem dílčích kompetencí byly nejčastější a nejvíce vypovídaly o dané způsobilosti. Do této skupiny patřily výpovědi o pedagogicko-psychologických dispozicích učitelů. Část z nich pojmenovávala osobnostní vlastnosti učitelů, část byla o podmínkách toho, aby učitel byl úspěšný a rozuměl osobnosti svých žáků. Pro ilustraci uvádíme autentické výroky studentů: Markéta: učitel musí být autorita... vyučování by mělo být založeno na dobrým přístupu žák-učitel...

Terka: maminka byla učitelka, která mě učila, byla celá vzorem jako učitel. Ukázala, jak se $k$ dětem chovat, jak si získat respekt. Nedat se. Jakmile tě jeden dostane, už to jede... Petr: ...nadšení, pozitivní přístup k lidem. Pamatuju si ho i ze střední. On je strašně pozitivní. Je schopný z čehokoliv, z té výtvarky udělat vše kladný - že je to dobře, že to tak má být...

Kuba: Já mám víc vzorů, at’ už ze základky, nebo i z střední školy... Obzvlášt' zaujala učitelka na češtinu na základní škole; její př́stup: získá si respekt, když je potřeba, přitvrdí, ale jinak byla úplně v pohodě, když někdo přišel a domluvil se v klidu a včas... ten respekt je nejdůležitější co může člověk mít. Pak za ním budou chodit víc než ke třídnímu...

Katka 2: ve výuce a hodnocení se projevují sympatie a antipatie (stejné odpovědi $v$ testech a jiné hodnocení). Je možné se úplně vyhnout? Jsme lidi, takže se asi nejde úplně oprostit, ale učitelé by se měli být schopní oprostit...

Bára: Pro mě je důležitý, aby byl člověk autorita a zároveň, aby byl náš přítel, abychom věděli, že za ním můžeme kdykoliv jít a on nám to nebude pak vracet...

Nejvíce respondentských výpovědí se týkalo sociálně-komunikativní kompetence vyučujících. Rozumíme tomu, protože vyučování je především o komunikaci mezi jeho účastníky a týká se jak učiva, tak sociálních témat, která jsou se životem ve třídě spojena. Časté výroky se týkaly interakce ve třídě - v dobrém i záporném slova smyslu a důsledků, které z toho vzešly. A část respondentské komunikace se týkala péče o sociálně vhodné klima ve třídě. Uved'me některé z výpovědí a dodejme, že většinově měly emotivní charakter:

Markéta: hlavně si myslím, aby ten učitel nebyl třeba až moc př́snej, aby se ty děti nebály zeptat na něco...

Katka 1: měl by se umět vcítit a pochopit. Měl by zvládat kulturní akce, kde se setkávají cizinci s dětmi, kteří se setkávají s dětmi z naší kultury...

Katka 1: měl by se zajímat se nejen o studenty, ale i o studenty jako lidi, o jejich rodiny, volný čas, pomáhá řešit problémy, nesmí to skončit jen vyučovací hodinou... 
Katka 2: Učitel je přítel, vzor, někdo, kdo ukáže cestu kudy dál a přitom učí novým věcem... neměl by sdělovat své rodinné problémy dětem na prvním stupni, já bych to potlačovala, protože děti by to nepochopily. Děti na gymplu by to ale pochopit mohly... Katka 3: měl by respektovat žáky, což je dưležité, aby on sám byl respektován - když zadá pravidlo, musí to plnit on sám, oboustranně rovnocenná komunikace, trpělivost. Osobní problém by neměl negativně přenášet na studenty, může to řešit, ale ne tak, aby si vylíval zlost. Má to říct narovinu a ne tak, že studenti si to odnesou...

Radka: učitel to může říct, pokud je tam vzájemná důvěra. Konkrétní příklad: měli jsme učitelku, kde byly pozitivní vztahy, a ta jednou řekla, že jí není dobře a vzali jsme to líp, než kdyby se opírala o tabuli a bylo vidět, že jí je zle...

Kateřina 1: učitel by neměl být hrubý, zaujatý. Hrubý znamená násilí. Měli jsme učitelku, která vzala studentku, které něco nešlo, za vlasy a máčela jí hlavu pod vodou, aby se jí rozsvítilo. To není vhodné...

Pavla: učitel by měl přistupovat ke každému stejně, at’ už je bílý, nebo černý, jde mu to ve škole lépe, hưře...

Nela: učitel by si měl dokázat udělat srandu sám ze sebe a bylo by vidět, že je člověk jako my. Aby bylo vidět, že je to člověk, kterej má doma rodinu a děti třeba...

Shrnutí: představy o učiteli jako pedagogickém vzoru, byly u respondentů interpretovány velmi různě a osobitě. Vycházely především z konkrétních osobních zkušeností, které většina zpovídaných studenti zobecnila a vyjádřila v polaritě: dobře x špatně. Mnohé z nich byly emotivně podbarvené a dávaly tušit, s jakými postoji se k popisované učitelské vlastnosti nebo situaci stavěli. Zajímali jsme se také o to, jak přímo nebo skrytě respondenti hovořili o pedagogických kompetencích učitelů a které měly podle nich pro popis učitele coby vzoru význam. Zjistili jsme, že nejvíce si studenti všímali pedagogicko-psychologických vlastností vyučujících a zejména pak jejich sociálně komunikativních dispozic. Respondenti stáli o to, aby vyučování bylo dialogické, vycházelo z dobrých vztahů mezi jeho účastníky, kteří se záměrně starají o vhodné sociálně výukové klima. Konečně: pohledem osobně vnímané zdatnosti se jen některé výpovědi dostaly do tvaru: „já bych na místě učitele..." - proto většina výpovědí měla spíše normativní charakter: „učitel by měl“...

\section{Třetí příklad výzkumné otázky}

V02: jak jsou začínající studenti schopni pochopit a uchopit koncept self-efficacy? Ve všech ohniskových skupinách jsme koncept self-efficacy stručně představili, seznámili je s podstatou pojmu a dále prostřednictvím odpovědí na čtyři otázky sledovali, jak a do jaké hloubky studenti koncept pochopili. Studentům jsme postupně položili tyto otázky:

V02A: je možné, aby míra self-efficacy učitele ovlivnila self-efficacy jeho studentů? 
VO2B: domnívají se respondenti, že se dá self-efficacy záměrně rozvíjet?

V02C: je reálný předpoklad, že může učitel self-efficacy cíleně rozvíjet u svých studentů?

VO2D: považují respondenti za prospěšné, aby koncept self-efficacy byl představen budoucím učitelům v prvním ročníku studia v rámci pedagogických disciplín?

\section{Odpovědi respondentů na čtyři otázky týkající se self-efficacy}

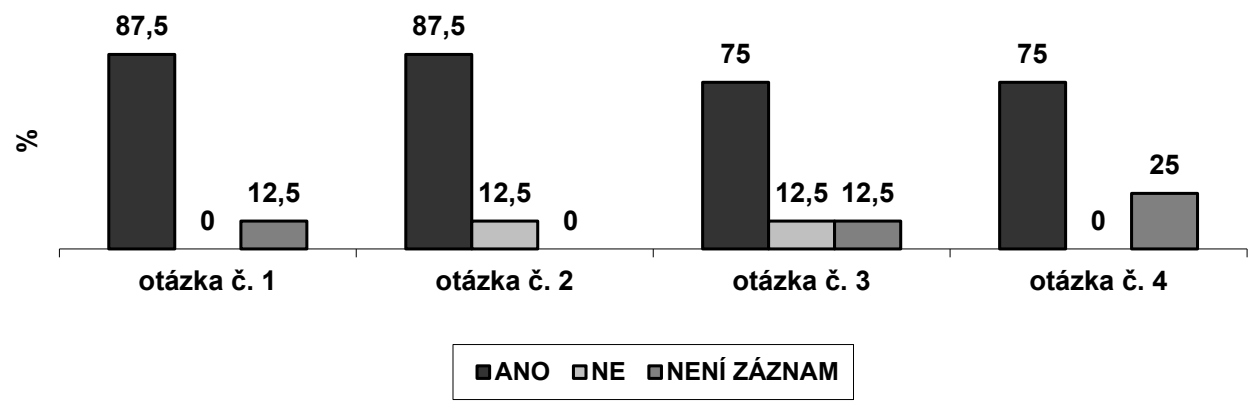

Graf 1: Odpovědi začínajících studentů učitelství na čtyři otázky týkající se self-efficacy (Linke, 2013)

Z grafu č. 1 (resp. ze studentských výpovědí) je zřejmé, že si začínající studenti učitelství většinou uvědomují, že self-efficacy učitele ovlivňuje self-efficacy jeho studentů. Kladně také odpověděli na otázku, zda je možné SE rozvíjet, a že učitel tak může u svých žáků-studentů činit záměrně. I na poslední otázku - zda má smysl se o Bandurově konceptu osobně vnímané zdatnosti něco v učitelské přípravě dozvědět, odpověděli respondenti kladně a vidí možnost, aby se tak stalo v některých pedagogicko-psychologických disciplínách učitelského studia.

Na základě analýzy odpovědí na otázky a jejich komentářů se ukázalo, že studenti mohou mít k pojmu self-efficacy různý vztah, který lze vyjádřit v těchto čtyřech úrovních: 


\begin{tabular}{|c|c|}
\hline Úroveň & Popis úrovně \\
\hline $\begin{array}{l}\text { Úroveň 1: porozumění } \\
\text { definici }\end{array}$ & $\begin{array}{l}\text { student porozuměl pojmu self-efficacy na úrovni } \\
\text { obsahového významu }\end{array}$ \\
\hline $\begin{array}{l}\text { Úroveň 2: interiorizace } \\
\text { vzhledem k vlastní osobě }\end{array}$ & $\begin{array}{l}\text { student porozuměl obsahu pojmu self-efficacy, } \\
\text { uvědomuje si jeho význam pro sebe a je schopný } \\
\text { se self-efficacy pracovat vzhledem k vlastní } \\
\text { osobě }\end{array}$ \\
\hline $\begin{array}{l}\text { Úroveň 3: interiorizace } \\
\text { vzhledem k sociálnímu } \\
\text { okolí }\end{array}$ & $\begin{array}{l}\text { student porozuměl obsahu pojmu self-efficacy } \\
\text { a uvědomuje si význam nejen pro sebe ale i pro } \\
\text { ostatní (žáci, studenti, kolegové), a je schopný se } \\
\text { self-efficacy pracovat vzhledem k druhým lidem }\end{array}$ \\
\hline $\begin{array}{l}\text { Úroveň 4: interiorizace- } \\
\text { intervence }\end{array}$ & $\begin{array}{l}\text { student porozuměl obsahu pojmu self-efficacy, } \\
\text { uvědomuje si jeho význam pro sebe a pro } \\
\text { ostatní, a je schopen aktivní intervence s cílem, } \\
\text { aby druhý člověk vnitřně porozumél pojmu self- } \\
\text { efficacy (student je schopen druhého člověka } \\
\text { dovést na úroveň } 2 \text { až 3) }\end{array}$ \\
\hline
\end{tabular}

Tab. 7.7: Úrovně pochopení a uchopení konceptu self-efficacy začínajícími studenty učitelství (Linke, 2013)

Každá úroveň vyjadřuje určitou hloubku pochopení konceptu self-efficacy, míru schopnosti vnímat vlivy formující self-efficacy jedince, a schopnost interakce s těmito vlivy. $\mathrm{Z}$ analýzy diskuzí $\mathrm{v}$ ohniskových skupinách vyplynulo, že každý $\mathrm{z}$ respondentů byl schopný pochopit koncept self-efficacy minimálně na úrovni 2 : interiorizace vzhledem k vlastní osobě. Každý z respondentů byl tak schopen nejen pochopit obsah pojmu self-efficacy, ale také spojit tento teoretický pojem s vlastními zážitky a zkušenostmi, a nalézt význam osobně vnímané zdatnosti pro sebe v rámci svého současného a budoucího studia. Pro ilustraci jsme vybrali několik zajímavých odpovědí k některým otázkám.

Petr (odpověd' na otázku č. 3): „Podle mě určitě, hlavně a zásadně tím, že učitel žáky motivuje k tomu, že je oukej udělat chybu. Děti se nesmějí bát toho, že je něco špatně." Jana (odpovídá na otázku č. 4): „Myslím si, že je důležité, abychom našli nějakou důvěru sami v sebe třeba formou takovýchto diskuzí - aby byl někdo, kdo by nám třeba směřoval myšlenky způsobem, abychom sami sebe našli. Protože spousta lidí v našem věku hledá nějaké to své já, které by později bylo schopné někam někoho dovést." Petr (odpovídá na stejnou otázku): „Já si myslím, že všechno, co jsme tady rozebírali, nějak podvědomě i víme, ale nemáme to zastřešené nějakým pojmem. Je podle 
mě dobré to nějak zastřešit, a je podle mě fajn ta myšlenka, že by se s tím studenti seznamovali už v prváku."

\section{Shrnutí:}

Z výsledků analýzy výpovědí respondentů vyplývá, že studenti prvního ročníku učitelství jsou schopni pochopit koncept self-efficacy minimálně na druhé zmiňované úrovni. Jsme přesvědčeni, že by bylo pro učitelskou profesionalizaci užitečné, kdyby se již začínající studenti učitelství „plánovitě“ seznamovali s konceptem self-efficacy už v prvních pedagogicko-psychologických disciplínách. Získali by tak - kromě rozšíření znalostí - vhodný nástroj k dalšímu sebepoznávání, včetně „elaborace“ se svým rozvojem. Rozvíjení osobní zdatnosti by tak dostalo praktický smysl a mohlo by být dále rozvíjeno ve vhodně „nastavených“ předmětech - včetně pedagogických praxí.

\subsection{3}

\section{Závěrečné ohlédnutí}

Je mnohokrát opakovaným poznáním, že nově vznikající teorie v oblasti sociálních věd žijí svým vlastním životem; na jedné straně vyvolávají další teoretické modifikace a dochází k prohlubování tématu, na straně druhé mají také odezvu mezi badateli, kteří se snaží posunout poznání o empirická šetření a jejich efekty. Nejinak je tomu i v případě Bandurova konceptu self-efficacy, který od 70. let minulého století prošel nejednoduchým vývojem, ke kterému přispěly různé vědní obory a badatelé z různých zemí.

Zmiňovaná socio-kognitivní teorie staví člověka do aktivní role, ve které se snaží poznat své potenciality a spěje k přesvědčení, že ví, co a jak bude konat a že dospěje k vytyčenému cíli. Hovoříme o obecné self-efficacy, která postupem času našla své mnohé aplikace také v prostředí výchovy a vzdělávání.

Ukazuje se, že osobně vnímaná zdatnost v pedagogických souvislostech byla a je častým předmětem zájmu teoretiků i výzkumníků. Rešerše bibliografie by potvrdila, že zájem se soustředí především na rozvoj poznatků o self-efficacy v autentickém prostředí základní nebo střední školy a dílem se zajímá o vyučujícího, dílem pak o žáky a jejich osobně vnímanou zdatnost.

Mnohem méně se ví, jak k Bandurovu konceptu přistoupit v podmínkách vysokoškolské výuky (v našem případě u budoucích učitelů), kteří po svém řeší otázku individuální zdatnosti a úspěšnosti v budoucích pedagogických situacích na základě dosavadních zkušeností. Tak jako učitel v činné službě prochází vývojovými etapami, obdobně i vysokoškoláci prochází různými fázemi své profesionalizace. $V$ jejich 
jednotlivých etapách bude přístup k self-efficacy různý a budou se na něm podílet jak osobnostní zrání, zkušenosti z mezilidské interakce, tak získávané teoretické poznatky, především však praktická příležitost „stávat se učitelem“.

Náš zájem se soustředil na specifickou skupinu začínajících studentů učitelských oborů, u které nás zajímalo, jak o své osobní zdatnosti uvažují a nakolik je pro ně toto téma srozumitelné a „aplikovatelné“ na vlastní osobě. Proč právě tato skupina budoucích učitelů je zajímavá? Na tuto otázku jsme odpověděli již v kapitole v prvním díle monografie z roku 2012. Začínající studenti mají zvláštní pozici mezi vysokoškoláky: po formální stránce jsou homogenní skupinou na startu učitelské profesionalizace a čeká je „unifikovaná“ cesta k absolutoriu. Ve skutečnosti jde o velmi různorodou skupinu mladých lidí, kteří mají individuálně různé osudy, vykazují specifické osobnostní a sociální vlastnosti, mají různou zkušenost z interakce se svým okolím a jejich cesta $\mathrm{k}$ budoucí profesi bývá započata vzájemně nesrovnatelnými zkušenostmi.

Ohlédněme se za končící kapitolou. Považujeme za př́nosné, že jsme toto pro pedeutologii „bílé místo“ obohatili o možnou podobu proměn člověka v roli studenta učitelství a načrtli, jakými cestami se během vysokoškolského studia může ubírat. Pro nás významně jsme popsali, že začínajícího studenta učitelství v počátku čeká tzv. adaptační etapa profesionalizace, charakteristická mnoha změnami a proměnami vztahu nejen k sobě samému, ale především k novému prostředí a jeho atributům.

V jiném úhlu pohledu se vynořila otázka: kdo jsou začínající budoucí učitelé, jak o své osobně vnímané zdatnosti uvažují a nakolik ji považují za neodmyslitelnou součást pedagogického prostředí a jejích aktérů. Ukázalo se, že výzkumných aktivit, které by vedly alespoň k dílčím odpovědím, není mnoho a masivnější zájem chybí. Proto přišlo rozhodnutí obohatit dosavadní výzkumy o naše šetření, založené na kvalitativní metodologii, přesněji na analýzách plynoucích $\mathrm{z}$ dat, která vznikla z interview v ohniskových skupinách.

Přišla nám blízká mimo jiné tím, že principem vychází z vícesměrného dialogu jejích účastníků, kteří komentují své postoje k jednotnému tématu. Upozornili jsme na to, že má-li dojít až k auto-dialogickému stádiu rozhovorů (přesněji k synergickému efektu), je třeba, aby garanci nad průběhem dění ve focus group převzal kvalifikovaný moderátor, vybavený nejen dobrou přípravou, ale také schopností adekvátně reagovat na spontánní projevy účastníků diskuse. Procesuální stránku interview v ohniskové skupině jsme vyjádřili v chronologickém schématu a popsali činnost účastníků focus group v jejích jednotlivých fázích. Potud metodologická příprava na konkrétní výzkumné šetření.

Závěrečná kapitola 7.2 tvoří informace o výzkumném designu našeho šetření, dílčích výzkumných otázkách a nálezech. Zajímali jsme se zejména o osobně vnímanou zdatnost začínajících studentů učitelských oborů na základě jejich zkušenosti 
se sebou samými, a to v klíčových událostech jejich života (úspěšností a prožitky na střední škole, motivy volby vysoké školy, adaptací v novém akademickém prostředí, ztotožnění se s pedagogickými vzory apod.). Po teoretické „injekci“ o tom, co je koncept self-efficacy a jaké má principy, nás zajímalo, nakolik této teorii porozuměli a nakolik jsou schopni vidět její užitek ve výchovně-vzdělávací praxi.

Které klíčové poznatky šetření v ohniskových skupinách přineslo? Nehomogenitu studentského vzorku potvrdily nálezy o jejich různé předchozí pedagogické zkušenosti; na jedné straně jsme se setkali s respondenty, kteří byli aktivní při vedení volnočasových aktivit dětí a mládeže a někteří z nich ještě měli za sebou účast na kvalifikačních kurzech. Jen menší část respondentů neměla „na čem stavět" a jejich pedagogické zkušenosti byly minimální. Paradoxně právě tato skupina studentů vykazovala vyšší míru SE oproti vrstevníkům s pedagogickou praxí.

Diskusemi v ohniskových skupinách se ukázalo, že studenti jsou schopni o konceptu self-efficacy uvažovat ve 4 úrovních: porozumění definici, interiorizaci vzhledem k vlastní osobě, interiorizaci vhledem k sociálnímu okolí a konečně interiorizaci a s následnou intervencí ve prospěch rozvoje SE. V respondentských skupinách převládaly výpovědi potvrzující zejména druhou zmiňovanou úroveň.

Ve studentských postojích převládal názor, že je možné, aby míra self-efficacy učitele ovlivnila self-efficacy jeho studentů. Obdobně kladně přijali myšlenku, že je možné SE cíleně rozvíjet, a to jak na straně pedagoga, tak žáků-studentů.

Jedna z posledních otázek k dotazovaným studentům zněla: myslíte si, že by bylo pro studenty prospěšné představit koncept self-efficacy v prvním ročníku studia $\mathrm{v}$ rámci některé z pedagogických disciplín? Nepřekvapilo masivní kladné stanovisko - naprostá většina spatřovala v novém poznání myšlenkové obohacení, které mělo dopad na každého z nich.

S uspokojením se domníváme, že jsme k tomu přispěli i my, méně obvyklým přístupem k výzkumné činnosti. Výzkumník se totiž studentům představil současně jako vyučující jedné z pedagogických disciplín a měl možnost jak v přednáškách, tak $v$ semináŕích o tématice self-efficacy hovořit, studenty vést $\mathrm{k}$ dílčím diskusím a uvažování o bližších i vzdálenějších souvislostech. Jsme přesvědčeni, že jsme takto obohatili dosavadní výukové kurikulum a podíleli se na jeho aktualizaci. Vedle teoretického poznání si studenti rozšíríli vědomosti o nové metodologické nástroje $\mathrm{v}$ pedagogickém výzkumu a zároveň měli možnost být aktivní součástí poznávaného jevu. Tím, že byla seminární výuka založena na vzájemné interakci, předávání osobních postojů a vyjasňování stanovisek, efektem bylo větší vzájemné poznání studentů mezi sebou, což vedlo k vytváření neformálních komunitních vztahů a v konečném důsledku i k urychlení adaptace na vysokoškolské prostředí.

Hovoříme-li o obsahu kapitoly a vztahu k přípravě začínajících budoucích učitelů, nemůžeme zamlčet jeden ze záměrů, se kterým kapitola od počátku vznikala. 
Záměrně jsme jí dali podobu studijní opory, tedy textu, ze kterého je možné ve výuce čerpat a ze kterého je možné studovat. Kdyby se naplnilo byt' jen toto poslání, pak může oprávněně zavládnout autorská spokojenost s dílem, které má své zaujaté čtenáře. 



\section{ZÁVĚR}

Monografie s názvem „Self efficacy v edukčních souvislostech II“ navazuje na monografii I (Wiegerová, et. al., 2012). Sedm kapitol tohoto nového díla popisuje pole zkoumání self efficacy v širokých teoretických, historických a empirických perspektivách a ukazuje podstatu vnímané vlastní zdatnosti, její definice a dimenze. Autoři v monografii sumarizují rozsah odborné práce v oblasti self efficacy, předkládají přehled klíčových zjištění a vysvětlují různé přístupy k vyšetřování tohoto konceptu.

Úvodní první kapitola poskytuje prostřednictvím teoretického a historického rámce pohled na self efficacy přes jeho vznik a vývoj, jak jej vypracoval Albert Bandura v rámci své sociokognitivní teorie učení. Jsou v ní vysvětleny i další pojmy, jako je aktérství, sebepojetí a místo kontroly, které souvisejí s vnímanou vlastní zdatností, tak aby čtenáři získali komplexní zobrazení teorie self efficacy. První kapitola slouží pro základní orientaci a určena především pro ty, kteří se orientují $\mathrm{v}$ teorii self efficacy, stejně jako pro nováčky v oborovém zaméření pedeutologie.

Zatímco první kapitola přináší teoretický pohled na koncept self efficacy, kapitola 2 přenáší vnímanou vlastní zdatnost do vzdělávacího kontextu. Popisuje self efficacy učitelů, ředitelů škol a žáků prostřednictvím analytického přehledu empirických studií prezentovaných v mezinárodní perspektivě. Studie a jejich závěry ukazují na sílu vlastní efektivity ovlivňovat dění ve školách s odlišnou akademickou kulturou. Kapitola je doplněna o přehled kvantitativních a kvalitativních metod, využívaných při výzkumech self efficacy ve školním kontextu.

Kapitola 3 nastiňuje vývoj posledního desetiletí výzkumu self efficacy v posledním desetiletí. Je $\mathrm{v}$ ní předložen přehled literárních pramenů a metaanalýz publikovaných v mezinárodních časopisech. 
Doplňkově k tomu je kapitola 4 orientovaná na přehled studií o self efficacy učitelů v České republice.

Protože vysokoškolské vzdělávání je silným zdrojem sledování self efficacy budoucích učitelů, poskytuje kapitola 5 živý pohled na etapy a posloupnosti získávání odborných znalostí studenty vysokých škol. Mladý člověk vstupuje do přípravy ve vysokoškolském vzdělávání, postupuje ve svých fázích a končí jako absolvent schopný autonomní výuky ve školách.

Kapitola 6 představuje podrobný popis kvantitativních a kvalitativních přístupů ke zkoumání self efficacy učitelů a žáků. Kvantitativní část se zabývá postavením teorie v kvantitativním výzkumu, induktivními a deduktivními strategiemi při konstrukci výzkumného nástroje a formátem položek dotazníku. Kvalitativní část představuje sílu uplatnění rozhovoru s cílovou skupinou a popisuje jeho strategie.

Příkladem kvantitativních a kvalitativních přístupů ke zkoumání self efficacy jsou dvě studie in extenso (kapitola 7). Nejprve je představena konstrukce a validace dotazníku pro měření vlastní efektivity budoucích učitelů mateŕských škol SEPRES spolu s popisnými údaji ze dvou českých univerzit. Druhá studie je věnována výzkumu budocoucích učitelů různych aprobačních zaměření prostřednictvým skupinového rozhovoru se skupinou studentů za účelem posouzení rozsahu a hloubky jejich znalostí o konceptuself efficacy.

Snahou autorů monografie bylo shrnout teorii, historii, metodologii vázanou na zkoumání konceptu self efficacy doma i v zahraničí. Výsledky výzkumu nazančují jak významnou oblastí zkoumání se tento koncept v poslendích letech stává. Doufáme tedy, že čtenáři přinese nejen nové poznatky, ale snad i inspiraci. 


\section{SUMMARY}

The monograph entitled "Self-efficacy in the Educational Context II" is a follow-up book to the volume I (Wiegerová, et. al., 2012). Seven chapters of this new volume describe the field of self-efficacy in broad theoretical, historical and empirical perspectives, showing the nature of self- efficacy, its definitions, and the dimensions it frames. The book also summarizes the scope of work in the field of self-efficacy, presents an overview of key findings, and explains varied approaches to investigating this concept.

The initial chapter provides a through theoretical and historical framing of the field of self-efficacy by describing its origin and development, as elaborated by Albert Bandura within his socio-cognitive theory of learning. Other notions, such as human agency, self-concept and locus of control, which are related to self-efficacy, are also explained to bring the reader a comprehensive portrayal of the self- efficacy theory. This chapter serves as a foundational introduction for those who are well-versed in the self-efficacy theory as well as to newcomers to the field.

While this chapter brought a theoretical perspective of self-efficacy, chapter 2 brings to foreground self-efficacy in the educational context, describing self-efficacy of teachers, school principals and pupils in an analytical review of empirical studies conducted in a range of countries. It demonstrates the strength of self-efficacy to affect actions in schools with different academic culture. The chapter is supplemented by an overview of quantitative and qualitative methods of investigating self-efficacy in the school context. Chapter 3 outlines the development of recent decade of the self-efficacy research in a recent decade by presenting literature reviews and meta-analysis published in international journals. Complementary to this is chapter 4 with an overview of studies about self-efficacy of pre-service teachers in the Czech Republic. 
Because the university training is a strong source of pre-service teachers' self-efficacy, chapter 5 provides a keen insight into the stages and sequences of acquisition of professional knowledge by university students in education. The young person enters the teacher training at a higher education, advances through its stages and ends up as a graduate, capable of autonomous teaching in schools.

Chapter 6 presents a detailed description of quantitative and qualitative approaches to investigation of self-efficacy of teachers and pupils. The quantitative section deals with the position of theory in quantitative investigations, with inductive and deductive strategies in constructing a research instrument and the format of questionnaire items. The qualitative section presents the strength of the focus group interview and describes its strategies.

Quantitative and qualitative approaches to the investigation of self-efficacy are exemplified by presenting two studies in extenso (chapter 7). First, the construction and validation of a questionnaire to measure self-efficacy of prospective preschool teachers, SEPRES, is presented together with descriptive data from two Czech universities. Second, a focus group interview with a group of students was performed in order to assess the extent and depth of their knowledge about the concept of self-efficacy.

In sum, the authors' attempt was to comprise self-efficacy theory, history, methodology and research results to make a comprehensive portrayal of this significant field as applied in the educational domain. As such, it is hoped it will not only bring the reader new knowledge but, hopefully, also inspiration. 


\section{LITERATURA}

Abbott, D. H. (2010). Constructing a Creative Self-Efficacy Inventory: A mixed methods inquiry (Doctoral Dissertation). Lincoln: University of Nebraska, $269 \mathrm{s.}$

Aloe, A. M., Amo, L. C., \& Shanahan, M. E. (2014). Classroom management self-efficacy and burnout: A multivariate meta-analysis. Educational Psychology Review, $26,101-126$.

Altan, M. Z., \& Saglamel, H. (2015). Student teaching from the perspectives of cooperating teachers and pupils. Cogent education, 2(1), 1-16. Dostupné z https:// doaj.org/article/a9ef9a1133784d878a7197a5c290ab44.

APA (2014). The road to resilience. Washington: American Psychological Association. Dostupné na: http://www.apa.org/helpcenter/road-resilience.aspx.

Ashton, P., Buhr, D., \& Crocker, L. (1984). Teachers' sense of efficacy: A self- or norm-reference construct? Florida Journal of Educational Research, 26(1) 29-41.

Azar, A. (2010). In-service and pre-service secondary science teachers' self-efficacy beliefs about science teaching. Educational Research and Reviews, 4, 175-188.

Axboe, M.K., Christensenk, S., \& Kofoed, P.E. (2016). Development and validation of a self-efficacy questionnaire (SE-12) measuring the clinical communication skills of health care professionals. BMC Medical Education, 16, 272.

Balaštíková, V., Blatný, M., \& Kohoutek, T. (2004). Aspekty sebepojetí jako determinanty výběru strategií zvládání u adolescentů. Československá psychologie, 48(5), 410-415.

Bandura, A. (1988). Organizational applications of social cognitive theory. Australian Journal of Management, 13, 275-302.

Bandura, A. (1994). Self-efficacy. In V. S. Ramachandran (Ed.), Encyclopedia of human behavior, 4, 71-81. San Diego: Academic Press. 
Bandura, A. (2006). Adolescent development from an agentic perspective. In Pajares, F., Urdan, T. (eds.), Self-efficacy beliefs of adolescents, 1-43. Greenwich, CT: Information Age.

Bandura, A. (1977). Self-efficacy: Toward a unifying theory of behavioral change. Psychological Review, 84(2), 191-215.

Bandura, A. (1982). Self-efficacy mechanism in human agency. American Psychologist. 37(2), 122-147.

Bandura, A. (1986). Social foundations of thought and action: a social cognitive theory. Englewood Cliffs: Prentice-Hall, 617 s.

Bandura, A. (1993). Perceived self-efficacy in cognitive development and functioning. Educational Psychologist, 28(2), 117-148.

Bandura, A. (1994). Self-Efficacy. In Ramachaudran, V.S. (Ed.) Encyclopedia of Human Behavior, Vol. 4. New York: Academic Press, 71-81.

Bandura, A. (1997). Self-efficacy: The exercise of control. New York: Freeman, $604 \mathrm{~s}$. Bandura, A. (1998). Personal and collective efficacy in human adaptation and change. In Adair, J.G., Bélanger, D., Dion, K.L. (Eds.) Advances in psychological science, Vol. 1. Social, personal, and cultural aspects. Hove: Taylor \& Francis, 51-71. Bandura, A. (2000). Exercise of human agency through collective efficacy. Current Directions in Psychological Science, 9(3), 75-78.

Bandura, A. (2001). Social cognitive theory: An agentic perspective. Annual Review of Psychology, 52(1), 1-26.

Bandura, A. (2006 a). Toward a psychology of human agency. Perspectives on Psychological Science, 1(2), 164-180.

Bandura, A. (2006 b). Guide for constructing self-efficacy scales. In Pajares, F., Urdan, T. (Eds.) Self-efficacy beliefs of adolescents. Greenwich: Information Ade Publishing, 307-337.

Barry, N. H., \& Durham, S. (2017). Music in the early childhood curriculum: Qualitative analysis of pre-service teacher's reflective writing. International Journal of Education \& the Arts, 18(16), 1-18. Dostupné na: http://www.ijea.org/v18n16/.

Bergman, Z., Bergman, M., M., \& Thather, A. (2019). Agency and Bandura's model of triadic reciprocal causation: An exploratory mobility study among metrorail commuters in the Western Cape, South Africa. Frontiers in Psychology, 10, Article 411, 1-14.

Boujut, E., Popa-Roch, M., \& Palomares, E. A. et al. (2017). Self-efficacy and burnout in teachers of students with autism spectrum disorder. Research in Autism Spectrum Disorders, 36(1), 8-20.

Brouwers, A. \& Tomic, W. (2003). A test of the factorial validity of the teacher efficacy scale. Research in Education, 69 (May), 67-79. 
Bull, T. (1989). Home-school links: family-oriented or business-oriented? Educational Review, 41(2), 113-119.

Bunnin, N., (ed). (2004). "Lived experience". The Blackwell Dictionary of Western Philosophy. Blackwell Publishing.

Busby, R., Ingram, R., \& Bowron, R. et al. (2012). Teaching elementary children with autism: Addressing teacher challenges and preparation needs. Rural Educator, 33(1), 27-35.

Cakiroglu, J., Cakiroglu, E., \& Boone, W. (2005). Pre-service teacher efficacy beliefs regarding science teaching: A comparison of pre-service teachers in Turkey and the USA. Science Educator, 14(1), 31-40.

Caprara, G. V., Barbaranelli, C., Steca, P., \& Malone, P. S. (2006). Teachers' self-efficacy beliefs as determinants of job satisfaction and students' academic achievement: A study at the school level. Journal of School Psychology, 44(6), 473-490.

Cohen, J. (1988). Statistical power analysis for the behavioral sciences ( $2^{\text {nd }}$ ed.). Hillsdale, NJ: Erlbaum.

Cousins, J. B., \& Walker, C. A. (2000). Predictors of educators' valuing of systematic inquiry in schools. Canadian Journal of Program Evaluation, Special Issue, 25-53.

Čermák, I., \& Urbánek, T. (1997). Vliv self-efficacy na agresi a depresi u dětí. Československá psychologie, 61(3), 193-199.

Del Greco, R., Bernadowski, C., \& Parker, S. (2018). Using illustrations to depict preservice science teachers' self-efficacy: A case study. International Journal of Instruction, 11(2), 75-88.

Demirci, F., \& Ozyurek, S. (2018). Astronomy Teaching Self-Efficacy Belief Scale: The validity and reliability study. Journal of Education and Learning, 7(1), 258-271.

Deeemer, S., \& Minke, K. (1999). An investigation of the factor structure of the Teacher Efficacy Scale. The Journal of Educational Research, 93, 3-10.

Denzine, G., Cooney, J., \& McKenzie, R. (2005). Confirmatory factor analysis of the Teacher Efficacy Scale for prospective teachers. British Journal of Educational Psychology, 75, 689-708.

DeVellis, V. R. (2003). Scale development: Theory and application. Thousand Oaks: SAGE.

Dick, B. (1998). Structured focus groups Dostupné na: http://www.scu.edu.au/ schools/gcm/ar/arp/focus.html.

Dicke, T., Elling, J., Schmeck, A., \& Leutner, D. (2015). Reducing reality shock: The effects of classroom management skills training on beginning teachers. Teaching and Teacher Education, 48, 1-12.

Dytrtová, R., \& Krhutová, M. (2009). Učitel-příprava na profesi. Praha: Grada.

Eden, D. (1996). From self-efficacy to means efficacy: Internal and external sources of general and specific efficacy. Hillsdale, NJ: Lawrence Erlbaum. 
Enochs, L., Smith, P. L., \& Huinker, D. (2000). Establishing factorial validity of the mathematics teaching efficacy beliefs instrument. School Science and Mathematics, 100 (4), 194-202.

Epstein, J. L., \& Salinas, K. L. (2004). Partnering with families and communities. Educational Leadership, 61(8), 12-18.

Erlich, R.J., \& Russ-Eft, D. (2011). Applying Social Cognitive Theory to academic advising to assess student learning outcomes. NACADA Journal, 31(2), 5-15.

Evers, W. J. G., Brouwers, A., \& Tomic, W. (2002). Burnout and self efficacy: Study on teachers' beliefs when implementing an innovative educational system in the Netherlands. British Journal of Educational Psychology, 72, 227-243.

Feldt, R. C. et al. (2011). Measurement adjustment to college: Construct validity of the Student Adaptation to College Questionnaire. Measurement and Evaluation in Counseling and Development, 44(2), 92-04.

Ferjenčík, J. (2000). Úvod do metodologie psychologického výzkumu: jak zkoumat lidskou duši. Praha: Portál.

Flanders, N. A. (1970). Analyzing Teaching Behavior. London: Addison-Wesley.

Fischer, S.M., \& Bilz, L. (2019). Teachers' self-efficacy in bullying interventions and their probability of intervention. Psychology in the Schools, 56, 751-764.

Fox, M. C., Ericsson, K.A., \& Best, R. (2011). Do procedures for verbal reporting of thinking have to be reactive? A meta-analysis and recommendations for best reporting methods. Psychological Bulletin, 137(2), 316-344.

Gau, B.H., \& Hung, Ch.-Ch. (2014). The Self-Efficacy Scale for preschool teachers regarding asthma care: Instrument development and validation. The Journal of School Health, 84(2), 91-98.

Gavora, P. (1996). Výskumné metódy v pedagogike. Bratislava: Univerzita Komenského. Gavora, P. (2006). Sprievodca metodológiou kvalitativního výskumu. Bratislava: Regent.

Gavora, P. (2009). Profesijná zdatnost'vnímaná učitel'om. Adaptácia výskumného nástroja. Pedagogická revue, 61(1-2), 19-37.

Gavora, P. (2010). Slovak pre-service teacher self-efficacy: theoretical and research considerations. The New Educational Review. 21(3), 17-30.

Gavora, P. (2011). Measuring the self-efficacy of in-service teachers in Slovakia. Orbis Scholae, 5(2), 79-94.

Gavora, P. (2012). Koncept self-efficacy. In Wiegerová, A. a kol. (2012) Self Efficacy (osobně vnímaná zdatnost'v edukačných súvislostiach). SPN: Bratislava, 10-16.

Gavora, P. (2012). Skúsenosti so zist'ovaním self-efficacy učitel'a pomocou dotazníka OSTES. Kvalita ve vzdělávání. Sborník příspěvků, XX. výroční konference České asociace pedagogického výzkumu, Praha, 10-12. září 2012. 
Guo, Y., Justice, L. M., Sawyer, B., \& Tompkins, V. (2011). Exploring factors related to preschool teachers' self-efficacy. Teaching and Teacher Education, 27(5), 961-968.

Gebauer, M. M., McElvany, N., \& Bos, W. et al. (2020). Determinants of academic self-efficacy in different socialization contexts: investigating the relationship between students' academic self-efficacy and its sources in different contexts. Social Psychology of Education, 23(2), 339-358.

Geoghegan, N., Geoghegan, D., O’Neill, S., \& White, R. (2004) Pre-service early childhood teachers' self efficacy, teacher preparedness and facilitating children's learning of concepts in multiple contexts. Australian Association for Research in Education.

Gist, M.E. (1989). The influence of training method on self-efficacy and idea generation among managers. Personnel Psychology, 42(4), 787-805.

Gibson, S., \& Dembo, M. H. (1984). Teacher efficacy: A construct validation. Journal of Educational Psychology, 76(4), 569-582.

Glackin, M., \& Hohenstein, J. (2018). Teachers' self-efficacy: progressing qualitative analysis, International Journal of Research \& Method in Education, 41(3), 271-290.

Greger, D. (2011). Jak čeští učitelé hodnotí vlastní efektivitu? Adaptace zahraničního dotazníku. Referát na konferencii ČAPV, Brno.

Guskey, T. R. \& Passaro, P. D. (1994). Teacher e!cacy: A study of construct dimension. American Educational Research Journal, 31, 645-674.

Gore, P. A. (2006). Academic self-efficacy as a predictor of college outcomes: Two incremental validity studies. Journal of Career Assessment, 14, 92-115.

Guo, Y., Justice, L. M., \& Sawyer, B. et al. (2011). Exploring factors related to preschool teachers' self-efficacy. Teaching and Teacher Education, 27(5), 96-968.

Hamill, S. K. (2003). Resilience and self-efficacy: The importance of efficacy beliefs and coping mechanisms in resilient adolescents. Colgate University Journal of the Sciences, 35, 115-146.

Hastings, P. (2012). Early career teachers' self-efficacy for balanced reading instruction, Australian Journal of Teacher Education, 37(6), 55-72.

Haverback, H. R., \& Parault, S. J. (2008) Pre-Service Reading Teacher Efficacy and Tutoring: A Review. Educational Psychology Review, 3, 237-225.

Hebronová, V. (2014). Sebehodnocení a jeho vliv na self-efficacy žáka. Diplomová práce. Brno: PedF MU, 111.

Hejlová, H., Opravilová, E., Uhlířová, J., \& Bravená, N. (2013) Nahlížení do světa dětí. Praha: UK.

Hemphill, J. F. (2003). Interpreting the magnitudes of correlation coefficients. American Psychologist, 58(1), 78-80.

Hendl, J. (1997). Úvod do kvalitativního výzkumu. 1. vyd. Praha: Karolinum. Hendl, J. (2005). Kvalitativní výzkum. Základní metody a aplikace. Praha: Portál. 
Henson, R. K. (2002). From adolescent angst to adulthood: Substantive implications and measurement dilemmas in the development of teacher efficacy research. Educational Psychologist, 37(3), 137-150.

Henson, R. (2001). Teacher self-efficacy: Substantive implications and measurement dilemmas. Paper at the annual meeting of the Educational Research Exchange. January 26, 2001. Texas A\&M University, Texas.

Hofstede, G., \& Hofstede, G. J. (2006). Kultury a organizace. Software lidské mysli. Praha: Linde 335 s.

Horaková-Hoskovcová, S. (2006). Self-efficacy in Preschool Children. Studia Psychologica. 48(2), 175-182.

Hughes, G. (1999). Facilitating the Development of Pre-service Teachers' in a Climate of Reform: Lessons Learned from Mathematics and Assessment Reform. The Journal of Negro Education, 3.

Chan, D. W. (2008) General, collective, and domain-specific teacher self-efficacy among Chinese prospective and in-service teachers in Hong Kong. Teaching and Teacher Education. 4, 1057-1069.

Chang, E.C., Sanna, L., Riley, M. M., Thornburg, A. M.,Zumberg, K. M., \& Edwards, M. C. (2007). Relation between problemsolving styles and psychological adjustment in young adults: Is stress a mediating variable? Personality and Individual Differences, 42(1), 135-144.

Charalambous, Y., Philippiou, G., \& Kyriakides, L. (2004). Tracing the development of preservice teachers' efficacy beliefs during fieldwork. Educational Studies in Mathematics (on-line). Available: www.springerlink.com/content/3g043158m382444 (retrieved Nov. 9, 2007).

Chen, G., Gully, S. M., \& Eden, D. (2001). Validation of a new general self-efficacy scale. Organizational Research Methods, 4(1), 62-83.

Choi, J., Lee, J.H., \& Kim, B. (2019). How does learner-centered education affect teacher self-efficacy? The case of project-based learning in Korea. Teaching and Teacher Education, 85(1), 45-57.

Christian, B. J. (2017). Primary pre-service teachers' perceptions of course related factors that enhance instructional self-efficacy. Australian Journal of Teacher Education, 42(2), 14-27.

Indráková, M. (2011). Rozdíly mezi českými a americkými studenty ve vnímání času v souvislosti s teorií vnímané vlastní účinnosti. Diplomová práce. Olomouc: UP.

Irvine, J. (2018). A framework for comparing theories related to motivation in education. Research in Higher Education Journal, 35, 1-30.

Jamil, F. M., Downer, J. T., \& Pianta, R. C. (2012) Association of pre-service teachers' performance, personality, and belief with teacher self-efficacy at program completion. Teacher Education Quarterly, Fall, 119-138. 
Janík, T., \& Havel, J. (2005) Pedagogická praxe a profesní rozvoj studentů. Brno: PedF MU.

Janík, T. et al. (2002). Úloha fakultního cvičného učitele a fakultní cvičné školy v př́pravě budoucího učitele. Brno: MSD.

Janoušek, J. (2006). Aspirační úroveň, výkonový motiv a vnímané sebeuplatnění jako psychologické faktory výkonnosti ve společenských podmínkách In: Pražské sociálně vědní studie - Psychologická řada PSY-005. Praha: FSV UK; 1-14.

Janoušek, J. (1992). Sociálně kognitivní teorie Alberta Bandury. Československá psychologie, 36(5), 385-398.

Ježek, S. et al. (2006). Základní pojmy z metodologie psychologie. Brno: FSS MU.

Jeon, H. (2018). Teacher efficacy research in a global context. In Akiba, M., LeTendre, G. (Eds.), International Handbook of Teacher Quality and Policy. New York: Taylor and Francis, 414-429.

Kamali, M., Raudenbush, S. W., \& Bhumirat, C. (1992). Predictors and consequences of primary teachers' sense of efficacy and students' perceptions of teaching quality in Thailand. International Journal of Educational Research, 17(2).

Kasáčová, B. (2005). Reflexívna výučba a reflexia v učitel'skej príprave. Banská Bystrica: PF UMB.

Kim, H. \& Cho, Y. (2014). Pre-service teachers' motivation, sense of teaching efficacy, and expectation of reality shock. Asia-Pacific Journal of Teacher Education, 42(1), 67-81.

Klassen, R. M., Tze, V. M., \& Betts, S. M. et al. (2011). Teacher efficacy research 1998-2009: Signs of progress or unfulfilled promise? Educational Psychology Review, 23(1), 21-43.

Kline, P. (2000). Handbook of psychological testing. Second edition. London: Routlage. Korthagen, F. A. J., Kessels, J., Koster, B., Lagerwerf, B., \& Wubbels, T. (2011) Jak spojit praxi s teorií: Didaktika realistického vzdělávání učitelů. Brno: Paido.

Kokkinos, C.M., Panagopoulou, P., \& Tsolakidou, I. et al. (2015) Coping with bullying and victimisation among preadolescents: the moderating effects of self-efficacy. Emotional and Behavioural Difficulties, 20(2), 205-222.

Krueger, R. A. (1998). Focus groups: a practical guide for applied research. Newbury Park: Sage.

Křivohlavý, J., Schwarzer, R., \& Jerusalem, M. (1993). Česká adaptace General self-efficacy scale. Retrieved from http://userpage.fu-berlin.de/ health/czec.htm. Kukul, V., \& Karataș, S. (2019). Computational Thinking Self-Efficacy Scale: Development, validity and reliability. Informatics in Education, 2019, 18(1), 151-164.

Larson, K., Greders-Schuck, N., B., \& AllenL, B. L. (2004). Can You Call It a Focus Group? Ames, Iowa: 2004. Iowa State University Extension. http://www.extension.iastate.edu/Publications/PM1969A.pdf. 
Lee, W. C., Chen, V.D., \& Wang, L.Y. (2017). A review of research on teacher efficacy beliefs in the learner-centred pedagogy context: Themes, trends and issues. Asia Pacific Educational Review, 18(4), 559-572.

Linke, M. (2013). Reflexe Self-efficacy u začínajících studentů učitelství. In Wiegerová, A. Fórum mladých výzkumníků II. Zlín: Univerzita Tomáše Bati ve Zlíně, Fakulta humanitních studií, 2013.

Linke, M. (2014). Self-efficacy v procesu stávání se učitelem (se zaměřením na začínající studenty učitelství). Bakalářská práce, Hradec Králové: Univerzita Hradec Králové. Fakulta přírodovědecká. S. 41. Vedoucí práce doc. PhDr. T. Svatoš, Ph.D. Linke, M. (2016). Self-efficacy a budoucí učitelé (pohledem kvalitativní a kvantitativní metodologie). Diplomová práce, Hradec Králové: Univerzita Hradec Králové. Fakulta pedagogická. S. 120. Vedoucí práce doc. PhDr. T. Svatoš, Ph.D.

Lindseth, A. \& Norberg, A. (2004). A phenomenological hermeneutical method for researching lived experience. Scandinavian Journal of Caring Sciences. 18(2), 145-153.

Lippke, S. (2017). Self-Efficacy Theory. In Zeigler-Hill, V., \& Shackelford, T.K. (Eds.) Encyclopedia of Personality and Individual Differences. Cham: Springer international Publishing, 1-6. Dostupné na: https://link.springer.com/content/pdf/1 0.1007\%2F978-3-319-28099-8 1167-1.pdf.

Lukášová-Kantorková, H. (2003). Učitelská profese v primárním vzdělávání a pedagogická př́prava učitelů (teorie, výzkum, praxe). Ostrava: PdF OU.

Lukášová, H. (2015). Učitelské sebepojetí a jeho zkoumání. Zlín: FHS UTB.

Luszczynska, A., Scholz, U., \& Schwarzer, R. (2005). The general self-efficacy scale: multicultural validation studies. The journal of psychology, 139(5), 439-457.

Mareš, J. (2013). Pedagogická psychologie. Praha: Portál, 702 s.

Marsh, H.W., Pekrun, R., \& Parker, P.D. et al. (2019). The murky distinction between self-concept and self-efficacy: Beware of lurking jingle-jangle fallacies. Journal of Educational Psychology, 111(2), 331-353.

Majerčíková, J. et al. (2012). Profesijná zdatnost' (self-efficacy) študnetov učitelstva a učitelov spoolupracovat's rodičmi. Bratislava: Univerzita Komenského, s. 136. Majerčíková, J., \& Syslová, Z. (2014). Profesní zdatnost učitelek pro spolupráci s rodiči. Situace v českých a slovenských mateřských školách. In Syslová, Z., \& Rodová, V. (eds.), Předškolní vzdělávanív teorii a praxi (124-135). Brno: MU. Majerčíková, J., \& Gavora, P. (2013). Vnímaná zdatnost' (self-efficacy) učitel'a spolupracovat' s rodičmi: Konštrukcia výskumného nástroja. Pedagogika, 68(2), 128-146.

Mareš, J., \& Gavora, P. (1999). Anglicko-český pedagogický slovník. Praha: Portál. Mareš, J. et al. (1996). Učitelovo pojetí výuky. Brno: CDVU MU.

Mareš, J. (2013). Pedagogická psychologie. Praha: Portál. 
Melichar, M. (2005). Focus groups. Praha: Centrum pro výzkum vysokého školství. Miovský, M. (2006). Kvalitativní přístup a metody v psychologickém výzkumu. Praha: Grada, 2006.

Mlynářová, V. (2015). Self-efficacy sportujících dětí. Diplomová práce. Praha: UK, Filozofická fakulta, s. 89.

Morgen, D. L. (2001). Ohniskové skupiny jako metoda kvalitativního výzkumu. 1. vyd. Brno: Psychologický ústav AV, sdružení SCAN.

Morris, D. B., Usher, E. L., \& Chen, J. A. (2017). Reconceptualizing the sources of teaching self-efficacy: A critical review of emerging literature. Educational Psychology Review, 29(4), 795-833.

Multon, K. D., Brown, S. D., \& Lent, R. W. (1991). Relation of self-efficacy beliefs to academic outcomes: A meta-analytic investigation. Journal of Counseling Psychology, 38(1), 30-38.

Nakonečný, M. (1996). Motivace lidského chování. Praha: Academia.

Nezvalová, D. (2000). Reflexe v pregraduální př́pravě učitelu․ Olomouc: PdF UJEP. Nielsen, J. (1997). The Use and Misuse of Focus Groups. 1997. Dostupné na: http:// www.useit.com/papers/focusgroups.html.org/10.1037//0033-2909.127.3.376. Nikolopoulou, K., \& Gialamas, V. (2015). ICT and play in preschool: early childhood teachers' beliefs and confidence. International Journal of Early Years Education. 23(4), 409-425. DOI: 10.1080/09669760.2015.1078727.

Nyman, J., Parisod, H., \& Axelin, A. et al. (2019). Finnish adolescents' self-efficacy in peer interactions: a critical incident study. Health Promotion International, 34(5), 961-969.

Ozan, C., Gundoglu, K., \& Celkan, H. Y. (2012). A Study on the University Students' Self-Regulated Learning Strategies Skills and Self-Efficacy Perceptions in Terms of Different Variables. Procedia - Social and Behavioral Sciences, 46, 1806-1811.

Pajares, F. (2002) Self-efficacy beliefs in academic contexts: An outline. (on-line) Dostupné na: http://des.emory.edu/mfp/efftalk.html.

Pajares, F. (1996). Self-efficacy beliefs in academic settings. Review of Educational Research, 66(4), 543-578.

Pajares, F. (2007). Overview of social cognitive theory and of self-efficacy. Dostupné na: $\underline{\text { www.des.emory.edu/mfp/effhtml. }}$.

Patton, M. Q. (2002). Qualitative Research and Evaluation Methods. 3. vyd. London: Sage Publ.

Park, S. (2016). Development and validation of a Crisis Self-Efficacy Scale (Doctoral Dissertation). Knoxville: University of Tennessee, 143.

Pepper, D., Hodgen, J., \& Lamesoo, K. et al. (2018). Think aloud: using cognitive interviewing to validate the PISA assessment of student self-efficacy in mathematics. International Journal of Research \& Method in Education, 41(1), 3-16. 
Pelikán, J. (1998). Základy empirického výzkumu pedagogických jevů. Praha: Karolinum.

Pendergast, D., Garvis, S., \& Keogh, J. (2011) Pre-Service Student-Teacher Self-Efficacy Beliefs: An Insight Into the Making of Teachers. Australian Journal of Teacher Education, 36.

Píšová, M. (2005). Klinický rok: procesy profesního rozvoje studentů učitelství a jejich podpora. Pardubice: Univerzita Pardubice, Fakulta humanitních studí́.

Podell, D., \& Soodak, L. (1993). Teacher efficacy and bias in special education referrals. Journal of Educational Research, 86, 247-253.

Poledňová, E. (2006). Výkonová motivace v prostředí školy - souvislosti se sebepojetím a utvářením sociálních vztahů. Vztahy v dospívání. Brno: Barrister \& Principal.

Průcha, J. (2002). Učitel - současné poznatky o profesi. Praha: Portál.

Průcha, J. (eds.), (2009). Pedagogická encyklopedie. Praha: Portál.

Průcha, J., Walterová, E., \& Mareš, J. (2001). Pedagogický slovník. 3. rozšířené a aktualizované vydání. Praha: Portál.

Punch, K. F. (2008). Základy kvantitativního šetření. Praha: Portál.

Pustinová, J. (2019). Self-efficacy u pracovníků v pomáhajících profesích. Diplomová práce. Brno: MU, Filozofická fakulta.

Redmond, B.F., \& Slaugenhoup, E.L. (2016). Self-Efficacy and Social Cognitive Theories. Dostupné na: https://wikispaces.psu.edu/display/PSYCH484/7.+Self-Efficacy tand+Social+Cognitive+Theories.

Reeve, J. (2014). Understanding motivation and emotion. New York: John Wiley.

Riggs, I. M., \& Enochs, L. G. (1990). Toward the development of an elementary teacher's science teaching efficacy belief instrument. Science \& Education, 74, 625-637.

Ross, J., \& Bruce, C. (2007). Professional development effects on teacher efficacy: Results of randomised field trial. The Journal of Educational Research, 101(1), 50-60.

Ross, J. A., \& Gray, P. (2006). Transformational leadership and teacher commitment to organizational values: The mediating effects of collective teacher efficacy. School Effectiveness and School Improvement, 17(2), 179-199.

Rotter, J. B. (1966). Generalized expectancies for internal versus external control of reinforcement. Psychological Monographs, 80(1), 1-28.

Roy, J., \& Robichaud, F. (2016). The shock of reality of new nurses. Recherche en Soins Infirmiers, 127, 82-90.

Ryan, R., \& Deci, E. (2000). Intrinsic and extrinsic motivations: Classic definitions and new directions. Contemporary Educational Psychology, 25(1), 54-67. 
Ryang, D. (2012). Exploratory analysis of Korean elementary pre-service teachers' mathematics teaching efficacy beliefs. International Electronic Journal of Mathematics Education, 2, 45-61.

Seo, S., \& Moon, H. (2013). A comparison study of teaching efficacy in pre-service teachers in Korean early childhood education and care (ECEC). Asia-Pacific Journal of Teacher Education, 41(4), 363-373. DOI: 10.1080/1359866X.2013.787394.

Sharma, U., Loreman, T., \& Forlin, C. (2012). Measuring teacher efficacy to implement inclusive practices. Journal of Research in Special Educational Needs, 12(1), 12-21.

Shavelson, R.J., Hubner, J.J., \& Stanton, G.C. (1976). Self-concept: Validation of construct interpretations. Review of Educational Research, 46(3), 407-441.

Schüller, E.M., Birnbaum, L., \& Kröner, S. (2016). What makes elementary school students read in their leisure time? Development of a comprehensive questionnaire. Reading Research Quarterly, 52(2), 161-175.

Schunk, D. H., \& DiBenedetto, M.K. (2020). Motivation and social cognitive theory. Contemporary Educational Psychology, 60. Dostupné na: https://doi.org/10.1016/i. cedpsych.2019.101832.

Schunk, D. H. (1991). Self-efficacy and academic motivation. Educational Psychologist, 26, 207-231.

Schvarzer, R., \& Jerusalem, M. (1995). Generalized Self-efficacy scale. In: J. Weinman, S. Wright, \& M. Johnston, Measures in health psychology: A user's portfolio. Casual and control beliefs. Windsor, UK, 35-37.

Silverman, G. (2008). A Comparison between Face-to-Face Focus Groups, Telephone Focus Groups and Online Focus Groups. Dostupné na: http://www.mnav.com/ onlinetablesort.htm.

Skaalvik, E.M., Skaalvik, S. (2007). Dimensions of Teacher Self-Efficacy and Relations With Strain Factors, Perceived Collective Teacher Efficacy, and Teacher Burnout. Journal of Educational Psychology, 99(3), 611-625.

Smetáčková, I., Topková, P., \& Vozková, A. (2017). Vývoj a pilotáž škály učitelské self-efficacy. [Development And Piloting Of Teacher Self-Efficacy Scale]. Lifelong Learning - celoživotní vzdělávání, 7, (2), 26-46.

Smith, A., Choi, N., Fuqua, D., \& Newman, T. (2011). Role Ambiguity as a Moderator of Occupational Selfefficacy and Job Satisfaction. Psychological Reports, 109(1), 243-251. Dostupné na: http://dx.doi.org/10.2466/01.07.21.pr0.109.4.243-251.

Spilková, V., \& Vašutová, J. (ed.) (2008). Učitelská profese v měnících se požadavcích na vzdělání. Praha: PedF UK.

Spilková, V. et al. (2004). Současné proměny vzdělávání učitelů. Brno: Paido.

Spilková, V. (2010). Evropské přístupy k pojetí kvality učitele - optikou formálních dokumentů. Pedagogika, 60(3-4), 70-80. 
Spilková, V., Tomková, A., Mazáčová, N., \& Kargerová, J. (2015). Klinická škola a její role ve vzdělávání učitelů. Praha: Retida spol. s.r.o.

Stokking, K., Leenders, F., De Jong, J., \& Van Tartwijk, K. (2003). From student to teacher: Reducing practice shock and early dropout in the teaching profession. European Journal of Teacher Education, 26(3), 329-350.

Strouhal, M. (ed.). (2016). Učit se být učitelem. Praha: Univerzita Karlova.

Strauss, A. L., \& Corbin, J. M. (1999). Základy kvalitativního výzkumu: postupy a techniky metody zakotvené teorie. Boskovice: Albert.

Strevaerd, D. W., \& Shamdasani, P. N. (1990). Focus groups: theory and practice. Newbury Park: Sage.

Southwick, S.M., Bonanno, G.A., \& Masten, A.S. et al. (2014). Resilience definitions, theory, and challenges: interdisciplinary perspectives. European Journal of Psychotraumatology, 5, 25338. Dostupné na: https://www.ncbi.nlm.nih.gov/ pmc/articles/PMC4185134/pdf/EJPT-5-25338.pdf.

Suchodoletz, A. V., Jamil, F.M., \& Larsen, R.A. et al. (2018). Personal and contextual factors associated with growth in preschool teachers' self-efficacy beliefs during a longitudinal professional development study. Teaching and Teacher Education, 75, 278-289.

Svatoš, T. (2008). Procedura focus group ve výzkumné praxi (na př́íkladu výzkumu kvality života). In Svatoš, T., Doležalová, J. (eds). Pedagogický výzkum jako podpora proměny současné školy. Sborník sdělení z 16. konference České asociace pedagogického výzkumu. Hradec Králové: Gaudeamus, 141-156.

Svatoš, T. (2010). Metoda focus group - příklad kvalitativní metodologie. Pedagogická revue, 62(1-2), 23-41.

Svatoš, T. (2012). Začínající studenti učitelství a self-efficcy. In Wiegerová, A. a kol. (2012) Self Efficacy (osobně vnímaná zdatnost'v edukačných súvislostiach). SPN: Bratislava, 84-104.

Svatoš, T. (2013). A student teacher on the pathway to teaching profession: Reviewing research and proposing model. Pedagogická orientace, 23(6), 786-809.

Svatoš, T., \& Švarcová, E. (2007). Žákovské prekoncepty pojmu „kvalita života“. In: KIPS, M., Koldeová, L. (eds.) Výchova, škola, spoločnost' - minulost'a súčasnost'. Bratislava: Univerzita Komenského, 626-636.

Šulová, L. (2004). Děti nastupují do mateřské školy. Informatorium 3 - 8.

Švaříček, R. (2011). Zlomové události při utváření profesní identity učitele. Pedagogika.sk, 2(4), 247-274.

Švaříček, R., Šed'ová, K. (2007). Kvalitativní výzkum v pedagogických vědách. Praha: Portál.

Tschannen-Moran, M., Hoy, A.W., \& Hoy, W. K. (1998). Teacher efficacy: Its meaning and measure. Review of Educational Research, 68(2), 202-248. 
Tschannen-Moran, M., \& Hoy, A.W. (2001). Teacher efficacy: Capturing an elusive construct. Teaching and Teacher Education. 17(7), 783-805.

Urbánek, T., \& Čermák, I. (1996). Self-efficacy dětí ve školní činnosti. Sborník příspěvků z konference k nedožitým 90. narozeninám prof. PhDr. Roberta Konečného. CSc. Brno.

Van Dinther, M., Dochy, F., \& Segers, M. (2011). Factors affecting students' self-efficacy in higher education. Educational Research Review, 6(2), 95-108.

Vašutová, J. (2008). Vzděláváme budoucí učitele: nové přístupy k pedagogicko-psychologické př́ípravě učitelü. Praha: UK.

Veenman, S. (1984). Perceived problems of beginning teachers. Review of Educational Research, 54, 143-178.

Versland, T.M., \& Erickson, J.L. (2017). Leading by example: A case study of the influence of principal self-efficacy on collective efficacy. Cogent Education, 4(1), 1-17. Dostupné na: http://dx.doi.org/10.1080/2331186X.2017.1286765.

Vieluf, S., Kunter, M., \& Van de Vijver, F.J. (2013). Teacher self-efficacy in cross-national perspective. Teaching and Teacher Education, 35(1), 92-103.

Vozková, A. (2014). Self-efficacy v matematice u žáků a žákyň prvního stupně ZŠ. Bakalářská práce. Praha: UK.

Vrieling, E. M., Bastiaens, T. J., \& Stijnen, S. (2010). Process-oriented design principles for promoting self-regulated learning in primary teacher education. International Journal of Educational Research, 4-5, 141-150.

Vozková, A. (2018). Kolektivní učitelská self-efficacy. E-psychologie, 12(4), 47-60. Výrost, J. (1989). Sociálno-psychologický výskum postojov. Bratislava: Veda, 344 s. Wenner, G. (2001). Science and mathematics efficacy beliefs held by practicing and prospective teachers: a five year perspective. Journal of Science Education and Technology, 10, 181-187.

Wiegerová, A. et al. (2012). Self-efficacy: (osobne vnímaná zdatnost') v edukačných súvislostiach. Bratislava: Slovenské pedagogické nakladatel'stvo.

Wiegerová, A., \& Gavora, P. (2014). Proč chci být učitelkou mateřské školy? Pohled kvalitativního výzkumu. Pedagogická orientace, 24(4), 510-534.

Wiegerová, A. et al. (2015). Profesionalizace učitele mateřské školy z pohledu reformy kurikula. Zlín: FHS UTB.

Wiegerová, A. (2016). The Careers of young Czech University teachers. Zlín: Nakladatelství UTB.

Wood, R., \& Bandura, A. (1989). Impact of conceptions of ability on self-regulatory mechanisms and complex decision making. Journal of Personality and Social Psychology, 56(3), 407-415. 
Woolfolk Hoy, A., \& Spero, R. B. (2005). Changes in teacher efficacy during the early years of teaching: A comparison of four measures. Teaching and Teacher Education, 21(4), 343-356.

Zimmerman, B. J. (2000). Self-efficacy: an essential motive to learn. Contemporary Educational Psychology, 25(1), 82-91. Retrieved from: http://dx.doi.org/10.1006/ ceps.1999.1016.

Zimmerman, B. J. (1995). Self-efficacy and educational development. In Bandura, A. (Ed.) Self-efficacy in changing societies. New York: Cambridge University Press, 202-231.

\section{Internetové zdroje:}

http://www.webcredible.co.uk/

www.exnet.iastate.edu

http://faculty.chass.ncsu.edu/garson/PA765/index.shtml

http://www.tc.umn.edu/ rkrueger/index.html 


\section{REJSTŘÍK}

A

Abbott, D. H. 34, 115

Adair, J.G. 116

Akiba, M. 121

AllenL, B. L. 121

Aloe, A. M. 39, 115

Altan, M. Z. 58, 115

Amo, L. C. 39, 115

Ashton, P. 68, 115

Axboe, M.K. 30, 115

Axelin, A. 34, 123

Azar, A. 115

B

Balaštíková, V. 115

Bandura, A. 13, 14, 15, 16, 17, 18, 19, 20 ,

$21,23,25,26,28,29,35,37,40,64,65$, $66,68,69,81,90,97,104,106,111,113$, $115,116,121,127,128$

Barbaranelli, C. 117

Barry, N. H. 33, 116

Bastiaens, T. J. 45, 127

Bélanger, D. 116

Bergman, M. 15, 116

Bergman, Z. 15, 116
Bernadowski, C. 34, 117

Best, R. 32, 118

Betts, S. M. 37, 121

Bhumirat, C. 45, 121

Bilz, L. 32, 118

Birnbaum, L. 125

Blatný, M. 115

Bonanno, G.A. 126

Boone, W. 90, 117

Bos, W. 25, 119

Boujut, E. 28, 116

Bowron, R. 28, 117

Bravená, N. 119

Brouwers, A. 64, 65, 116, 118

Brown, S. D. 25, 123

Bruce, C. 62, 124

Buhr, D. 68, 115

Bull, T. 67, 117

Bunnin, N. 117

Busby, R. 28, 117

C

Cakiroglu, E. 90, 117

Cakiroglu, J. 90, 117

Caprara, G.V. 117 
Celkan, H. Y. 45, 123

Cohen, J. 117

Cooney, J. 64, 65, 117

Corbin, J. M. 47, 95, 96, 126

Cousins, J. B. 117

Crocker, L. 68, 115

$\check{\mathbf{C}}$

Čermák, I. 117, 127

D

Deci, E. 22, 124

Deeemer, S. 117

De Jong, J. 126

Del Greco, R. 34, 117

Dembo, M. H. 62, 65, 90, 119

Demirci, F. 31, 117

Denzine, G. 64, 65, 117

DeVellis, V. R. 84, 117

DiBenedetto, M.K. 14, 125

Dick, B. 74, 117

Dicke, T. 57, 117

Dion, K.L. 116

Dochy, F. 45, 127

Downer, J. T. 120

Durham, S. 33, 116

Dytrtová, R. 117

E

Eden, D. 117, 120

Edwards, M. C. 120

Elling, J. 117

Enochs, L. 118

Enochs, L. G. 124

Epstein, J. L. 67, 118

Erickson, J.L. 35, 127

Erlich, R.J. 28, 118

Evers, W. J. G. 118
F

Feldt, R. C. 118

Ferjenčík, J. 118

Fischer, S.M. 32, 118

Flanders, N. A. 118

Forlin, C. 125

Fox, M. C. 32, 118

Fuqua, D. 125

G

Garvis, S. 45, 124

Gau, B.H. 80, 118

Gavora, P. 17, 45, 57, 65, 67, 72, 90, 118, 122, 127

Gebauer, M. M. 25, 119

Geoghegan, D. 119

Geoghegan, N. 119

Gialamas, V. 80, 123

Gibson, S. 62, 64, 65, 79, 90, 119

Gist, M.E. 34, 119

Glackin, M. 29, 119

Gore, P. A. 119

Gray, P. 124

Greders-Schuck, N., B. 121

Greger, D. 64, 119

Gully, S. M. 120

Gundoglu, K. 123

Guo, Y. 43, 90, 119

Guskey, T. R. 65, 119

H

Hamill, S. K. 23, 119

Hastings, P. 33, 119

Havel, J. 121

Haverback, H. R. 119

Hebronová, V. 46, 119

Hejlová, H. 119

Hemphill, J. F. 119

Hendl, J. 77, 119 
Henson, R. K. 37, 62, 120

Hodgen, J. 32, 123

Hofstede, G. 41, 120

Hofstede, G. J. 41, 120

Hohenstein, J. 29, 119

Horaková-Hoskovcová, S. 120

Hoy, A.W. 27, 40, 64, 126, 127

Hoy, W. K. 27, 126

Hubner, J.J. 20, 125

Hughes, G. 120

Huinker, D. 118

Hung, Ch.-Ch. 80, 118

Ch

Chan, D. W. 45, 120

Chang, E.C. 120

Charalambous, Y. 90, 120

Chen, G. 38, 120

Chen, J. A. 27, 123

Chen, V.D. 38, 122

Choi, J. 27, 120

Cho, Y. 57, 121

Christensenk, S. 115

Christian, B. J. 26, 120

I

Indráková, M. 46, 120

Ingram, R. 28, 117

Irvine, J. 22, 120

J

Jamil, F. M. 90, 120, 126

Janík, T. 55, 57, 121

Janoušek, J. 13, 17, 18, 121

Jeon, H. 40, 41, 42, 121

Jerusalem, M. 121, 125

Ježek, S. 70, 121

Johnston, M. 125

Justice, L. M. 43, 119
$\mathbf{K}$

Kamali, M. 45, 121

Karataş, S. 32, 121

Kargerová, J. 57, 126

Kasáčová, B. 55, 121

Keogh, J. 45, 124

Kessels, J. 121

Kim 27, 57

Kim, B. 120

Kim, H. 121

Klassen, R. M. 37, 121

Kline, P. 82, 121

Kofoed, P.E. 115

Kohoutek, T. 115

Kokkinos, C.M. 26, 121

Koldeová, L. 126

Korthagen, F. A. J. 121

Koster, B. 121

Krhutová, M. 55, 117

Kröner, S. 125

Krueger, R. A. 73, 121

Křivohlavý, J. 121

Kukul, V. 32, 121

Kunter, M. 41, 127

Kyriakides, L. 120

L

Lagerwerf, B. 121

Lamesoo, K. 32, 123

Larsen, R.A. 126

Larson, K. 74, 121

Lee 27, 38

Lee, J.H. 120

Leenders, F. 126

Lee, W. C. 122

Lent, R. W. 25, 123

LeTendre 121

Leutner, D. 117

Lindseth, A. 122 
Linke, M. 9, 47, 91, 97, 98, 105, 122

Lippke, S. 13, 18, 122

Loreman, T. 125

Lukášová, H. 9,122

Lukášová-Kantorková, H. 55, 122

Luszczynska, A. 122

M

Majerčíková, J. 45, 67, 122

Malone, P. S. 117

Mareš, J. 17, 57, 64, 100, 122, 124

Marsh, H.W. 21, 122

Masten, A.S. 126

Mazáčová, N. 56, 57, 126

McElvany, N. 25, 119

McKenzie, R. 64, 65, 117

Melichar, M. 123

Minke, K. 64, 65, 117

Miovský, M. 123

Mlynářová, V. 46, 123

Moon, H. 80, 90, 125

Morgen, D. L. 123

Morris, D. B. 27, 123

Multon 25

Multon, K. D. 123

N

Nakonečný, M. 17, 123

Newman, T. 125

Nezvalová, D. 55, 123

Nielsen, J. 71, 123

Nikolopoulou, K. 80, 123

Norberg, A. 122

Nyman, J. 34, 123

O

O'Neill, S. 119

Opravilová, E. 119

Ozan, C. 45, 123
Ozyurek 31, 117

$\mathbf{P}$

Pajares, F. 64, 116, 123

Palomares, E. A. 28, 116

Panagopoulou, P. 26, 121

Parault, S. J. 119

Parisod, H. 34, 123

Parker, P.D. 21, 122

Parker, S. 34, 117

Park, S. 31, 123

Passaro, P. D. 65, 119

Patton, M. Q. 123

Pekrun, R. 21, 122

Pelikán, J. 71, 124

Pendergast, D. 45, 124

Pepper, D. 32, 123

Philippiou, G. 90, 120

Pianta, R. C. 120

Píšová, M. 55, 124

Podell, D. 124

Poledňová, E. 124

Popa-Roch, M. 28, 116

Průcha, J. 9, 55, 100, 124

Punch, K. F. 124

Pustinová, J. 47, 124

$\mathbf{R}$

Raudenbush, S. W. 45, 121

Redmond, B.F. 18, 124

Reeve, J. 19, 124

Riggs, I. M. 64, 124

Riley, M. M. 120

Robichaud, F. 124

Rodová, V. 122

Ross, J. A. 62, 124

Rotter, J. B 64, 90, 124

Roy, J. 124

Russ-Eft, D. 28, 118 
Ryang, D. 125

Ryan, R. 22, 124

S

Saglamel, H. 58, 115

Salinas, K. L. 67, 118

Sanna, L. 120

Sawyer, B. 43, 119

Segers, M. 45, 127

Seo, S. 80, 90, 125

Shackelford, T.K. 122

Shamdasani, P. N. 126

Shanahan, M. E. 39, 115

Sharma, U. 30, 125

Shavelson, R.J. 20, 125

Schmeck, A. 117

Scholz, U. 122

Schüller, E.M. 31, 125

Schunk, D. H. 14, 125

Schvarzer, R. 125

Schwarzer, R. 21, 121, 122

Silverman, G. 75, 125

Skaalvik, E.M. 40, 125

Skaalvik, S. 40, 125

Slaugenhoup, E.L. 18, 124

Smetáčková, I. 125

Smith, A. 125

Smith, P. L. 118

Soodak, L. 124

Southwick, S.M. 23, 126

Spero, R. B. 90, 128

Spilková, V. 55, 57, 125, 126

Stanton, G.C. 20, 125

Steca, P. 117

Stijnen, S. 45, 127

Stokking, K. 126

Strauss, A. L. 47, 95, 96, 126

Strevaerd, D. W. 126

Strouhal, M. 126
Suchodoletz, A. V. 126

Svatoš, T. 52, 53, 54, 78, 95, 122, 126

Syslová, Z. 122

$\check{\mathbf{S}}$

Šed'ová, K. 77, 126

Šulová, L. 126

Švarcová, E. 95, 126

Švaříček, R. 57, 77, 126

T

Thather, A. 15, 116

Thornburg, A. M. 120

Tomic, W. 64, 65, 116, 118

Tomková, A. 57, 126

Tompkins, V. 119

Topková, P. 125

Tschannen-Moran, M. 27, 40, 64, 66, 68, 79, 87, 90, 126, 127

Tsolakidou, I. 26, 121

Tze, V. M. 37, 121

U

Uhlírová, J. 119

Urbánek, T. 55, 117, 127

Urdan, T. 116

Usher, E. L. 27, 123

V

Van de Vijver, F.J. 41, 127

Van Dinther, M. 45, 127

Van Tartwijk, K. 126

Vašutová, J. 55, 125, 127

Veenman, S. 127

Versland, T.M. 35, 127

Vieluf, S. 41, 127

Vozková, A. 20, 46, 125, 127

Vrieling, E. M. 45, 127

Výrost, J. 18, 21, 127 
W

Walker, C. A. 117

Walterová, E. 100, 124

Wang, L.Y. 38, 122

Weinman, J. 125

Wenner 45, 127

White, R. 119

Wiegerová, A. 11, 57, 111, 113, 118, 122,

126, 127

Wood, R. 127

Woolfolk Hoy, A. 27, 64, 66, 68, 79, 87,

90, 128

Wright, S. 125

Wubbels, T. 121

$\mathbf{Z}$

Zeigler-Hill, V. 122

Zimmerman, B. J. 25, 128

Zumberg, K. M. 120 

Univerzita Tomáše Bati
Fakulta humanitních studii

FAKULTA HUMANITNICH STUDIII/EDICE PEDAGOGIKA

(C) Peter Gavora, Jiř́i Mareš, Tomáš Svatoš, Adriana Wiegerová

Recenzenti: prof. PhDr. Hana Lukášová, CSc. prof. PhDr. Jan Průcha, DrSc. Dr.h.c. prof. PhDr. Miron Zelina, DrSc.

Jazyková korektura: Mgr. Jana Kasáčková, Ph.D.

Zodpovědný redaktor: Mgr. Pavel Holík

Kontrola literatury: Bc. Alžbeta Kopačíková

Název: Self efficacy v edukačních souvislostech II.

Autoři: Peter Gavora, Jiří Mareš, Tomáš Svatoš, Adriana Wiegerová

Grafická úprava a sazba: Nakladatelství UTB, www.nakladatelstvi.utb.cz

Foto na obálce: www.shutterstock.com

Vydavatel: Univerzita Tomáše Bati ve Zlíně

Pořadí vydání: První

Rok vydání: 2020

Vydáno elektronicky

https://doi.org/10.7441/978-80-7454-949-6

ISBN 978-80-7454-949-6 

Z posudků...

Tato kniha je skvělým př́íkladem toho, jak může být popsáno, jasně vysvětleno a kriticky zhodnoceno důležité vědecké téma. Problematika self efficacy, tj. subjektem vnímaná vlastní zdatnost, je v českém a slovenském prostředí skutečně novým okruhem zkoumání a v oblasti pedagogiky donedávna málo známým a nedoceňovaným. Je zásluhou zlínské skupiny, iniciované zejména slovenskými kolegy prof. P. Gavorou a doc. A. Wiegerovou, že u nás tato problematika začala vstupovat do zorného pole pedagogické vědy. Ve spolupráci s renomovaným psychologem prof. J. Marešem a významným hradeckým pedagogem doc. T. Svatošem tak vzniklo dílo mimořádné kvality. Kniha je po obsahové stránce kompaktní, nebot' poskytuje vhled do vývoje problematiky, do jejího současného stavu i do možností dalších potřebných výzkumů v této oblasti. K pozitivním rysům patří také terminologické řešení, tj. důsledné užívání asi nejvhodnějšího termínu „vnímaná vlastní zdatnost“ namísto různých ekvivalentů původního anglického termínu, jak se s nimi v české a slovenské literatuře setkáváme.

prof. PhDr. Jan Průcha, DrSc.

Je nielen odborne, ale aj l'udsky zaujímavé sledovat' zmeny v myslení, posun v poznaní odborníkov na istú problematiku - v tomto prípade na fenomén self efficacy. Posudzoval som ich prácu z roku 2012, kde podnadpis formulovali ako osobné vnímanie zdatnosti v edukačných súvislostiach. Autori predložili na recenzovanie pokračujúci diel, ktorý má vysoké kvality tak, ako ten predchádzajúci. Čo možno nielen ocenit' ale svojím spôsobom aj obdivovat', je štýl prezentácie textov. Sú to zrelí autori, ktorí možno prešli etapami vyjadrovania jednoducho a zle, potom zložito a zle a napokon jednoducho a dobre. Ich jazyk je zrozumitel'ný, zasahujúci podstatu a nechávajúci priestor pre imagináciu. Tejto stručnej múdrosti sa dá azda naučit' len dlhodobou tvorivou praxou a múdrost'ou. Prácu odporúčam do pozornosti, pretože jej prínosom je odborne vysoko spracovaná teoretická čast', ale tá je podporená kvalitnou prezentáciou najnovších výskumov, čo podčiarkuje aj jej metodologický a výskumný charakter. 